UNIVERSIDADE DE SÃO PAULO

INSTITUTO DE BIOCIÊNCIAS

DEPARTAMENTO DE FISIOLOGIA

Nathana Mezzalira

EFEITO DA LUZ E TEMPERATURA SOBRE A EXPRESSÃO DE GENES DO RELÓGIO EM MAMÍFERO: TECIDOS PERIFÉRICOS COMO MODELO DE ESTUDO

EFFECT OF LIGHT AND TEMPERATURE ON THE MAMMALIAN CLOCK GENES EXPRESSION: PERIPHERAL TISSUES AS STUDY MODEL

São Paulo 
Nathana Mezzalira

\title{
EFEITO DA LUZ E TEMPERATURA SOBRE A EXPRESSÃO DE GENES DO RELÓGIO EM MAMÍFERO: TECIDOS PERIFÉRICOS COMO MODELO DE ESTUDO
}

\author{
EFFECT OF LIGHT AND TEMPERATURE ON THE MAMMALIAN \\ CLOCK GENES EXPRESSION: PERIPHERAL TISSUES AS STUDY \\ MODEL
}

\begin{abstract}
Dissertação apresentada ao Instituto de Biociências da Universidade de São Paulo, para a obtenção de Título de Mestre em Ciências, na área de Fisiologia Geral.

Orientador(a): Profa. Dra. Ana Maria de Lauro Castrucci
\end{abstract}

São Paulo 
Autorizo a reprodução e divulgação total ou parcial deste trabalho, por qualquer meio convencional ou eletrônico, para fins de estudo e pesquisa, desde que citada a fonte.

\author{
FICHA CATALOGRÁFICA ELABORADA
}

PELA BIBLIOTECA DO INSTITUTO DE BIOCIÊNCIAS / USP

Mezzalira, Nathana.

Efeito da luz e temperatura sobre a expressão dos genes do relógio em mamífero: tecidos periféricos como modelo de estudo / Nathana Mezzalira; orientadora Ana Maria de Lauro Castrucci. -- São Paulo, 2015.

$107 \mathrm{f}$.

Dissertação (Mestrado) - Instituto de Biociências da Universidade de São Paulo. Departamento de Fisiologia Geral.

1. Canais TRP. 2. Relógios periféricos. 3. B16-F10 Per1:: Luc.

4. Mus musculus. 5. Genes do Relógio. I. Castrucci, Ana Maria de Lauro. II. Universidade de São Paulo. Instituto de Biociências. Departamento de Fisiologia Geral. III. Título. 
Nome: Mezzalira, Nathana

Título: Efeito da Luz e Temperatura Sobre a Expressão de Genes do Relógio em Mamíferos: Tecidos Periféricos como Modelo de Estudo

Dissertação apresentada ao Instituto de Biociências da Universidade de São Paulo para obtenção do título de Mestre em Ciências, na Área de Fisiologia Geral.

Aprovado em:

Banca Examinadora

Prof. Dr. (a):

Instituição:

Julgamento:

Assinatura:

Prof. Dr. (a):

Instituição:

Julgamento:

Assinatura:

Julgamento: Assinatura:

Profa. Dra. Ana Maria de Lauro Castrucci Orientadora 
Dedico esse trabalho aos meus pais, Nelcir e Marli, que sempre me apoiaram e estiveram ao meu lado em todas as batalhas, e ao meu amor, Murilo, pelo incentivo e companheirismo. Saibam que todas as conquistas da minha vida serão para e por vocês. 
"Agradeço todas as dificuldades que enfrentei; não fosse por elas, eu não teria saído do lugar. As facilidades nos impedem de caminhar. Mesmo as críticas nos auxiliam muito."

Chico Xavier

Agradeço primeiramente a Deus por ter iluminado cada passo dado em minha vida. Por abençoar cada escolha e cada conquista. Agradeço por tudo o que até aqui me aconteceu, pois tudo foi feito em nome de Sua vontade.

Agradeço à minha família pelo apoio incondicional ao longo deste processo e de muitos outros da minha vida. Vocês sempre serão o motivo de minhas realizações.

Agradeço ao meu esposo, Murilo, por sempre acreditar em mim, mesmo quando eu não acreditava. Pelo seu amor e apoio em todas as minhas decisões. Você e meus pais são a minha fortaleza.

Agradeço imensamente à minha orientadora Profa. Dra. Ana Maria de Lauro Castrucci pela oportunidade de realizar esse trabalho em seu laboratório, por ter me ensinado fazer ciência com seriedade e ética, pela confiança e por sua amizade.

Agradeço aos amigos e companheiros de laboratório Jenny, Bruno, Assis, Rodrigo, Márcio e especialmente à Nathy, não só por todo suporte e auxílio na construção desse trabalho, mas principalmente, pelo ombro amigo e pelas palavras de amizade e afeto que sempre vieram de você. À Profa. Dra. Maristela Poletini pela disposição, conhecimento e carinho.

Agradeço aos meus amigos pelos momentos de alegria e descontração durante o processo de construção dessa dissertação. Obrigada também por me ouvirem, aconselharem e estarem do meu lado sempre que precisei. 
Agradeço ao Instituto de Biociências e à Universidade de São Paulo pela oportunidade de fazer parte de uma das melhores universidades públicas do país e enriquecer minha carreira.

Agradeço às agências de fomento CNPq e FAPESP (processo 2013/02131-5) pela bolsa de Mestrado concedida e a CAPES, CNPq e FAPESP pelo suporte financeiro.

A todos, muito obrigada! 
"Tenho a impressão de ter sido uma criança brincando à beira-mar, divertindo-me em descobrir uma pedrinha mais lisa ou uma concha mais bonita que as outras, enquanto o imenso oceano da verdade continua misterioso diante de meus olhos". 
O surgimento e a evolução da vida na terra foram possíveis graças ao desenvolvimento de mecanismos temporais precisos capazes de ajustar os processos fisiológicos que ocorriam no interior do organismo com os ciclos ambientais, promovendo assim, ganhos na capacidade adaptativa e reprodutiva dos indivíduos.

Neste contexto, luz e temperatura são as duas pistas temporais mais relevantes para resetar o relógio endógeno e, aparentemente, esses dois zeitgebers trabalham juntos para manter os ritmos circadianos. Uma ampla gama de fotorreceptores e fotopigmentos evoluiu no sentido de perceber com alta sensibilidade a informação fótica fornecida pelo ambiente e, recentemente, foi demonstrado que a detecção de temperatura também pode ser exercida pelos fotopigmentos rodopsina e melanopsina, sendo mediada por canais TRP (Shen et al., 2011). Consideramos as células B16-F10 Perl::Luc como um modelo promissor para o estudo de luz e temperatura em relógios periféricos, uma vez que essa linhagem expressa os dois fotopigmentos apontados com função de termorreceptores em Drosophila. Nossos estudos nos permitiram verificar que a luz não atua como um agente sincronizador nessas células, que se mantiveram em livre curso mesmo após um pulso de $10 \mathrm{~min}$ de luz azul (650 lux). Por outro lado, um pulso de temperatura de $2,5^{\circ}$ $\mathrm{C}$ acima da temperatura de manutenção por $1 \mathrm{~h}$ atuou ajustando a expressão do gene Perl, imprimindo um ritmo circadiano, diferentemente do observado no controle.

Com base nessas informações, hipotetizamos que a informação de luz, percebida via melanopsina na retina de mamíferos, levaria a regulação da temperatura circadiana pelo NSQ, e a temperatura corporal, por sua vez, poderia atuar como uma pista interna para a sincronização dos tecidos periféricos, tendo os canais TRP como mediadores. Para responder esta questão, utilizamos camundongos WT e TrpVI KO submetidos a 
diferentes protocolos de luz e avaliamos a expressão de genes do relógio Per1, Per2, Clock e Bmall e dos canais $\operatorname{TrpVI}$ e $\operatorname{TrpA} 1$ em tecidos periféricos. Identificamos que a glândula suprarrenal, fígado e tecido adiposo marrom possuem uma maquinaria do relógio tipicamente ativa e acreditamos que a oscilação dos genes de relógio observada nesses tecidos é expressiva. Interessantemente, vimos também que o TrpVl, além de ser expresso nos tecidos analisados em animais WT, apresenta uma transcrição rítmica no fígado e tecido adiposo marrom de animais em LD, corroborando nossa hipótese de que canais TRP atuam como mediadores da informação de luz aos tecidos periféricos. Dadas as diferenças encontradas entre os animais WT e TrpVl KO, sugerimos que a presença do canal TRPV1 pode ser essencial, embora seu grau de envolvimento varie de acordo com o tecido. No que diz respeito ao canal TRPA1, encontramos dois resultados que merecem ser destacados. Primeiramente, identificamos no fígado de camundongos TrpVl KO mantidos em LD uma provável compensação da expressão de TrpAl na ausência de $\operatorname{Trp} V 1$ e, curiosamente, que o tecido adiposo marrom não expressa o canal $\operatorname{TrpA1.}$

Considerando os resultados deste trabalho sobre o envolvimento dos canais TRP em resposta à luz e temperatura, acreditamos ter fortalecido nossa hipótese inicial, principalmente após demonstrarmos o papel do canal TRPV1 e que tecidos periféricos são sincronizados por alterações de temperatura.

Palavras-chaves: Luz, temperatura, canais TRP, genes do relógio, B16-F10 Perl::Luc, Mus musculus, relógios periféricos. 
The life emergence and evolution on Earth were made possible by the development of precise temporal mechanisms able to adjust the physiological processes within an organism with environmental cycles, thus promoting gains in the adaptive and reproductive capacity of the individuals.

In this context, light and temperature are the two most relevant time cues to reset the endogenous clock; apparently these two zeitgebers work together to keep the circadian rhythms. A wide variety of photoreceptors and photopigments evolved in order to precisely perceive the photic information provided by the environment, and recently it has been shown that the temperature detection can also be exerted by the photopigments rhodopsin and melanopsin, being mediated by TRP channels (Shen $e t$ al., 2011). We have identified B16-F10 Per1::Luc cells as a promising model for the study of light and temperature effects on peripheral clocks, since this cell line expresses both photopigments pointed as thermoreceptors in Drosophila. Our studies allowed us to demonstrate that light does not act as a synchronizing agent on those cells, which remained in free running after a 10 min pulse of blue light (650 lux). On the other hand, a temperature pulse of $2.5^{\circ} \mathrm{C}$ above the maintenance temperature, for $1 \mathrm{~h}$, adjusted Per 1 gene expression, imprinting a circadian rhythm, which was not observed in the control.

Based on this information, we hypothesized that the light perceived via melanopsin by the mammalian retina would lead to the regulation of the circadian temperature by the $\mathrm{SCN}$, and the body temperature, in turn, could act as an inner cue for the synchronization of the peripheral tissues, having the TRP channels as mediators. To answer this question, we have used WT and TrpVI KO mice under different light protocols and evaluated the expression of clock genes Perl, Per2, Clock and Bmall and 
$\operatorname{Trp} V 1$ and $\operatorname{TrpAl}$ channels in peripheral tissues. We found that the adrenal gland, liver and brown adipose tissue have a typically active clock machinery, and the oscillation of clock genes observed in these tissues is significant. Interestingly, we observed that $\operatorname{TrpV1}$ is expressed in those tissues, and presents a rhythmic transcription in the liver and brown adipose tissue of LD maintained animals, confirming our hypothesis that TRP channels act as mediators of light information to peripheral tissues. In face of the differences between WT and trpV1 KO animals, we suggest that the presence of the TRPV1 channel may be essential, although its degree of involvement may vary according to the tissue. In terms of TRPA1 channel, we found two results that deserve to be highlighted. Firstly, we identified in the liver of TrpV1 KO mice maintained in LD a presumable compensation of $\operatorname{TrpAl}$ expression in the absence of $\operatorname{Trp} V 1$ and, interestingly, the brown adipose tissue does not express $\operatorname{Trp} A 1$ channel.

Considering the findings of this study on the participation of TRP channels in responses to light and temperature, we believe we have strengthened our initial hypothesis, especially after we have demonstrated the role of TRPV1 channel, and that peripheral tissues may be synchronized by temperature changes.

Keywords: Light, temperature, TRP chanels, clock genes, B16-F10 Perl::Luc, Mus musculus, peripheral clocks. 


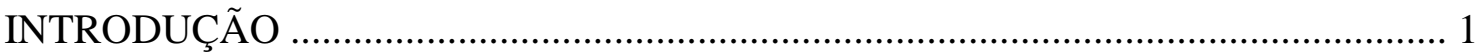

1. A Ritmicidade Biológica e a Organização Temporal dos Organismos ....................... 2

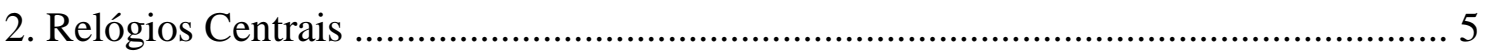

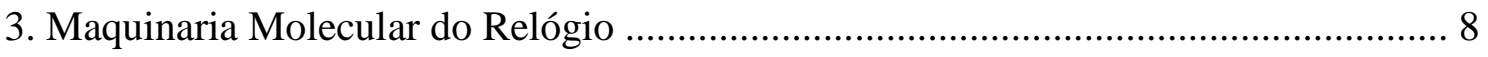

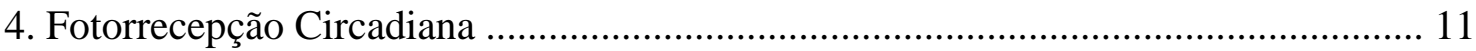

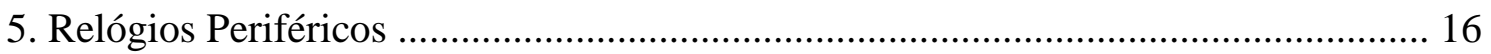

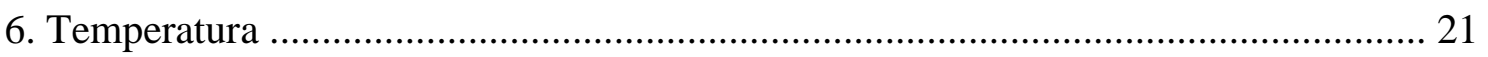

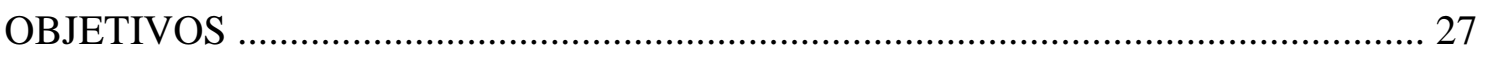

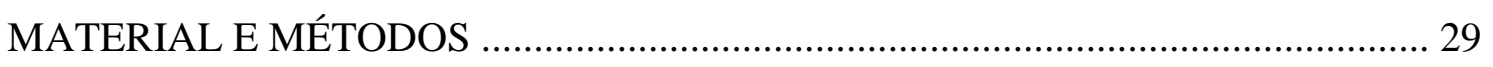

1. Melanoma B16-F10 Per1::Luc de Mus musculus .................................................. 30

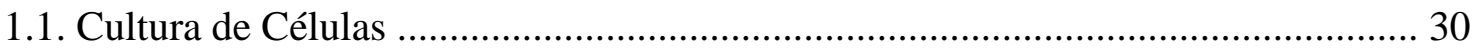

1.2. Efeito do Pulso de Luz ou de Temperatura ....................................................... 30

2. Quantificação Gênica em Glândula Suprarrenal, Fígado e Tecido Adiposo Marrom de Mus musculus Submetidos in Vivo a Diferentes Protocolos de Luz ........................... 31

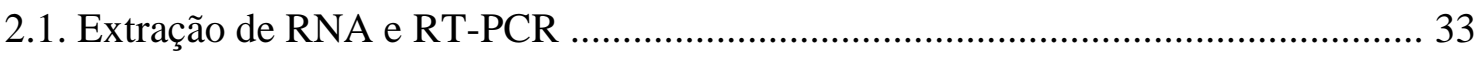

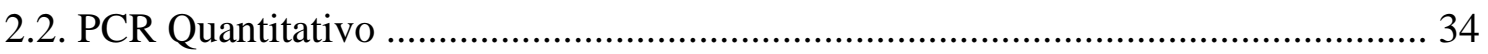



1. Efeito do Pulso de Temperatura em Células B16-F10 Perl::Luc ............................ 40

2. Efeito do Pulso de Luz em Células B16-F10 Per $1:$ Luc .......................................... 42

3. Quantificação Gênica em Glândula Suprarrenal, Fígado e Tecido Adiposo Marrom de Mus musculus Submetidos in vivo a Diferentes Protocolos de Luz ............................ 44

3.1. Expressão dos Genes de Relógio em Glândula Suprarrenal de Mus musculus ..... 45

3.2. Expressão dos Genes de Relógio em Fígado de Mus musculus ............................ 48

3.3. Expressão dos Genes de Relógio em Tecido Adiposo Marrom de Mus musculus 52 
3.4. Expressão dos Canais Trp em Glândula Suprarrenal, Fígado e Tecido Adiposo Marrom de Mus musculus

3.5. Comparação da Expressão dos Genes do Relógio em Glândula Suprarrenal, Fígado e Tecido Adiposo Marrom de Mus musculus 62

3.6. Expressão dos Genes do Relógio e Canais Trp em Glândula Suprarrenal de Mus



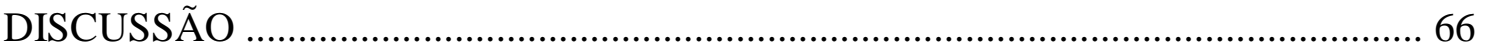

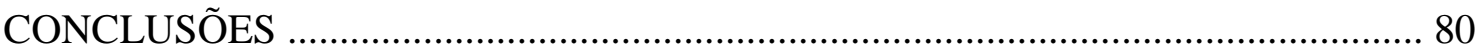

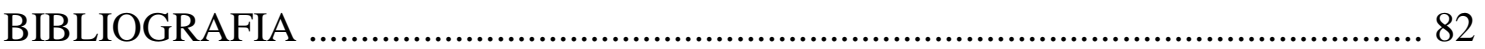




\section{Introdução}

"Aprender é a única coisa de que a mente nunca se cansa, nunca tem medo e

nunca se arrepende."

Leonardo da Vinci 
INTRODUÇÃO

\section{A ritmicidade biológica e a organização temporal dos organismos}

A existência da vida na Terra possui um histórico remoto e rico em mudanças e adaptações ao ambiente, algumas delas, transformações drásticas nas condições de vida que, em última instância, se tornaram responsáveis pela seleção de grande biodiversidade. Algumas das mudanças ambientais persistem de forma cíclica ao longo do tempo, tais como o dia e a noite, oscilações das marés, fases da Lua, estações do ano (Menna-Barreto, 2003).

Os ritmos podem ser considerados os fenômenos mais frequentes em relação à vida, a própria distinção entre a vida e a morte no homem e em muitos animais inclui a ausência de ritmos (ondas cerebrais, batimentos cardíacos, respiração) como sinal de discriminação. A ritmicidade está presente desde os seres vivos de organização mais simples como bactérias e algas unicelulares aos grandes vertebrados, manifestando-se em diferentes tipos de organização, do nível celular ao sistêmico, presente nas várias fases do desenvolvimento, influenciando desde padrões comportamentais a processos fisiológicos (Menna-Barreto, 2003).

A palavra ritmo é de origem grega, rhytmos, significa processo que se repete a intervalos regulares, ou seja, em se tratando de ritmos biológicos podemos entender que é a expressão de um processo que se repete com o mesmo período ao longo do tempo. Os ritmos biológicos manifestam-se em períodos que vão de milissegundos, como os ritmos de disparo de neurônios ou de batimentos do flagelo de espermatozoides, até anos, como o ciclo reprodutivo do bambu chinês (100 anos). Existe uma classificação que se baseia na duração do período: se este varia de 20 a 28 horas, o ritmo se chama circadiano; se apresentar um período inferior a 20 horas, se denomina ultradiano; já se o período for maior que 28 horas, o ritmo é dito infradiano (Marques et al., 2003). 
Embora as observações de fenômenos rítmicos na natureza tenham sido relatadas desde a antiguidade, somente no século XVIII o ritmo biológico começou a ser estudado cientificamente (Foster e Kreitzman, 2004). O francês Jacques d'Ortus Mairan (1678-1771) estudou uma planta do gênero Mimosa, que mantinha suas folhas abertas durante o dia e fechadas durante a noite. Intrigado com aquele comportamento biológico, o astrônomo isolou a planta de qualquer sinal de luz e observou que, mesmo naquela condição de escuro constante, ela continuava a apresentar o movimento de abrir e fechar suas folhas, respectivamente durante o dia e a noite. Chegou a reportar à Academia Real de Ciências da França que "a planta sensitiva percebia o sol sem mesmo vê-lo" (Zordan et al., 2000). No entanto, o experimento que caracterizou o ritmo intrínseco da planta foi realizado no século seguinte (XIX) por De Candole. Desta vez, o botânico suíço submeteu a mesma planta usada por Mairan à condição de iluminação constante e também observou a permanência do movimento de abrir e fechar das folhas. Mas além dessa observação, ele verificou que o período do ritmo era inferior a 24 horas, ou seja, se algum fator geofísico fosse responsável pelo ritmo, o período deveria ser exatamente de 24 horas, qualquer período diferente desse, significaria que ele foi gerado pela própria planta (Foster e Kreitzman, 2004).

A endogenicidade do ritmo confere às espécies a capacidade de antecipação frente às mudanças ambientais cíclicas porque lhes permite a preparação tanto comportamental como fisiológica para o evento que vem a seguir. Dessa forma, todas as alterações rítmicas são determinantes para a sobrevivência do indivíduo e da espécie (Menna-Barreto, 2003).

Ritmos biológicos podem ser entendidos como manifestações claras de organização temporal, organização tal que permite aos organismos ocuparem seu nicho temporal no momento adequado (Pittendrigh, 1993). Sabendo-se que há um sistema de 
temporização próprio dos organismos, no qual relógios internos são responsáveis pelo período de oscilação endógena, surge a pergunta: como os relógios internos se relacionam com as variações do meio externo?

O papel dos ciclos ambientais é o de ajustar o relógio endógeno. Essa sincronização é alcançada através do processo de arrastamento (Pittendrigh, 1981), que consiste nos deslocamentos de fase do ritmo biológico (Marques et al., 2003), ou seja, o ritmo em livre curso (em condições constantes e por isso expressando seu período intrínseco) tem sua fase e frequência ajustadas por um ou mais fatores cíclicos ambientais (Pittendrigh, 1981). Ao fator cíclico ambiental ou pista ambiental, responsável pelo arrastamento, deu-se o nome de zeitgeber (palavra alemã que significa "doador de tempo"). Para a maioria dos organismos, o ciclo claro-escuro é tido como a principal pista ambiental (Hastings e Boulous, 1991) (Figura 1); no entanto, os agentes sincronizadores só o são assim considerados se representarem para o organismo uma pista importante dentro do contexto em que ele vive. Ou seja, os zeitgebers são organizados hierarquicamente e, algumas vezes, outros são mais importantes do que o ciclo claro-escuro, como por exemplo, alimentação-jejum, variação salina ou de pH, umidade, relações inter e intraespecíficas (comportamentos sociais) (Marques et al., 2003). 


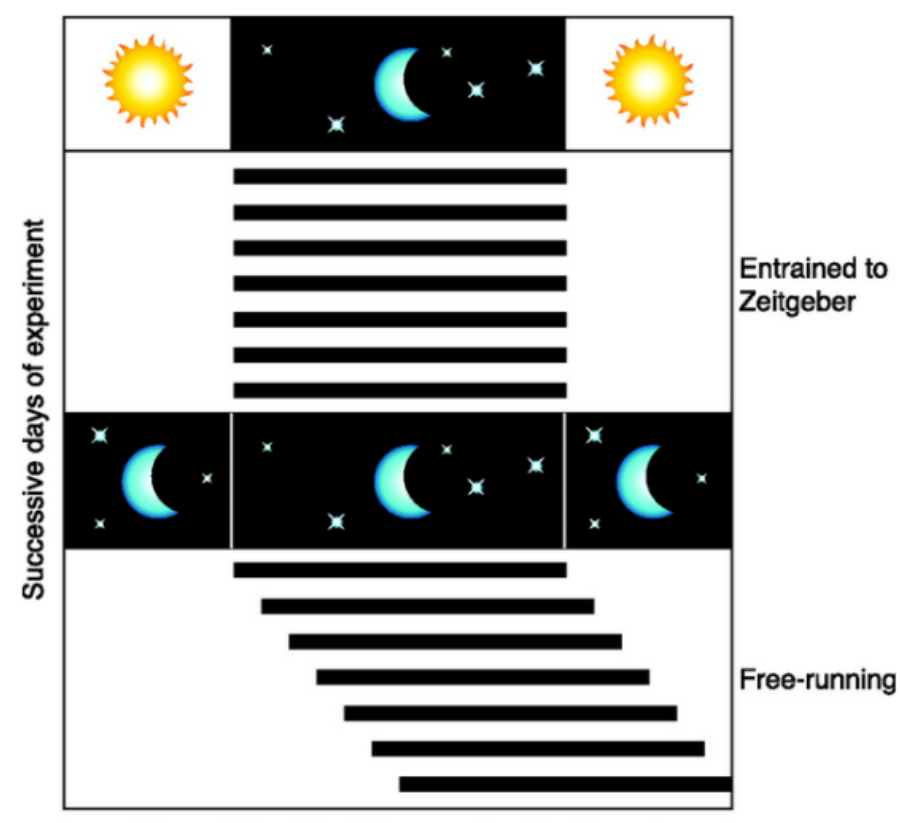

Time of day (clock time or circadian hours)

Figura 1. Modelo Hipotético de Arrastamento pelo Ciclo Claro-Escuro (Golombek e Rosenstein, 2010).

A ubiquidade da manifestação de ritmos nos diferentes tipos de organização constitui-se como uma característica fundamental à matéria viva, demonstrando a importância da organização temporal nos seres vivos e implicando, portanto, em considerar o tempo como uma dimensão fundamental para as formas de vida (Marques et al., 2003).

\section{Relógios Centrais}

Após a comprovação científica da existência de ritmos biológicos endógenos, as pesquisas neste campo avançaram na direção de identificar a região ou órgão que fosse responsável pela geração desta ritmicidade.

Experimentos iniciais em pardais demonstraram que a extirpação da glândula pineal causava arritmicidade (Binkley et al., 1971) e também que o transplante deste órgão, entre indivíduos mantidos em condições de claro-escuro deslocados de 12 horas, 
fazia com que cada individuo passasse a expressar atividade de acordo com a fase determinada pelo doador (Gaston e Menaker, 1968). Com esse conjunto de dados e com os critérios estipulados posteriormente por Inouye e Kawamura em 1979, que uma estrutura considerada oscilador central deveria obedecer, foi possível determinar a glândula pineal como oscilador endógeno nessas aves. Tais critérios são:

- Persistência da oscilação em condições de cultura (in vitro), ou seja, na ausência de aferências e eferências;

- Transferência do padrão de oscilação no caso do transplante do órgão, sendo que o indivíduo transplantado passa a exibir o período e a fase da oscilação correspondente ao que era encontrado no indivíduo doador.

Em mamíferos, a maquinaria central do relógio adquiriu especial importância com estudos de Curt P. Richter que, em 1960, identificou, em pacientes hospitalizados, que parâmetros fisiológicos circadianos eram alterados em decorrência de patologias, resultando em períodos diferentes de $24 \mathrm{~h}$. Sugeriu que os diferentes relógios internos pudessem envolver um ou mais órgãos do corpo e que a localização desses relógios poderia ser periférica ou central. Nos anos seguintes, ele conseguiu demonstrar que o centro responsável pela ritmicidade, em mamíferos, encontrava-se no hipotálamo (Richter, 1960; 1967).

Em continuidade a esses estudos, em 1972, Stephan e Zucker provocaram lesões eletrolíticas bilaterais na região do núcleo supraquiasmático (NSQ) de ratos e observaram a eliminação da ritmicidade circadiana no comportamento de ingestão de água e de atividade locomotora. Ainda nesse mesmo ano, Moore e Eichler fizeram uma marcação radioativa dos nervos que saem da retina e seguem por uma rota distinta daquela responsável pela visão, o trato retino-hipotalâmico, cujo ponto final foi por eles identificado como o NSQ. A partir desses experimentos, foi constatado que o NSQ 
comunica-se com o meio externo através do trato retino-hipotalâmico, garantindo-lhe acesso às informações captadas via retina, além de estar intimamente relacionado aos ritmos biológicos.

De acordo com os critérios já citados, o experimento que faltava para concretizar a ideia de que o NSQ era o oscilador central de mamíferos era o transplante dessa estrutura entre animais que apresentassem diferentes fases ou período para um mesmo ritmo. Foi quando, em 1990, Ralph e seus colaboradores mostraram que o transplante do NSQ de um hamster selvagem para um que apresentava um período circadiano curto imprimia em seu receptor um ritmo com o período do doador. Assim confirmou-se o caráter oscilatório endógeno do NSQ de mamíferos.

A ideia de que os organismos possuem um único oscilador ou relógio circadiano anatomicamente definido permeou os primeiros passos da história da identificação dessas estruturas, em espécies pertencentes aos diversos grupos de vertebrados. O NSQ em roedores e a glândula pineal em aves e répteis eram os grandes representantes desses osciladores únicos. Posteriormente, a retina veio a se juntar como uma terceira estrutura produtora de oscilações auto-sustentadas circadianas (Besharse e Iuvone, 1983; Menaker e Tosini, 1996), demonstrando existir uma pluralidade para estruturas que desempenham o papel de marca-passo central em vertebrados não-mamíferos. "Eixo Circadiano dos Vertebrados" (composto pela retina, glândula pineal e por um conjunto de neurônios hipotalâmicos osciladores) passou a definir o conjunto de estruturas responsáveis pelo relógio biológico central desses grupos. Contudo, esta combinação é variável entre espécies, podendo cada espécie incorporar uma, duas ou todas essas estruturas em seu eixo central circadiano (Zimmerman e Menaker, 1979; Golombek e Aguilar-Roblero, 2003; Bartell et al., 2004). 
Analisando as estruturas consideradas como marca-passo central nos diferentes grupos, é interessante mencionar que enquanto nos mamíferos o oscilador central é localizado no interior do sistema nervoso central e não tem nenhuma capacidade de percepção luminosa, em peixes, anfíbios, répteis e até em moluscos e crustáceos, observam-se osciladores que desempenham a função tanto de fotorreceptores como de osciladores circadianos, sugerindo uma interiorização e uma especialização dos osciladores no curso da história evolutiva (Golombek e Aguilar-Roblero, 2003).

\section{Maquinaria molecular do relógio}

Os relógios biológicos responsáveis pelo programa temporal interno estão codificados no DNA (Hall et al., 1987), e foram estudos genéticos em Drosophila que contribuíram para a descoberta desses mecanismos moleculares. Em 1971, Konopka e Benzer induziram mutações genéticas que resultaram na alteração do período rítmico de Drosophila que, normalmente, é próximo de 24 horas. Dessa maneira, identificaram o gene responsável por essa alteração, ou seja, pela determinação do período nesses animais, que foi denominado $\operatorname{Per}$ (period).

Posteriormente, diversos outros estudos foram realizados e culminaram na identificação dos demais componentes moleculares do relógio de mamíferos, como o gene Clock (Circadian Locomotor Output Cycle Kaput, Vitaterna et al., 1994); gene Per1 em mamíferos (Tei et al., 1997); Per2 e Per3 (Takumi et al., 1998a; 1998b); Bmall (ARNTL, Aryl hydrocarbon Receptor Nuclear Translocator-Like protein, Gekakis et al., 1998); Cry1 e Cry2 (Cryptochrome, Van der Horst et al., 1999). Com esses componentes revelados, a relação entre eles para gerar ritmos com períodos de 24 horas começou a ser desvendada. 
O mecanismo molecular do relógio circadiano envolve processos de retroalimentação positiva e negativa (Figura 2). Nos mamíferos, no primeiro feedback estão os elementos CLOCK e BMAL1 que são membros da família de fatores de transcrição que apresentam o domínio bHLH-PAS (basic Helix-Loop-Helix, PeriodARNT-Single-minded) (Gekakis et al., 1998). Estas duas proteínas formam um heterodímero capaz de se ligar a promotores gênicos que contenham uma sequência Ebox, funcionando como fator de transcrição para a expressão dos genes Per1, Per2 e Per3, Cry1 e Cry2 (Yamaguchi et al., 2000). O feedback negativo (setas vermelhas na Figura 2) é realizado por PER e CRY formando oligômeros com uma caseína quinase (CKle), no citoplasma, onde são fosforilados e transportados para o núcleo. Uma vez no núcleo, bloqueiam a sua própria transcrição ao interagirem com o CLOCK/BMAL1 inibindo sua ação (Young et al., 2001). Além do controle da transcrição de Per e Cry, CLOCK/BMAL1 inicia outra alça de feedback (setas azuis na Figura 2), ativando a transcrição de Rev-erb $\alpha$ e Ror $\alpha$, cujas proteínas competem entre si pela ligação ao elemento responsivo ao ROR (ROREs) presente no promotor de Bmall, onde terão ações antagônicas: ROR ativa a transcrição de Bmall enquanto que REV-ERB a inibe (Ko e Takahashi, 2006). As proteínas REV-ERB $\alpha$ aumentam com a indução da transcrição de Clock/Bmall e vão para o núcleo, ligando-se ao promotor de Bmal1 reprimindo-o. Quando a proteína REV-ERB está ausente, o gene Bmall é liberado, podendo formar novamente o fator de transcrição CLOCK/BMAL1, reiniciando um novo ciclo circadiano (Reppert e Weaver, 2001; Albrecht e Eichele, 2003). O acúmulo de proteínas PER e CRY se mantém em antifase com a transcrição de Rev-Erba. Assim como os genes Rev-erb $\alpha / \beta$ e Ror $\alpha / \beta$, a enzima CK1 $1 \varepsilon$ é um elemento essencial na regulação dos genes de relógio. Ela é responsável pela fosforilação e consequente estabilidade das proteínas PER no citoplasma e sua migração ao núcleo da célula; 
quando PER e CRY são insuficientes para inibir o heterodímero CLOCK/BMAL1, a CKlع atua marcando estas proteínas para posterior degradação (Gachon et al., 2004). Todos esses ciclos em conjunto levam cerca de 24 horas para se completarem e a variação das concentrações dessas diferentes proteínas ao longo do dia constitui a base molecular do relógio biológico.

Basicamente, a organização circadiana é fornecida em nível celular por um relógio molecular, que está presente no sistema nervoso central e também em tecidos periféricos (Zhang et al., 2014). Sendo assim, de que forma essa informação gerada no relógio molecular é transmitida para o organismo? Outros genes, que não os do relógio, também apresentam o elemento E-box em sua região promotora, de modo que sua transcrição também está sob o comando da maquinaria do relógio: CLOCK/BMAL1 (setas verdes na Figura 2). Esses genes, denominados genes controlados pelo relógio (CCGs), codificam as mais diversas substâncias, sejam neuropeptídios, neurotransmissores, hormônios, fatores de transcrição, moléculas de sinalização intracelular, dentre outras. Considerando essa maquinaria do NSQ, as proteínas codificadas pelos CCGs regulam a atividade dos neurônios que, por sua vez, sincronizam o restante do organismo através de inervações diretas sobre o tecido-alvo (Bosek et al., 2009). Assim, os CCGs constituem um dos mecanismos de eferência do relógio circadiano, através do qual o organismo também se conecta a maquinaria central (Zanquetta et al., 2010). 


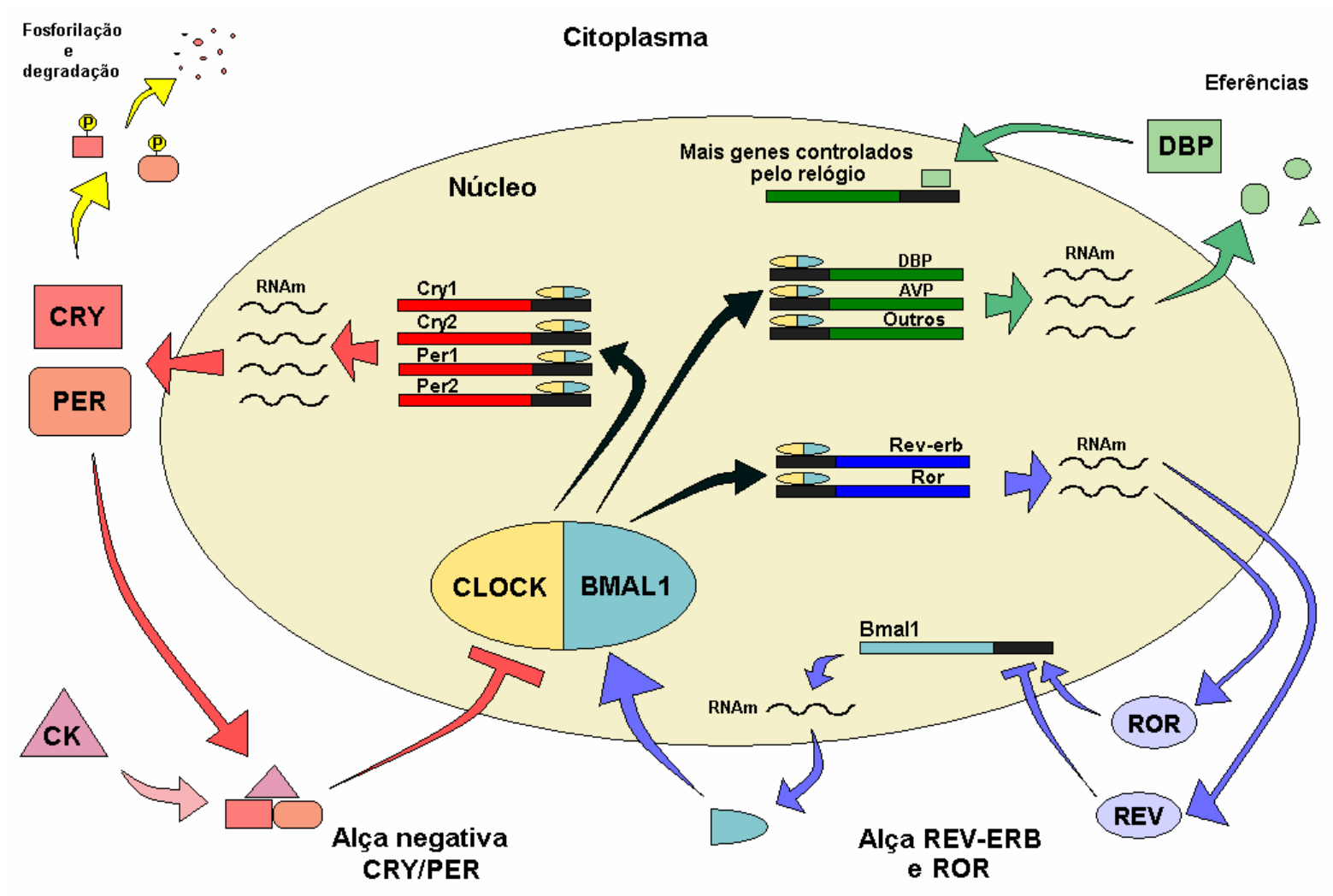

Figura 2. Funcionamento da Maquinaria Molecular do Relógio. Em vermelho, a alça de retroalimentação CRY/PER; setas azuis delimitam a alça REV-ERB e ROR; setas verdes representam as vias de eferência molecular; e as setas amarelas mostram um possível ponto de atraso do sistema, pela fosforilação e degradação dos elementos negativos CRY e PER. DBP (D-box binding protein) e AVP (arginina-vasopressina), genes controlados pelo relógio (Cecon e Flôres, 2010).

\section{Fotorrecepção Circadiana}

Como mencionado anteriormente, o surgimento e a evolução da vida na terra foram possíveis graças ao desenvolvimento de mecanismos temporais precisos capazes de ajustar os processos fisiológicos que ocorriam no interior do organismo com os ciclos ambientais, promovendo assim, ganhos na capacidade adaptativa e reprodutiva desses indivíduos (Klein et al., 1991). Nesse contexto, vale enfatizar novamente, que os ciclos claro-escuro atuam como o principal agente sincronizador dos relógios biológicos de diversas espécies (Hastings e Boulous, 1991). 
A consideração da luz como importante forma de ordenação tempo-espacial é reforçada pela teoria da "Fuga da Luz" que defende que a capacidade de perceber a luz estava indiretamente ligada à capacidade de perceber altas temperaturas que, por sua vez, atuam nocivamente na estabilidade de algumas enzimas e processos fisiológicos. Dessa forma, como as altas temperaturas coincidiam com as fases mais claras do dia, "fugir" da luz seria uma forma eficiente de preservação da homeostase (Pittendrigh, 1993).

Uma ampla gama de fotorreceptores e fotopigmentos evoluíram no sentido de perceber com alta sensibilidade a informação fótica fornecida pelo ambiente (Pittendrigh, 1993). Os fotopigmentos visuais pertencem à família das opsinas, que são proteínas com sete domínios transmembrânicos associadas à proteína $\mathrm{G}$ e com massa aproximada de $30-50 \mathrm{kDa}$. São compostas por uma porção proteica e por uma porção não proteica, um cromóforo, que é um aldeído derivado da vitamina A denominado retinal, responsável pela detecção do sinal luminoso (Spudich et al., 2000; Terakita, 2005). Atualmente, as opsinas podem ser distribuídas em oito famílias diferentes, sendo seis de acordo com a proteína $G$ específica a qual estão acopladas: proteína $G_{t}-$ opsinas visuais de vertebrados; proteína $\mathrm{G}_{\mathrm{i}} / \mathrm{G}_{0}$ - encefalopsina/opsina teleost multiple tissue (tmt, OPN3); proteína $\mathrm{G}_{\mathrm{q}}-$ melanopsinas (OPN4); proteína $\mathrm{G}_{0}$ - opsinas de invertebrados; proteína $\mathrm{G}_{\mathrm{i}}$ - neuropsinas/OPN5; proteína $\mathrm{G}_{\mathrm{s}}$ - opsinas de cnidários. $\mathrm{E}$ outras duas consideradas fotoisomerases: retinocromo e peropsina (Koyanagi e Terakita, 2014).

As opsinas visuais têm sido caracterizadas mais detalhadamente, e é dessa família de opsinas que a rodopsina, responsável pela percepção de luz e formação de imagem nos vertebrados, faz parte. Quando o fóton de luz incide sobre a rodopsina, a energia absorvida é capaz de provocar a isomerização do cromóforo 11-cis-retinal para 
all-trans-retinal, provocando uma série de mudanças conformacionais na molécula da opsina, ativando a proteína $G$ acoplada e consequentemente levando ao desencadeamento da via de sinalização que levará a formação da imagem. A ligação do retinaldeído com a proteína $\mathrm{G}$ ocorre através da base de Schiff, que é relativamente instável, sendo necessária a presença de um contra-íon para promover a estabilidade da ligação. Nos vertebrados, este contra-íon é o glutamato (Terakita, 2005).

Antigamente os fotorreceptores eram classificados como fotorreceptores de vertebrados (ciliares) e fotorreceptores de invertebrados (rabdoméricos). Essa classificação era baseada nas diferentes vias de sinalização, morfologia e especialização das células fotorreceptoras encontradas exclusivamente em vertebrados ou em invertebrados. Esse conceito foi alterado, pois fotorreceptores rabdoméricos foram encontrados em vertebrados, assim como fotorreceptores ciliares foram encontrados em invertebrados (Provencio et al., 2000; Isoldi et al., 2005; Koyanagi e Terakita, 2014). As vias de sinalização desses dois grupos de fotorreceptores são distintas, sendo que nos ciliares, ela se inicia com uma fosfodiesterase e produz potenciais de membrana hiperpolarizantes, e nos rabdoméricos, os potenciais são despolarizantes e utilizam uma cascata que se inicia com a fosfolipase C. Outra diferença entre eles é o fato do cromóforo das opsinas rabdoméricas nunca se separar da proteína, sendo considerado biestável, enquanto nas opsinas ciliares o cromóforo se desacopla da porção proteica e, portanto, é dito monoestável (Arendt et al., 2003).

Embora a percepção visual seja o resultado mais intrigante da capacidade que o nosso sistema nervoso apresenta de captar e processar a informação luminosa, outras funções também são ativadas pela luz. Uma dessas funções é a ação da luz na sincronização dos ritmos biológicos (Menna-Barreto e Díez-Nogueira, 2012). Dentre outras células retinianas, denominadas células ganglionares, foi identificada uma 
subpopulação, aproximadamente $2,7 \%$ do total dessas células, capaz de detectar a presença de luz e ativar uma via nervosa diferente daquela responsável pela formação de imagem. Essas células foram denominadas células ganglionares intrinsicamente fotossensíveis (ipRGCs) (Figura 3) e o fotopigmento que elas expressam é a melanopsina (Provencio et al., 2002).



Figura 3. Células Ganglionares Intrinsicamente Fotossensíveis. Retângulo azul demonstrando a localização das células ganglionares, onde a célula em vermelho (G) representa a subpopulação intrinsicamente fotossensível. SCN: Núcleo Supraquiasmático; C: Cones; R: Bastonetes; H: Células horizontais; B: Células bipolares; A: Células amácrinas; G: Células ganglionares (Modificado de Reppert e Weaver, 2002).

A melanopsina foi descoberta em melanóforos de Xenopus laevis (Figura 4) (Provencio et al., 1998) e, posteriormente, identificada na retina de Xenopus e de todos os grupos de vertebrados estudados até o momento, incluindo o homem (Provencio et 
al., 2000; Bellingham et al., 2006; Davies et al., 2010). Como mencionado, em mamíferos, a melanopsina encontra-se nas ipRGCs; nos répteis, esse fotopigmento encontra-se em regiões cerebrais mais discretas e no olho parietal, além dos olhos laterais (Frigato et al., 2006); em aves, nas células ganglionares e horizontais (Lima et al., 2006) e em todos os tipos celulares retinianos do teleósteo Danio rerio (Davies et al., 2011).
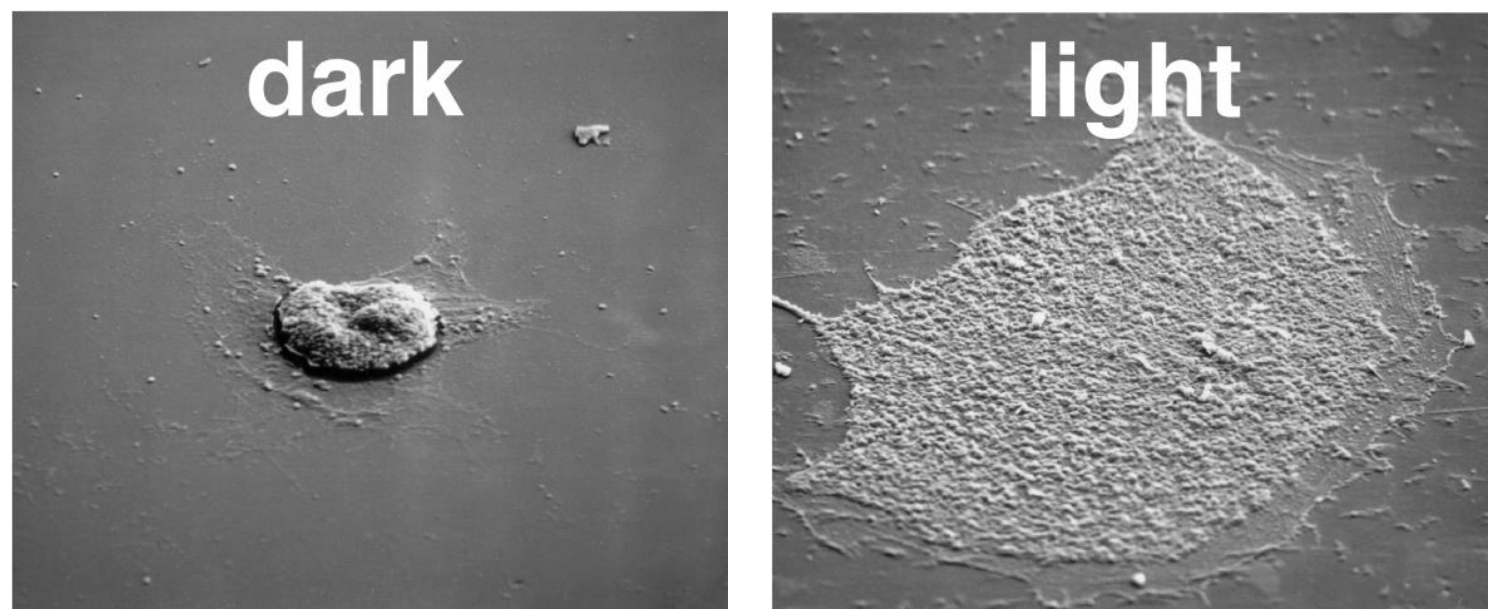

Figura 4. Melanóforos de Xenopus laevis. Em dark, grânulos de melanina agregados ao redor do núcleo (células mantidas em escuro constante). Em light, dispersão dos grânulos de melanina pelo citoplasma após o estimulo luminoso. Imagem gentilmente cedida por Mark D. Rollag.

Durante várias décadas, os pesquisadores estavam intrigados pelo fato de camundongos $r d / r d$, nos quais não há bastonetes e apenas uma mínima porcentagem de cones permanece funcional (Carter-Dawson et al., 1978), serem ainda capazes de ajustar seu relógio central ao ciclo claro-escuro. Somente em 2003, Panda e colaboradores demonstraram que a completa perda das respostas não-visuais a estímulos luminosos, como supressão da síntese de melatonina, constricção pupilar e arrastamento do NSQ, somente ocorria em camundongos $r d / r d$ se o gene para melanopsina fosse nocauteado. Esses estudos revelaram a melanopsina como o principal componente para a sincronização do relógio circadiano (Panda et al., 2003). 
Com base em estudos filogenéticos, que apontavam baixa similaridade entre a melanopsina de mamíferos e a de outros vertebrados não-mamíferos (Bellingham e Foster, 2002), hipotetizava-se a existência de diferentes genes que codificariam essa opsina. Em 2006, Bellingham e colaboradores demonstraram a existência de dois genes Opn4 codificando melanopsinas em vertebrados não-mamíferos. O novo gene foi identificado como $\mathrm{Opn} 4 \mathrm{~m}$, pois ele representa o verdadeiro ortólogo de mamíferos, e o gene antigo, expresso apenas em vertebrados não-mamíferos, ficou sendo $O p n 4 x$.

Estudos em Danio rerio demonstraram a existência de cinco genes na retina do animal adulto, que codificam melanopsinas nessa espécie, $O p n 4 m 1, O p n 4 m 2, O p n 4 m 3$, Opn4x1 e Opn4x2 (Davies et al., 2011), o que também foi identificado em nosso laboratório, em células embrionárias ZEM-2S desta mesma espécie (Ramos et al., 2014). Contudo, ainda se faz necessária a realização de mais estudos que elucidem a redundância da expressão de duas ou mais melanopsinas em vertebrados nãomamíferos.

\section{Relógios Periféricos}

Nos mamíferos, quase todos os aspectos da fisiologia e comportamento estão sob o controle do sistema circadiano e durante muito tempo acreditou-se que o NSQ era o único regulador desses ritmos neste grupo. Contudo, estudos pioneiros indicaram que a restrição da disponibilidade de alimentos, por exemplo, poderia sincronizar diversos ritmos circadianos de ratos com lesão no NSQ (Krieger, 1974; Krieger et al., 1977). Dessa maneira, essas observações levaram a acreditar que, além do NSQ, outras regiões poderiam também estar envolvidas na expressão da ritmicidade endógena.

Mais tarde, no final dos anos 90, alguns estudos identificaram a transcrição de genes do relógio em tecidos periféricos (Balsalobre et al., 1998; Zylka et al., 1998), 
demonstrando, pela primeira vez, a expressão desse grupo de genes fora do NSQ. Balsalobre e colaboradores (1998) observaram que fibroblastos de ratos submetidos a choque de soro fetal bovino apresentavam alterações nos ritmos da expressão de genes do relógio. Outro estudo identificou que órgãos de ratos transgênicos Per1::Luc apresentavam ritmicidade na expressão do gene Perl (Yamazaki et al., 2000); e, um ano depois, Yagita e colaboradores (2001) demonstraram, também através de bioluminescência, que fibroblastos em cultura exibiam oscilações autossustentadas e osciladores autônomos, semelhantemente ao NSQ. Desses estudos, reforçou-se a conclusão de que outros tecidos eram capazes de gerar ritmos de forma independente do relógio central.

A atividade destes osciladores periféricos também depende de alças de autorregulação de genes e proteínas do relógio, assim como para o marca-passo central; porém possuem zeitgebers distintos daqueles do NSQ, uma vez que respondem a diferentes estímulos ambientais e fisiológicos. Como mencionado anteriormente, o principal sincronizador do NSQ é a informação do ciclo claro-escuro, enquanto que os relógios periféricos podem ter seus ritmos arrastados, por exemplo, pelo estímulo alimentar, sem que o período do relógio central seja alterado (Damiola et al., 2000; Stokkan et al., 2001).

$\mathrm{Na}$ tentativa de entender como os relógios periféricos se comunicavam com o relógio central, estabeleceu-se uma ideia inicial de hierarquia, de modo que o sinal proveniente do NSQ seria indispensável para a manutenção dos ritmos periféricos. Resultados demonstrados por Yamazaki e colaboradores (2000) corroboravam essa ideia, apontando que fatias do NSQ apresentavam ritmo constante de expressão de Perl, enquanto que explantes de pulmão e fígado rapidamente perdiam suas oscilações. Todavia, outros muitos estudos sobre a ritmicidade periférica caracterizaram, em 
diversos tecidos, a independência em relação ao oscilador central (Abe et al., 2002; Bartell et al., 2004; Yoo et al., 2004; Costa et al., 2005), conjecturando uma nova proposta para a temporização circadiana. Nesta proposta, os relógios periféricos ajustariam temporalmente as atividades do órgão, ampliando a mensagem funcional enviada pelo relógio central, trazendo para o sistema circadiano um conceito muito mais integrativo e complementar do que hierárquico (Araújo e Marques, 2003). Em resumo, in vivo, o oscilador central atua promovendo o acoplamento dos relógios periféricos, como forma de garantir a homeostase do organismo e, na ausência do NSQ, os relógios periféricos passam a expressar seu ritmo endógeno (Figura 5) (Gachon et al., 2004).

A

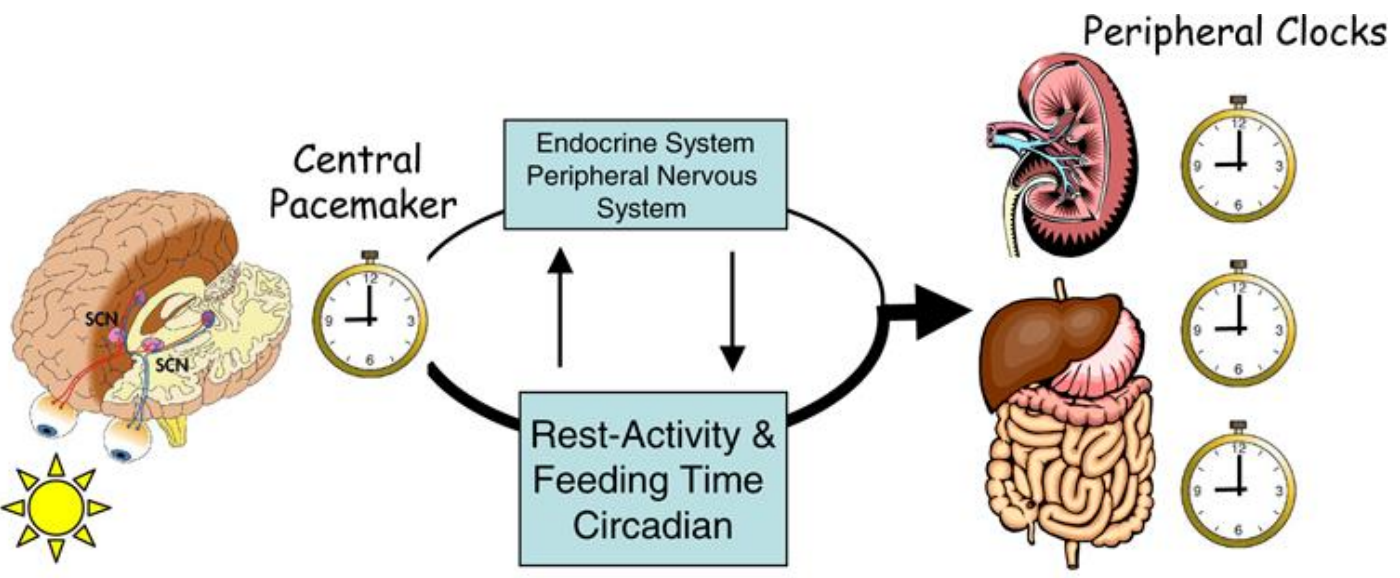

B
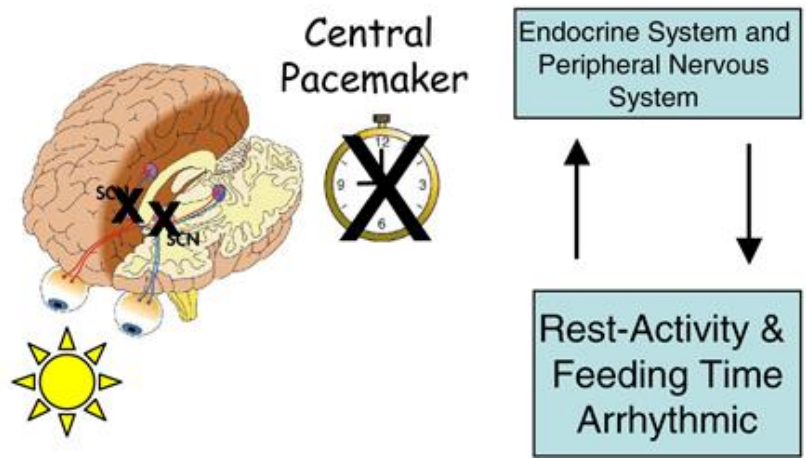

Peripheral Clocks

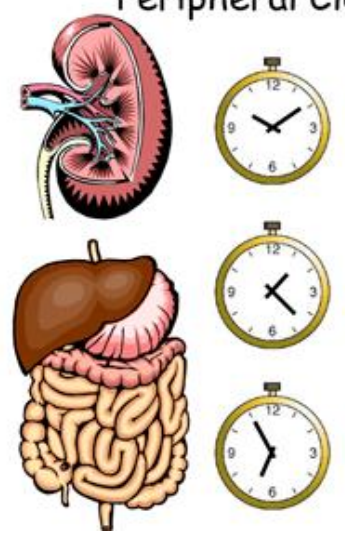

Figura 5. Sincronização do Sistema Circadiano de Mamíferos. (A) Relógio central sincronizado pela informação de ciclo claro-escuro, atuando no acoplamento dos relógios periféricos. (B) Após lesão do NSQ, os relógios periféricos continuam oscilando, mas manifestando cada um o seu período de ritmo endógeno. (Gachon et al., 2004). 
Paralelamente a esses estudos em mamíferos, também foram identificados diversos osciladores independentes em vertebrados não-mamíferos. O teleósteo Danio rerio, popularmente conhecido como zebrafish, possui rins e coração diretamente fotossensíveis quando isolados em cultura, sendo sincronizados pelos ciclos claroescuro (Whitmore et al., 1998; Whitmore et al., 2000). Em adição, foi demonstrado nesse peixe a existência de seis genes Crys (cryla, 1b, 2a, 2b, 3 e 4) e quatro genes Pers (perla, 1b, 2 e 3), todos exibindo um padrão cíclico de expressão quando em ciclo claro-escuro (Cahill, 2002). Demonstramos em nosso laboratório que células da linhagem embrionária ZEM-2S de Danio rerio são sincronizadas pelo ciclo claro-escuro apresentando um perfil circadiano da expressão dos genes Perl e Crylb (Farhat et al., 2009). Recentemente demonstramos que um pulso de luz azul, comprimento de onda que maximamente ativa a melanopsina, é indutor da expressão dos genes Per2 e Cryla, indicando esta opsina como fotopigmento funcional nessa linhagem (Ramos et al., 2014).

Assim como em células embrionárias ZEM-2S, a maquinaria molecular do relógio presente nos melanóforos do anfíbio Xenopus laevis também é sincronizada por ciclos claro-escuro e apresenta transcrição aumentada dos genes Perl e Per2 em resposta ao pulso de luz azul (Moraes et al., 2014a).

Se compararmos os relógios periféricos de mamíferos aos de vertebrados nãomamíferos, temos que nos primeiros, esses osciladores dependem principalmente de sinais sincronizadores neurais diretos ou humorais indiretos do oscilador central para manter a homeostase do organismo (Yamazaki et al., 2000; Bertell et al., 2004). Contrariamente, em vertebrados não-mamíferos, especificamente em alguns teleósteos e 
anfíbios, os tecidos periféricos podem ser fotossensíveis, e sincronizáveis pela luz até mesmo quando isolados (Whitmore et al., 2000).

Em mamíferos, a melatonina produzida pela pineal é considerada o mensageiro do escuro, um dos mais importantes outputs do relógio central, refletindo a duração exata da fase escura do dia. Efeitos da melatonina sobre a sincronização dos tecidos periféricos têm sido extensivamente estudados na maioria dos sistemas fisiológicos, tais como o ciclo do sono-vigília, a reprodução, o sistema cardiovascular e a pressão sanguínea, o metabolismo energético (Pevet et al., 2011; Hazlerigg, 2012). No entanto, em vertebrados não-mamíferos, as ações da melatonina sobre relógios periféricos foram menos investigadas. Em fibroblastos de mamíferos, o registro de bioluminescência mostrou que a melatonina aumenta a amplitude da expressão de Perl sem alterar os parâmetros oscilatórios observados nas células controle (Sandu et al., 2015). Em melanóforos de X. Laevis a melatonina também não alterou o perfil oscilatário de expressão de Perl, embora reduziu drasticamente a amplitude do ritmo (Moraes et al., 2014b; Poletini et al., 2015a).

Por fim, de uma forma simplista, temos uma notável centralização dos elementos fotorreceptivos em mamíferos, onde a informação luminosa é trazida exclusivamente pela retina, e o papel de fatores humorais sinalizando entre relógio central e periférico é extremamente relevante. Já em vertebrados não-mamíferos observam-se outras vias de entrada do sinal luminoso; contudo em ambos os grupos, essa informação culmina na coordenação dos relógios periféricos via relógio central (Figura 6). 


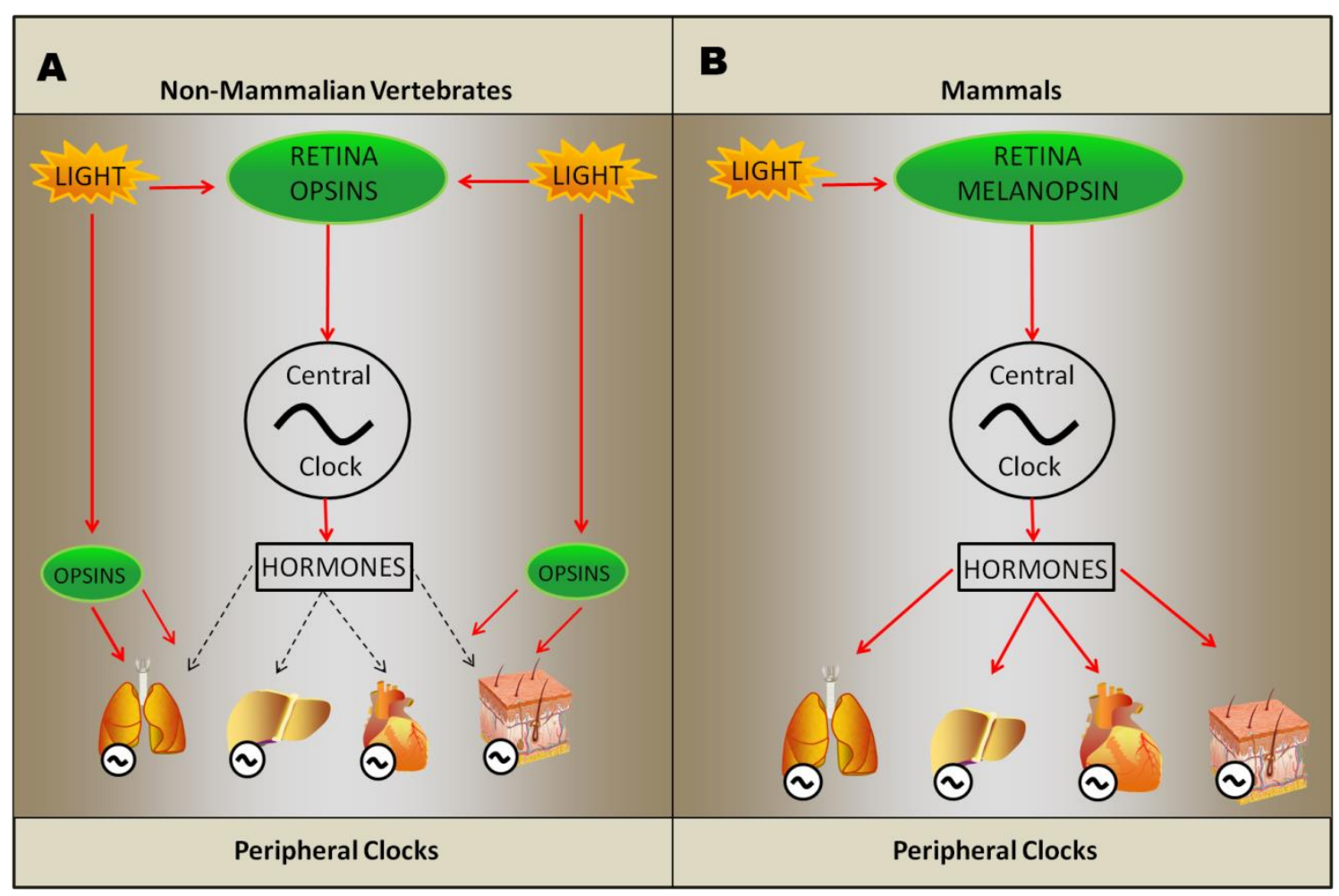

Figura 6. Sincronização dos Relógios Periféricos em Vertebrados Não-mamíferos e

Mamíferos. (A) Regulação dos ritmos endógenos em vertebrados não-mamíferos, onde a captação do sinal luminoso ocorre pela retina e também por outros tecidos periféricos. (B) Percepção de luz exclusivamente via retina em mamíferos, coordenando a ritmicidade periférica via NSQ (Poletini et al., 2015a).

\section{Temperatura}

A vida está diretamente conectada à temperatura e, para manter a homeostase, os organismos vivos estão constantemente respondendo às mudanças nas temperaturas ambiente e corporal através de uma variedade de respostas fisiológicas e comportamentais, já que com pequenas alterações da temperatura central, podem ocorrer alterações metabólicas e enzimáticas extremamente prejudiciais ao organismo (Bouchama e Knochel, 2002; Brown et al., 2012). 
A termorregulação é realizada por um sistema cujos componentes iniciais são termorreceptores centrais e periféricos. Nesse sistema, encontram-se duas redes distintas de neurônios, a de condução aferente, responsável pelo transporte da informação térmica para o centro de integração, e a de respostas eferentes, levando a respostas compensatórias. É o NSQ que regula a temperatura do corpo ao integrar os impulsos térmicos provenientes de quase todos os tecidos do organismo, o que tem sido considerado como temperatura corporal média. Quando o impulso integrado excede ou fica abaixo da faixa limiar de temperatura, ocorrem respostas termorreguladoras autonômicas, que mantêm a temperatura do corpo em valor adequado, não precisando de um controle central (Romanovsky, 2007).

No hipotálamo anterior é feita a integração das informações aferentes térmicas, enquanto no hipotálamo posterior iniciam-se as respostas efetoras. $\mathrm{Na}$ área pré-óptica do hipotálamo existem neurônios sensíveis à temperatura, que podem ser classificados em neurônios sensíveis ao calor e neurônios sensíveis ao frio, estes últimos predominantes. É importante mencionar a presença de neurônios sensíveis à estimulação térmica local no hipotálamo posterior, na formação reticular e também na região medular (Dikenson, 1977).

Frente às variações de temperatura, as reações bioquímicas no organismo reagem acelerando ou diminuindo sua velocidade. No entanto, no que diz respeito aos ritmos biológicos e suas respostas a grandes variações de temperaturas, apenas modificações sutis no período endógeno são geralmente detectadas (Marques et al., 2003). Contudo, experimentos in vitro mostraram que ciclos de temperatura externa podem afetar a expressão rítmica de genes de relógio em fibroblastos de ratos (células Rat-1) e em culturas primárias de células gliais, e o mesmo também foi identificado em estudos in vivo em relógios periféricos (Brown et al., 2002; Prolo et al., 2005), 
contrariando o que é observado no relógio central. Entretanto, essa baixa suscetibilidade central à temperatura parece ser uma propriedade interessante no que se refere a processos bioquímicos de geração dos padrões rítmicos, já que assim são minimizados riscos ao funcionamento adequado do relógio (Marques et al., 2003).

Tendo em vista essas informações, questiona-se a base do mecanismo de controle da temperatura no oscilador endógeno dos seres vivos, uma vez que o mecanismo molecular de relógios centrais e periféricos é tão semelhante. A temperatura, assim como a luz, também é capaz de sincronizar ritmos de atividade em muitos organismos, tanto nos vertebrados ectotérmicos (por ex. peixes, Lahiri et al., 2005) como em invertebrados e organismos mais primitivos (cianobactérias, Yoshida et al., 2009; Neurospora, Liu et al., 1998; Caenorhabditis elegans, Van der Linden et al., 2010; Drosophila, Glaser et al., 2005).

Nos vertebrados ectotérmicos, variações de $1 \mathrm{a} 2^{\circ} \mathrm{C}$ podem arrastar os ritmos, e a extensão dos deslocamentos de fase depende da amplitude e da duração dessa variação. Estas respostas são muito semelhantes àquelas disparadas por pulsos de luz (Rensing e Ruoff, 2002). Em trabalho recente, Villamizar e colaboradores (2012) evidenciaram, no teleósteo Danio rerio, que ciclo de temperatura $28: 24^{\circ} \mathrm{C}$ coincidindo com ciclo claroescuro ou temperatura constante de $28^{\circ} \mathrm{C}$ tinham o efeito de acelerar o nascimento e crescimento dos alevinos e estimular a atividade de enzimas ovarianas e testiculares, quando comparado a ciclo claro-escuro apenas.

Embora mamíferos não se ajustem a ciclos de temperatura ambiente, a temperatura corporal pode variar 2 a $4^{\circ} \mathrm{C}$. Tal oscilação é suficiente para sincronizar a maquinaria do relógio em uma série de tecidos periféricos (Buhr et al., 2010). Dessa forma, é possível afirmar que o NSQ coordena o ritmo de temperatura corporal, resistindo aos ciclos de temperatura e, ao mesmo tempo, levando informações temporais 
para os relógios periféricos através da linguagem universal da temperatura (Edery, 2010). Recentemente foi demonstrado que a área pré-óptica é responsável pelo controle circadiano da temperatura corpórea (Vriens et al., 2014) e sabe-se que ela também recebe o sinal circadiano do NSQ (Buijis et al., 2003).

Diversos trabalhos vêm mostrando o envolvimento de canais iônicos do tipo TRP (Transient Receptor Potential) na detecção de temperatura em mamíferos. A história dos canais TRP iniciou-se em 1969 com a descoberta de uma disfunção na cascata de fototransdução em Drosophila, com potenciais de ação atípicos. Após o estímulo por luz, apenas uma despolarização transitória era observada e, de 5 a 10 segundos após o estímulo, apenas os valores basais eram registrados ao invés do plateau característico (Cosens e Manning, 1969). Posteriormente, outros pesquisadores demonstraram que esse fenótipo não foi causado por um problema na regeneração do fotopigmento ou por ativação de canais fotossensíveis, como se acreditava. Mas que ele estava ligado a outro tipo de canal e, como o resultado deste defeito foi um potencial transiente do receptor, estes mutantes foram denominados TRP (Minke et al., 1975, 1982). Por fim, em 1989, foi desvendado o culpado desta disfunção, dando início à identificação e caracterização de mais de 50 canais TRP encontrados numa ampla variedade de organismos (Montell et al., 1989). Contudo, a confirmação de que os TRP eram, de fato, canais catiônicos, só veio quando foi usado um bloqueador inespecífico para canais de $\mathrm{Ca}^{2+}$, lantanio, em retina de moscas Calliphora, demonstrando uma diminuição considerável do potencial de ação nos fotorreceptores após um pulso de luz, chegando ao nível observado no escuro (Hochstrate, 1989).

Atualmente se conhecem sete subfamílias de canais TRP, agrupadas em mamíferos como: TRPC (clássica ou canônica), TRPV (vaniloide), TRPM (melastatina) TRPA (ankyrin), TRPP (policisteína) TRPML (mucolipina) e TRPN (no 
mechanoreceptor potential C, NOMPC) (Flockerzi, 2014). Análises funcionais destes canais revelaram seu envolvimento em vários tipos de percepções sensoriais: sensação térmica, mecanocepção, quimiocepção, nocicepção, bem como percepção de luz (Voets et al., 2005).

Nos mamíferos, a ativação dos canais TRP é seguida por um influxo de cálcio que pode gerar potenciais de ação em neurônios sensoriais, caracterizando o início do processo de transdução de sensação térmica (Dhaka et al., 2006). Dentre os TRP envolvidos na termocepção, destacam-se: TRPV1, TRPV2, TRPV3, TRPV4, TRPM2, TRPM4 e TRPM5 para calor e TRPA1 E TRPM8 para frio (Dhaka et al., 2006). Destes canais TRP, comprovou-se que o TRPM8 (Bautista et al., 2007; Colburn et al., 2007; Dhaka et al., 2007), o TRPV3 (Moqrich et al., 2005) e o TRPV4 (Lee e Caterina, 2005), de fato, participam da percepção de temperatura em mamíferos. Em conjunto, toda a família TRP responde à maior parte das temperaturas às quais os mamíferos são expostos, mesmo as que possam ser nocivas a eles (Caterina et al., 1997). Esta variedade de espectros de temperatura para ativação desses canais parece funcionar de forma semelhante aos fotopigmentos presentes nos fotorreceptores, já que nos fotopigmentos a ativação é baseada em um comprimento de onda específico e nos TRP a ativação se baseia em variações específicas de temperatura, corroborando com a ideia de co-evolução desses sistemas.

A demonstração de que a detecção de temperatura mediada por canais TRP em Drosophila é dependente da rodopsina e que a termossensibilidade na ausência de rodopsina é restaurada pela transfecção com o fotopigmento melanopsina (Shen et al., 2011) estimulou significativamente a investigação das vias intracelulares comuns à transdução dos sinais luminoso e térmico. Adicionalmente, Bellono e colaboradores (2013) relataram que melanócitos humanos expostos a luz ultravioleta A (UVA) 
respondem com uma produção rápida de melanina envolvendo um receptor acoplado a proteína $\mathrm{G}$ dependente de retinal e que, em última instância, ativa canal TRPA1. Esta via de fototransdução é similar à via da melanopsina na retina, indicando mais uma vez a importância da compreensão das vias de sinalização que convergem para canais TRP, e sua relação com a fisiologia de relógios periféricos (Figura 7).
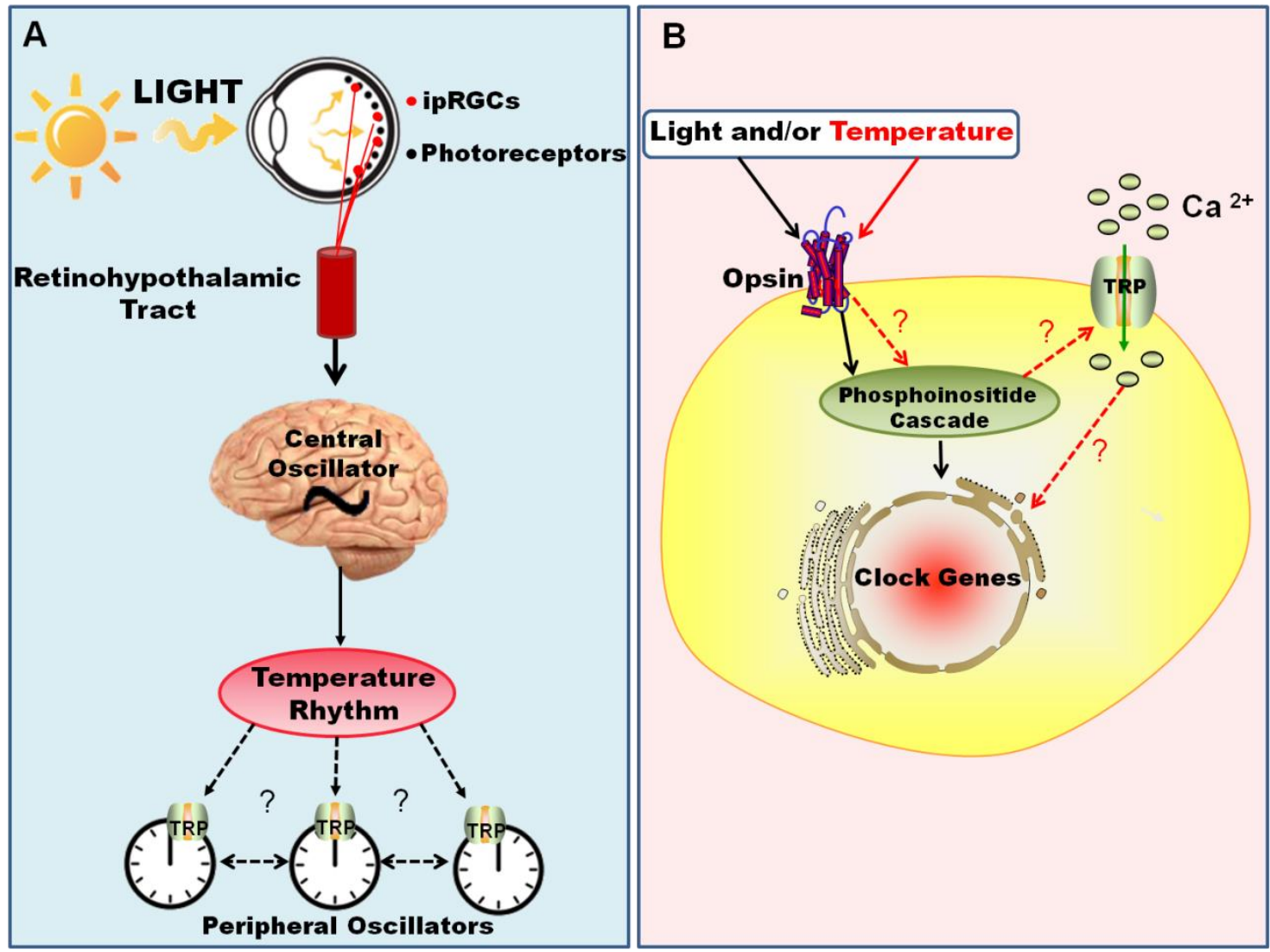

Figura 7. Modelo Hipotético para a Co-evolução dos Sistemas de Fotorrecepção e Termocepção. (A) A percepção de luz em mamíferos é restrita à retina, onde a informação é percebida pelas ipRGCs e viaja através do trato retino-hipotalâmico até o oscilador central, resetando a maquinaria molecular do relógio. A variação circadiana da temperatura, que é controlada pelo NSQ, é transmitida para os vários relógios periféricos, possivelmente através de canais TRP. (B) Invertebrados e vertebrados não-mamíferos podem ser capazes de perceber luz e/ou temperatura através de tecidos periféricos, integrar essa informação, e arrastar o relógio local de uma única célula (Poletini et al., 2015b). 


\section{Objetivos}

"A menos que modifiquemos a nossa maneira de pensar, não seremos capazes de resolver os problemas causados pela forma como nos acostumamos a ver o mundo".

Albert Einstein 
1. Determinar o papel da luz e temperatura como agentes sincronizadores em melanócitos B16-F10 Per1::Luc clone 9, submetendo essas células a pulsos de 650 lux $\left(95,17 \mu\right.$ watts $\left./ \mathrm{cm}^{2}\right)$ de luz de azul (450-475 nm, 3 watts, Golden plus, São Paulo, Brasil) e de temperatura $\left(2,5^{\circ} \mathrm{C}\right.$ acima daquela de manutenção, $\left.37^{\circ} \mathrm{C}\right)$ verificando a expressão gênica de Perl pela bioluminescência observada;

2. Investigar o papel do canal TRPV1 na transdução do sinal luminoso exercido em camundongos íntegros, pela análise da expressão gênica de Per1, Per2, Clock e Bmall em glândula suprarrenal, fígado e tecido adiposo marrom de animais selvagens (WT) e nocautes (KO) para TRPV1, submetidos a diferentes condições de iluminação. 


\section{Material e Métodos}

"A tarefa não é tanto ver aquilo que ninguém viu, mas pensar o que ninguém ainda pensou sobre aquilo que todo mundo vê." Arthur Schopenhauer 


\section{Melanoma B16-F10 Per1::Luc de Mus musculus}

\subsection{Cultura de Células}

Células da linhagem de melanoma murino B16-F10 foram mantidas em meio RPMI 1640 suplementado com 14,3 mM de $\mathrm{NaHCO}_{3}, 15 \mathrm{mM}$ de HEPES (Sigma, Brasil), $10 \%$ de soro fetal bovino (SFB, Atena, Brasil) e $1 \%$ de solução de antibiótico/fungicida $(10.000 \mathrm{U} / \mathrm{mL}$ penicilina/10.000 $\mu \mathrm{g} / \mathrm{mL}$ estreptomicina/25 $\mu \mathrm{g} / \mathrm{mL}$ anfotericina B) (Life Technologies, EUA), $\mathrm{pH} 7,2$, em estufa úmida a $37^{\circ} \mathrm{C}$ e $5 \% \mathrm{CO}_{2}$.

$\mathrm{O}$ vetor PGL-3-Luciferase $(L u c)$ carregando o promotor do gene Per1 (plasmídeo cedido pela Profa. Carla Green, University of Texas Southwestern Medical Center, Dallas, EUA), juntamente com o vetor pcDNA 3.1 (Life Technologies, EUA) que carrega a sequência que confere resistência a neomicina, foram linearizados respectivamente com as enzimas de restrição $S a l 1$ e $S c a 1$ (Fermentas, EUA). Células B16-F10 foram transfectadas por eletroporação (AMAXA Nucleofector, Lonza, EUA, tampão V, programa P-020) com ambos os plasmídeos linearizados. Após seleção com o análogo da neomicina, geneticina ( $900 \mathrm{ng} / \mathrm{mL}$, Life Technologies, EUA), as células resistentes foram separadas e cultivadas. Os vários clones foram testados para a expressão de luciferase por reação de PCR (primers: forward- 5'-ATT TAT CGG AGT TGC AGT TGC GCC-3'; reverse- 5'-TCC AGA TCC ACA ACC TTC GCT TCA-3'). Estabeleceu-se assim uma linhagem estável B16-F10 expressando Per1::Luc, mantida nas mesmas condições da linhagem mãe, mas acrescentando-se durante a manutenção 200 ng/mL de geneticina para garantir uma população pura de células transfectadas.

\subsection{Efeito do Pulso de Luz ou de Temperatura}

As células B16-F10-Per $1:$ Luc clone 9 foram semeadas em placas de $35 \mathrm{~mm}$ de diâmetro na densidade de $10^{6}$ em 2 mL de meio RPMI 1640 suplementado com $10 \%$ de 
SFB e $1 \%$ de solução de antibiótico/fungicida $(10.000 \mathrm{U} / \mathrm{mL}$ penicilina/10.000 $\mu \mathrm{g} / \mathrm{mL}$ estreptomicina/25 $\mu \mathrm{g} / \mathrm{mL}$ anfotericina B) (Life Technologies, EUA).

Após adesão overnight, o meio das placas foi substituído por meio com $2 \%$ de SFB, luciferina (Promega, EUA) $10^{-4} \mathrm{M}$ e $1 \%$ de solução de antibiótico/fungicida, as placas foram cobertas com lamínulas impregnadas com silicone para perfeita vedação, levadas para o equipament Lumicycle (Actimetrics, EUA) (dia 0) e mantidas em condições constantes (DD). A expressão de Perl foi monitorada por 4 dias e no início do $5^{\circ}$ dia, as células foram submetidas a um pulso de $1 \mathrm{~h}$ de temperatura $2,5^{\circ} \mathrm{C}$ acima daquela de manutenção $\left(37^{\circ} \mathrm{C}\right)$ ou 10 min de luz de LED azul (450-475 nm, 3 watts, Golden plus, São Paulo, Brasil) com intensidade de 650 lux $\left(95,17 \mu\right.$ watts $\left./ \mathrm{cm}^{2}\right)$, continuando a serem monitoradas no Lumicycle por 3 dias adicionais. O registro nos 3 dias iniciais em DD foi considerado como controle para o registro nos dias após os pulsos. O tempo do controle foi redimensionado para que $\mathrm{t}=0$ correspondesse a $24 \mathrm{~h}$ após o início da leitura, para desconsiderar os valores do pico inicial correspondente ao tratamento com luciferina.

A bioluminescência emitida pelas células foi medida em intervalos de 10 min, durante 77 seg no Lumicycle, luminômetro de microplaca equipado com tubos fotomultiplicadores (Lumicycle®; Actimetrics, EUA). Os registros de bioluminescência foram analisados com o programa Lumicycle Analysis usando um método de subtração da média de 24 h e alisado pela média de $2 \mathrm{~h}$. O período também foi determinado pelo programa Lumicycle Analysis.

\section{Quantificação Gênica em Glândula Suprarrenal, Fígado e Tecido Adiposo}

\section{Marrom de Mus musculus Submetidos in Vivo a Diferentes Protocolos de Luz}

Os experimentos in vivo foram realizados na Universidade da Virginia, Estados Unidos, através de uma colaboração entre a professora Ana Maria Castrucci e os 
professores Michael Menaker e Ali Guler. O professor Ali Guler possui animais nocaute para canais TrpVl, os quais foram usados em nossos protocolos experimentais, aprovados pelo Comitê de Ética em Experimentação Animal daquela instituição.

Os protocolos de experimentos in vivo foram realizados pela professora Ana Maria Castrucci e a extração de RNA e síntese de cDNA pela Profa. Castrucci e pela pós-doutoranda do nosso laboratório, Maria Nathália Moraes, na Universidade de Virginia.

Para todos os protocolos a seguir, camundongos machos selvagens (WT) e nocautes para o canal $\operatorname{Tr} p V 1(\operatorname{Tr} p V 1 \mathrm{KO})$ com idades entre 2 e 4 meses foram mantidos em gaiolas individuais com rodas de atividade. Cada cinco gaiolas foram colocadas dentro de um caixão (coffin) de madeira pintada de preto, onde foi possível controlar a luminosidade e manter a temperatura constante.

a) Escuro Constante. Os animais foram mantidos durante 10 dias em condições constantes (DD). Ao final deste e dos protocolos seguintes, os animais foram sacrificados por $\mathrm{CO}_{2}$ em S2 e S14 (respectivamente 2 e 14 horas após o início da atividade), sendo coletados núcleo supraquiasmático, glândulas suprarrenais, fígado, tecido adiposo marrom interescapular e retinas para posterior extração de RNA total.

b) Arrastamento fótico. Os animais foram mantidos em LD 12:12 (luz acesa às 7 e apagada às 19 horas) por 6 dias, após os quais a luz foi apagada às $13 \mathrm{~h} \mathrm{e}$ acesa à 1 h, por mais 6 dias (avanço de fase). Nos 6 dias seguintes, a luz voltou a ser acesa às 7 e apagada às 19 horas (atraso de fase). Ao final desse período, os animais foram sacrificados por $\mathrm{CO}_{2}$ em S2 e S14 (respectivamente 2 e 14 horas após o início da atividade) e os mesmos órgãos coletados. Na fotofase, a intensidade luminosa dentro dos coffins variou de 1000 a 1200 lux. 
c) Luz constante: alongamento do período. Os animais foram mantidos 3 dias em LD 12:12 seguidos por 14 dias sob regime de luz constante LL. Ao final do protocolo os animais foram sacrificados por $\mathrm{CO}_{2}$ em S2 e S14 (respectivamente 2 e 14 horas após o início da atividade) e os mesmos órgãos coletados. A intensidade luminosa dentro dos coffins variou de 1000 a 1200 lux.

Após a realização destes protocolos, RNA total foi extraído, o cDNA foi sintetizado e trazido para o Brasil, onde foi submetido a reações de PCR quantitativo, realizados por mim, na Universidade de São Paulo.

\subsection{Extração de RNA e RT-PCR}

Os órgãos foram homogeneizados com homogeneizador com pistilos autoclaváveis (Sigma, EUA) em $300 \mu \mathrm{L}$ de Trizol (Life Technologies, EUA) em eppendorfs de 1,5 mL. A seguir, o volume de Trizol foi completado para $1 \mathrm{~mL}$ e o lisado celular coletado em novo eppendorf e incubado por 5 min à temperatura ambiente, para permitir a completa dissociação das proteínas nucleares. Ao lisado celular, foram adicionados $200 \mu \mathrm{L}$ de BCP (1-bromo-3-cloropropano, Fisher Science, EUA) seguido de agitação vigorosa por $15 \mathrm{seg}$ e descanso de $10 \mathrm{~min}$ em temperatura ambiente. Após centrifugação a 12.000 x g por 15 min a $4^{\circ} \mathrm{C}$, separou-se a fase superior que contém RNA $(500 \mu \mathrm{L})$, que foi precipitado com a adição de $650 \mu \mathrm{L}$ de isopropanol (Sigma, EUA), por 10 min em temperatura ambiente, seguido de centrifugação a 12.000 $\mathrm{x} g$ por $35 \mathrm{~min}$ a $4^{\circ} \mathrm{C}$. O sobrenadante foi removido, o RNA lavado com 1,3 mL de etanol $75 \%$ (2x), evaporado em temperatura ambiente e ressuspendido em $20 \mu \mathrm{L}$ de água tratada com dietil-pirocarbonato $\left(\mathrm{H}_{2} \mathrm{O}\right.$ DEPC, Ambion Inc., EUA). Para remoção de eventual contaminação com DNA genômico, o RNA foi tratado com DNase I (kit turboDNA-free $e^{T M}$, Life Technologies, EUA). Resumidamente, foi adicionado a cada 
amostra, 10\% do volume de 10x Turbo DNase Buffer, $1 \mu \mathrm{L}$ de Turbo DNAse, seguindose incubação de $30 \mathrm{~min}$, a $37^{\circ} \mathrm{C}$. Logo após, foram acrescentados $3 \mu \mathrm{L}$ ou $10 \%$ do volume do reagente de inativação da DNase, seguindo-se incubação de 2 min em temperatura ambiente, período durante o qual as amostras foram agitadas por 2 a 3x. Após centrifugação a 10.000 x g por 2 min, o sobrenadante contendo o RNA foi transferido para um novo eppendorf e a concentração de RNA foi determinada por leitura a $\mathrm{OD}_{260}$ e a qualidade pela razão $\mathrm{OD}_{260} / \mathrm{OD}_{280}$ em espectrofotômetro (NanoDrop ND-1000 Spectrophotometer, NanoDrop, EUA).

A reação de RT-PCR foi realizada com 1 a $4 \mu \mathrm{g}$ de RNA total, utilizando $1 \mu \mathrm{L}$ de oligonucleotídeos randômicos hexâmeros (100 $\eta \mathrm{g} / \mu \mathrm{L})$ e $1 \mu \mathrm{L}$ de dNTP mix $10 \mathrm{mM}$ em reação com volume final de $13 \mu \mathrm{L}$ ajustado com $\mathrm{H}_{2} \mathrm{O}$ DEPC. As amostras foram aquecidas por 5 min a $65^{\circ} \mathrm{C}$ e a seguir transferidas para cuba com gelo, adicionando-se $4 \mu \mathrm{L}$ de tampão para PCR $(5 \mathrm{x}), 1 \mu \mathrm{L}$ de DTT $(0,1 \mathrm{M}), 1 \mu \mathrm{L}$ de inibidor de ribonuclease

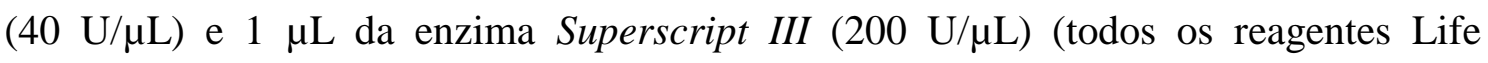
Technologies, EUA), para um volume final de $20 \mu \mathrm{L}$. A mistura foi homogeneizada e, após breve centrifugação, incubada por $5 \min$ a $25^{\circ} \mathrm{C}$, e a seguir por $50 \mathrm{~min}$ a $50^{\circ} \mathrm{C}$. A reação foi inativada por incubação a $70^{\circ} \mathrm{C}$ por 15 min. $\mathrm{O}$ cDNA sintetizado foi utilizado nas reações subsequentes de PCR qualitativo e quantitativo.

\subsection{PCR Quantitativo}

As reações de PCR quantitativo foram feitas através de protocolos distintos. Para protocolo multiplex, foram feitas soluções com um par de primers e uma sonda, específicos para cada um dos genes, Perl, Per2, Bmall e Clock (desenhados pelo programa Primer Quest, IDT, e sintetizados pela IDT, EUA, Tabela 1). Para TrpV1, TrpAl e Ucpl foi usado um par de primers específicos, também desenhados pelo 
programa Primer Quest (Tabela 1), e a amplificação verificada pela incorporação do fluoróforo SYBR Green. Foi utilizado RNA ribossômico 18S como normalizador dos experimentos, com primers desenhados em região altamente conservada (Tabela 1).

Tabela 1 - Seqüências de Primers e Sondas para PCR Quantitativo

\begin{tabular}{|c|c|c|}
\hline \multirow{2}{*}{$\begin{array}{c}\text { Template } \\
\text { Nome }\end{array}$} & Mus musculus & \multirow{2}{*}{$\begin{array}{c}\text { Concentração } \\
\text { final }\end{array}$} \\
\hline & Sequência & \\
\hline \multirow{3}{*}{ mPerl } & For: - AGCAGGTTCAGGCTAACCAGGAAT & $300 \mathrm{nM}$ \\
\hline & Rev: - AGGTGTCCTGGTTTCGAAGTGTGT & $300 \mathrm{nM}$ \\
\hline & $\begin{array}{l}\text { Sonda: - 6FAM- } \\
\text { GCCTTGTGCCATGGACATGTCTACT }\end{array}$ & $200 \mathrm{nM}$ \\
\hline \multirow{3}{*}{ mPer2 } & For: - TTCCTACAGCATGGAGCAGGTTGA T & $300 \mathrm{nM}$ \\
\hline & Rev: - ATGAGGAGCCAGGAACTCCACAAA & $300 \mathrm{nM}$ \\
\hline & $\begin{array}{l}\text { Sonda: 5Cy5- } \\
\text { ACGCGGATATGTTTGCTGTGGCTGT-3BHQ2 }\end{array}$ & $200 \mathrm{nM}$ \\
\hline \multirow{3}{*}{ mBmall } & For: - AAGCTTCTGCACAATCCACAGCAC & $300 \mathrm{nM}$ \\
\hline & Rev:- TGTCTGGCTCATTGTCTTCGTCCA & $300 \mathrm{nM}$ \\
\hline & $\begin{array}{l}\text { Sonda: - 5HEX-A AA GCT GGC CAC CCA } \\
\text { CGAAGATGGG-3BHQ1 }\end{array}$ & $200 \mathrm{nM}$ \\
\hline \multirow{3}{*}{ mClock } & For: - CTCTGCTGCCTTTCCACTACA A & $300 \mathrm{nM}$ \\
\hline & Rev: - TGCTGAGGCTGGTGTTGCT & $300 \mathrm{nM}$ \\
\hline & $\begin{array}{l}\text { Sonda: 5HEX-AGA GCA CTT TCC CTC CTT } \\
\text { CGC ACC A-3BHQ_1 }\end{array}$ & $200 \mathrm{nM}$ \\
\hline
\end{tabular}


MATERIAL E MÉTODOS

\begin{tabular}{|c|c|c|}
\hline \multirow{2}{*}{$m T r p V 1$} & For: - CAGAGACCTGTGTCGGTTTATG & $300 \mathrm{nM}$ \\
\hline & Rev: - CATGTTGAGCAGGAGGATGTAG & $300 \mathrm{nM}$ \\
\hline \multirow{2}{*}{$m \operatorname{TrpAl}$} & For: - GGTCCAACATAACCGCATAGA & $300 \mathrm{nM}$ \\
\hline & Rev: - AGGGCAACACGAAGATGATAC & $300 \mathrm{nM}$ \\
\hline \multirow{2}{*}{$m U c p l$} & For: - CAG CTT GCC TGG CAG ATA TCA & $300 \mathrm{nM}$ \\
\hline & Rev: - TTG GAT CTG AAG GCG GAC TT & $300 \mathrm{nM}$ \\
\hline \multirow{2}{*}{ RNA $18 S$} & For: - CGG CTA CCA CAT CCA AGG AA & $50 \mathrm{nM}$ \\
\hline & Rev: - GCT GGA ATT ACC GCG GCT & $50 \mathrm{nM}$ \\
\hline
\end{tabular}

Para os ensaios de PCR quantitativo através do protocolo multiplex para análise simultânea dos genes Perl, Bmall e RNA 18S ou Per2, Clock e RNA 18S de Mus musculus, foram preparadas soluções contendo os primers $(300 \mathrm{nM}$ para genes de interesse e $50 \mathrm{nM}$ para RNA 18S), sondas (200 nM para genes de interesse e $50 \mathrm{nM}$ para 18S), Supermix 2X (BioRad, EUA) suplementado para 1,6 mM de dNTPS, $6 \mathrm{mM}$ de $\mathrm{MgCl}_{2}, 0,1 \mathrm{U} / \mu \mathrm{L}$ de Platinum Taq DNA polimerase (Life Technologies, Brasil), e $\mathrm{H}_{2} \mathrm{O}$ para volume final de $29 \mu \mathrm{L} /$ poço. Essa solução foi aliquotada ( $87 \mu \mathrm{L}$, sendo cada alíquota suficiente para 3 poços) em tubos, e o cDNA de cada amostra dos diferentes genótipos, tratamentos fotoperiódicos e horas do dia foi adicionado ( $3 \mu \mathrm{L} /$ alíquota) a cada tubo. As soluções já com cDNA foram então distribuídas nos poços da placa de experimento ( $28 \mu \mathrm{L} /$ poço). Controles negativos feitos sem cDNA foram incluídos rotineiramente. 
Para os ensaios de $\operatorname{Trp} V 1$, TrpAl e Ucpl, foram preparadas soluções contendo os primers, SYBR ${ }^{\circledR}$ GreenER ${ }^{\mathrm{TM}}$ qPCR SuperMix for iCycler $^{\circledR}$ 2x (Life Technologies, EUA) e $\mathrm{H}_{2} \mathrm{O}$ DNaseRNase-free (Life Technologies, EUA), obtendo-se uma concentração final de $300 \eta \mathrm{M}$ e 50 ๆM para os primers de cada gene e do RNA 18S, respectivamente, em soluções independentes. Cada solução foi aliquotada (48 $\mu \mathrm{L}$, sendo cada alíquota suficiente para 2 poços) em tubos eppendorf e o cDNA de cada amostra foi adicionado ( $2 \mu \mathrm{L} /$ alíquota). As soluções já com cDNA foram então distribuídas nos poços da placa experimental $(23 \mu \mathrm{L} /$ poço).

O fluoróforo SYBR Green intercala-se ao DNA durante sua amplificação, promovendo um aumento da fluorescência (Nath et al., 2000). O SYBR Green se intercala a qualquer fita de DNA que está sendo amplificada, não sendo específico. Para determinar se houve a amplificação de produtos inespecíficos, foram obtidas melting curves. Durante essa fase, a temperatura é aumentada em $0,5^{\circ} \mathrm{C}$ a intervalos de tempo determinados e a fluorescência dos poços obtida em cada fase. As curvas ideais mostram apenas um pico de queda de fluorescência em cada poço, numa temperatura que coincide com a melting temperature do produto esperado (quando o produto se dissocia). Quando há produtos inespecíficos, sua dissociação forma outro(s) pico(s) de fluorescência em diferentes temperaturas, sendo esses poços imediatamente excluídos da análise.

Todos os ensaios foram realizados nas seguintes condições: para os ensaios de multiplex, em termociclador i5 (BioRad), 7 min a $95^{\circ} \mathrm{C}$ seguido por 45 ciclos de $30 \mathrm{seg}$ a $95^{\circ} \mathrm{C}$ e 1 min a $55^{\circ} \mathrm{C}$, e para os ensaios de $S Y B R$ Green, em termociclador iCycler (Biorad) $2 \min$ a $50^{\circ} \mathrm{C}, 8: 30 \mathrm{~min}$ a $95^{\circ} \mathrm{C}$, seguido por 45 ciclos de $15 \mathrm{seg}$ a $95^{\circ} \mathrm{C}, 1 \mathrm{~min}$ a $60^{\circ} \mathrm{C}, 1 \mathrm{~min}$ a $95^{\circ} \mathrm{C}, 1 \mathrm{~min}$ a $55^{\circ} \mathrm{C}$ e 80 ciclos de $10 \mathrm{seg}$ a $55^{\circ} \mathrm{C}$, com aumento gradativo de $0,5^{\circ} \mathrm{C}$. 
A análise dos dados foi feita pela comparação entre os $\mathrm{C}_{\mathrm{T}} \mathrm{S}$ de pontos temporais de um mesmo genótipo, ou de ambos os genótipos em um mesmo $\mathrm{C}_{\mathrm{T}}$, obtidos entre as porções de crescimento geométrico das curvas, passando-se uma reta denominada limiar que cruza essas porções. Sabendo-se o número de ciclos por onde passa a reta limiar $\left(\mathrm{C}_{\mathrm{T}}\right)$, é encontrado o $\Delta \mathrm{C}_{\mathrm{T}}$ que é a diferença entre esse valor para o gene de interesse e para o RNA 18S. Quando a variação dos valores de $\Delta \mathrm{C}_{\mathrm{T}}$ entre animais do mesmo genótipo e ponto temporal foi maior que 2, esse ponto foi considerado Outlier e não utilizado para cálculo da média.

Para cada órgão, o menor valor de escuro constante (DD) dos animais WT foi subtraído dos pontos temporais ou no mesmo ponto temporal de animais $\mathrm{KO}$, obtendose o $\Delta \Delta \mathrm{C}_{\mathrm{T}}$. Quando comparamos o mesmo gene nos vários órgãos, para obter o $\Delta \Delta \mathrm{C}_{\mathrm{T}}$, utilizamos o menor valor em escuro constante de animais WT entre os órgãos analisados. Colocando-se esse valor como exponencial negativo na base $2\left(2^{-\Delta \Delta \mathrm{CT}}\right)$ obteve-se o número de vezes que o gene está expresso em cada genótipo.

Os valores de log foram obtidos de pelo menos três animais, de dois experimentos independentes e as médias \pm EPM relativas ao menor valor de expressão em DD para cada protocolo foram calculadas e plotadas em gráficos. Para determinar os níveis de significância entre os tempos e os genótipos, os dados logarítmicos foram comparados por one-way ANOVA seguida por teste de Tukey.

Para a comparação de mesmos pontos temporais entre DD e LD, empregou-se a análise de variância two-way ANOVA, seguida pelo pós-teste de Bonferroni. Assumiuse para todos os testes, $\mathrm{p} \leq 0,05$ como probabilidade de rejeição da hipótese nula. 


\section{Resultados}

"Por vezes sentimos que aquilo que fazemos não é senão uma gota de água no mar. Mas o mar seria menor se lhe faltasse uma gota".

Madre Teresa de Calcuta 


\section{Efeito do Pulso de Temperatura em Células B16-F10 Per1::Luc}

Baseando-se na ideia de que a rodopsina possa atuar como um termorreceptor (Shen et al., 2011), o primeiro passo na realização deste trabalho foi a submissão das células B16-F10 Per1::Luc de Mus musculus que, sabidamente expressam essa opsina, a um pulso de temperatura $2,5^{\circ} \mathrm{C}$ acima da temperatura de manutenção, $37^{\circ} \mathrm{C}$.

Nos quatro primeiros dias, as células foram mantidas em DD e, então, esse registro considerado como controle (Figura 8, linha B) do registro dos dias após o pulso (Figura 8, linha D). $\mathrm{O}$ tempo do controle foi redimensionado para que $\mathrm{t}=0$ correspondesse a $24 \mathrm{~h}$ após o início da leitura, uma vez que a troca de meio para o tratamento com luciferina induz um pico inicial na transcrição de Perl (Figura 8, linha A). A leitura do momento em que as placas foram removidas do aparelho para serem submetidas ao pulso de temperatura foi descartada (Figura 8, linha C).

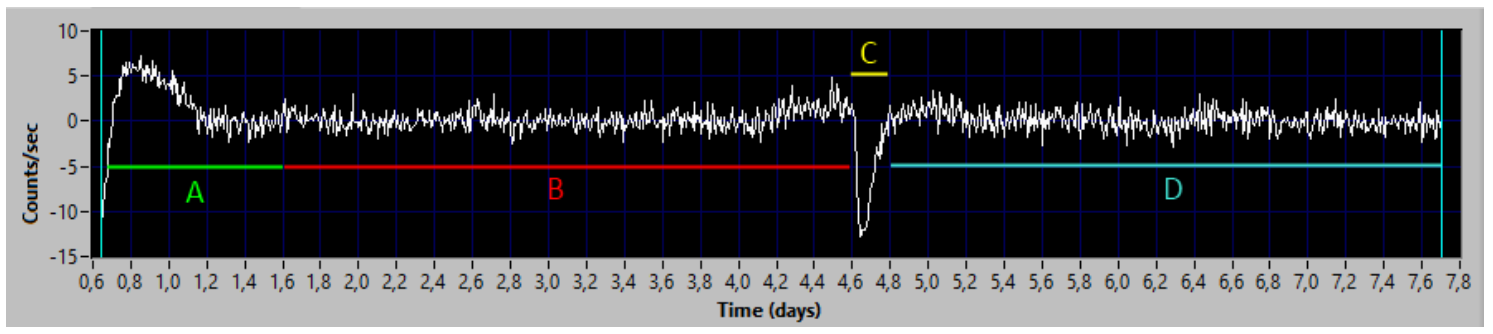

Figura 8. Leitura Típica da Bioluminescência Registrada pelo Programa Lumicycle Analysis ${ }^{\circledR}$, em Melanócitos B16-F10 Per1::Luc Mantidos em DD. Linha verde (A) indica os valores descartados devido a troca de meio; linha vermelha (B) demonstra os valores considerados como controle; linha amarela $(\mathrm{C})$ representa o momento em que as placas foram retiradas do aparelho; linha azul (D) indica os valores considerados após o pulso de temperatura.

Com a análise da bioluminescência emitida pelas células clone, podemos observar que entre os diferentes controles, os períodos variaram de 14,3 a 50 h (Tabela 3). Embora as células do grupo controle não apresentassem uma oscilação circadiana, foi possível observar uma variação da transcrição de Perl nesta condição (Figura 9). 
Após o pulso de $39,5^{\circ} \mathrm{C}$, constatamos a sincronização das células B16-F10 Per1::Luc em DD, imprimindo um ritmo circadiano (períodos entre 20 e 28 h) não observado no controle (Tabela 3). A Figura 9 é representativa para esse resultado, pois demonstra o perfil rítmico para uma das 8 placas analisadas. Comparação gráfica das células controle e após o estímulo por temperatura demonstra de forma clara que o aumento de $2,5^{\circ} \mathrm{C}$ antecipou o pico de expressão do gene analisado, como representado no Inserto da Figura 9.

Tabela 3. Períodos dos Ritmos em Células Controle e após o Pulso de Temperatura

\begin{tabular}{|c|c|c|}
\hline & Controle & Tratado \\
\hline Placa 1 & 31,70 & 24,20 \\
\hline Placa 2 & 27,70 & 22,10 \\
\hline Placa 3 & 50,00 & 27,30 \\
\hline Placa 4 & 19,30 & 21,60 \\
\hline Placa 5 & 17,50 & 22,40 \\
\hline Placa 6 & 14,30 & 20,60 \\
\hline Placa 7 & 27,20 & 24,30 \\
\hline Placa 8 & 36,80 & 22,70 \\
\hline
\end{tabular}




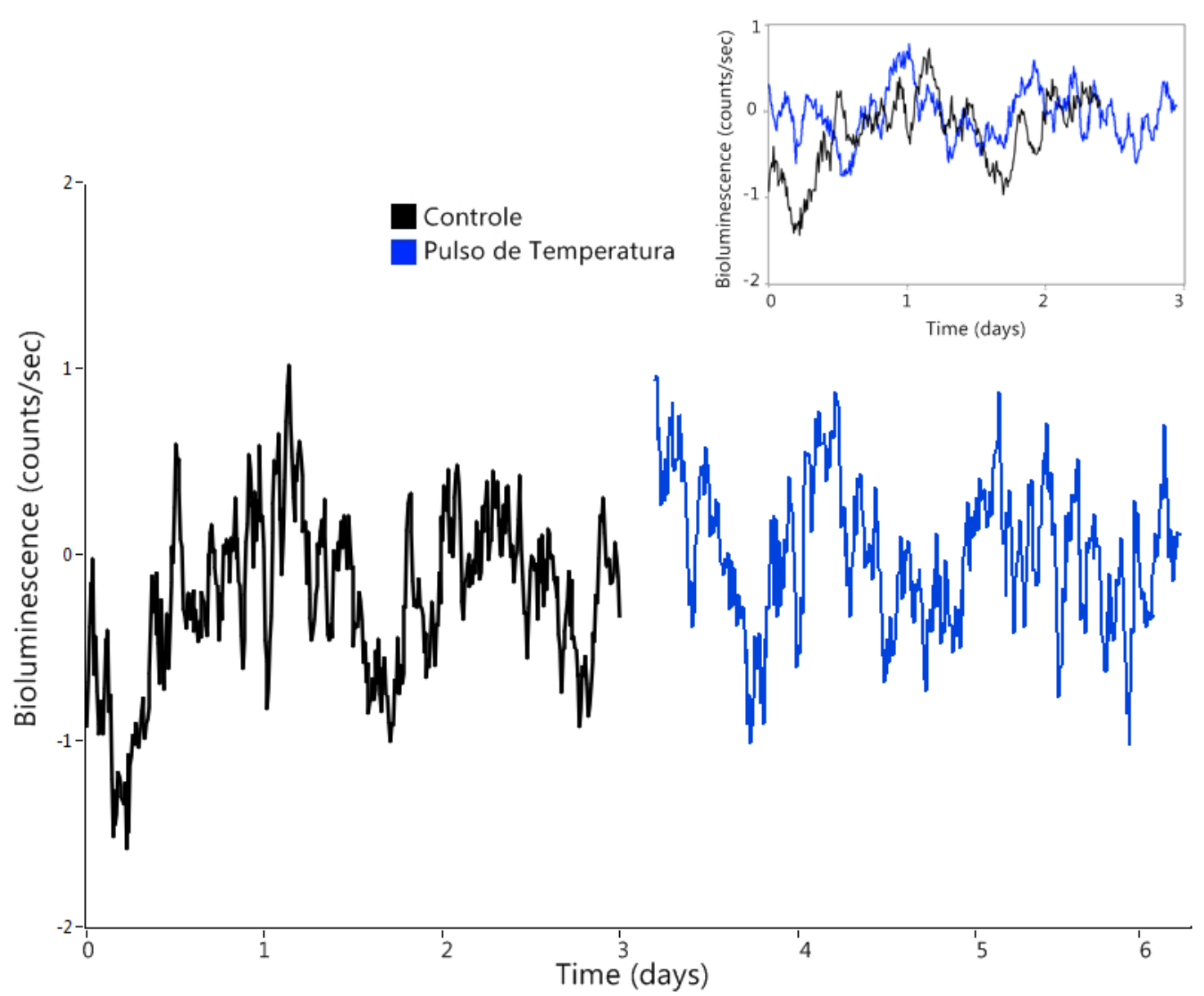

Figura 9. Expressão Gênica de Per1 Registrada pelo Programa Lumicycle Analysis®, em Melanócitos B16-F10 Per1::Luc Mantidos em DD. Linha preta: controle; linha azul: mesmas células após pulso de temperatura, $\mathrm{t}=0$ ajustado para $24 \mathrm{~h}$ após o início da leitura. Interrupção entre as linhas marca o momento do pulso de temperatura. Inserto: gráfico mostrando registros controle e após o pulso, sobrepostos para melhor visualização das diferenças.

\section{Efeito do Pulso de Luz em Células B16-F10 Per1::Luc}

É um conhecimento consolidado que mamíferos só percebem luz através da retina; sabemos, no entanto, que melanócitos cutâneos de mamífero expressam o fotopigmento rodopsina (classicamente envolvida na visão noturna). Dados recentes de nosso laboratório demonstraram, entretanto, que a estimulação por luz branca não altera a expressão dos genes do relógio (Assis et al., 2015) nessas células. Como identificamos a presença do gene e proteína da melanopsina (Moraes et al., 2015) nessa 
mesma linhagem, investigamos a resposta do gene Perl a um pulso de luz de LED azul (comprimento de onda que maximamente estimula a melanopsina, $450-475 \mathrm{~nm}$ ) com intensidade de 650 lux $\left(95,17 \mu\right.$ watts $\left./ \mathrm{cm}^{2}\right)$, durante $10 \mathrm{~min}$.

Como no protocolo anterior, o registro nos quatro primeiros dias desse experimento, quando as células estavam em escuro constante (DD), foi considerado como controle do registro nos dias após o pulso de luz e, também, o tempo do controle foi redimensionado para que $\mathrm{t}=0$ correspondesse a $24 \mathrm{~h}$ após o início da leitura.

A análise da expressão de Perl::Luc demonstrou que, tanto no controle quanto após o pulso de luz, as células mantiveram seu ritmo de transcrição em livre curso, como pode ser observado na Tabela 4, indicando que a luz azul, nas condições usadas, não interferiu na expressão deste gene. A Figura 10 é representativa para esse resultado, pois ilustra o perfil descrito acima para uma das 8 placas analisadas.

Diferente do que foi observado para o pulso de temperatura (Figura 9), nenhuma alteração da bioluminescência foi verificada após o pulso de luz em comparação com as células mantidas em DD (Inserto da Figura 10).

Tabela 4. Períodos dos Ritmos em Células Controle e após o Pulso de Luz Azul

\begin{tabular}{|c|c|c|}
\hline & Controle & Tratado \\
\hline Placa 1 & 22,90 & 21,30 \\
\hline Placa 2 & 10,60 & 14,30 \\
\hline Placa 3 & 14,50 & 14,70 \\
\hline Placa 4 & 21,80 & 19,50 \\
\hline Placa 5 & 22,20 & 20,00 \\
\hline Placa 6 & 22,50 & 19,90 \\
\hline Placa 7 & 22,00 & 19,50 \\
\hline Placa 8 & 10,50 & 12,50 \\
\hline
\end{tabular}




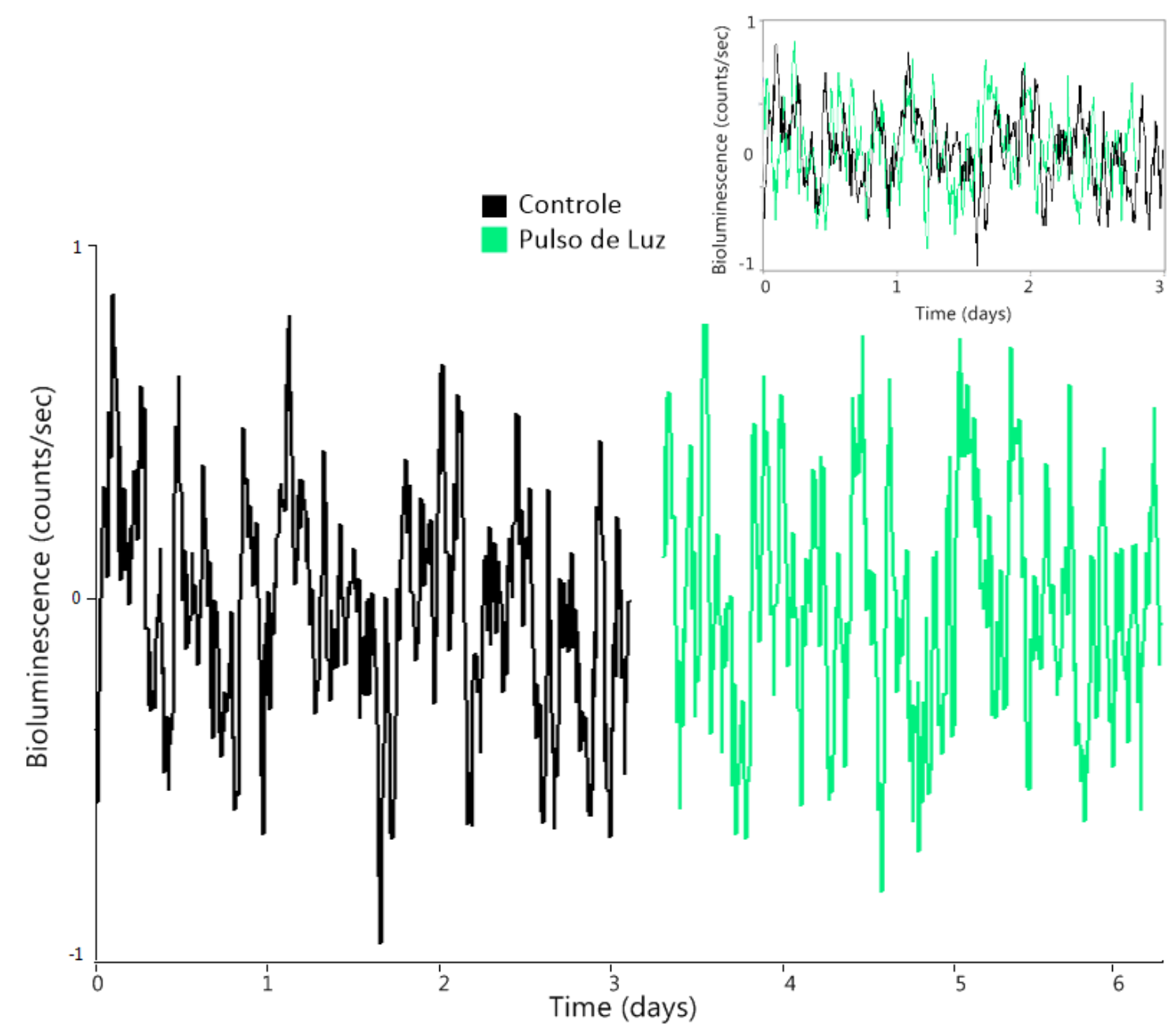

Figura 10. Expressão Gênica de Per1 Registrada pelo Programa Lumicycle Analysis®, em Melanócitos B16-F10 Per1::Luc Mantidos em DD. Linha preta: controle; linha verde: mesmas células após pulso de luz, $\mathrm{t}=0$ ajustado para 24 h após o início da leitura. Interrupção entre as linhas marca o momento do pulso de luz. Inserto: gráfico mostrando registros controle e após o pulso, sobrepostos para melhor visualização.

\section{Quantificação Gênica em Glândula Suprarrenal, Fígado e Tecido Adiposo}

\section{Marrom de Mus musculus Submetidos in vivo a Diferentes Protocolos de Luz}

A hipótese inicial deste trabalho era que, em tecidos periféricos de mamíferos em cultura que expressam opsinas, o sinal de luz, por via direta, poderia estar atuando como um sincronizador da expressão dos genes do relógio, assim como em vertebrados ectotérmicos. Entretanto, identificamos que o papel destas opsinas não está relacionado 
a percepção de luz e, com isso, hipotetizamos que a luz sinalizaria aos tecidos periféricos através de uma via indireta, onde a informação de luz, via NSQ, levaria ao controle da temperatura circadiana que, por sua vez, poderia atuar como uma pista interna para a sincronização dos tecidos periféricos.

Para responder esta questão, utilizamos camundongos submetidos a diferentes protocolos de luz e avaliamos a expressão de genes de relógio em tecidos periféricos. Como citado na sessão de Material e Métodos, os protocolos in vivo foram realizados na Universidade de Virginia pela Profa. Ana Maria Castrucci. Neste trabalho, cabe a apresentação dos resultados obtidos in vitro, por mim, na Universidade de São Paulo.

Foram usados espécimes machos de Mus musculus selvagens (WT) e nocautes (KO) para o canal $\operatorname{Trp} V 1$, uma vez que esse canal está ligado à regulação da temperatura corporal e, ainda, a literatura aponta uma interessante convergência das vias de sinalização da fotorrecepção e termorregulação para canais TRP. Para todos os animais utilizados nestes pacotes experimentais, fez-se inicialmente PCR quantitativo para o gene $\operatorname{Tr} V V 1$, confirmando que os animais nocautes para $\operatorname{Tr} p V 1$ efetivamente não expressavam este canal.

\subsection{Expressão dos Genes de Relógio em Glândula Suprarrenal de Mus} musculus

Análise da expressão de Perl (Figura 11A), Per2 (Figura 12A), Clock (Figura 13A) e Bmall (Figura 14A) na glândula suprarrenal demonstrou não haver diferenças temporais em animais mantidos em DD. Em LD, mais uma vez, nenhuma oscilação foi observada na transcrição dos genes Perl (Figura 11B), Clock (Figura 13B) e Bmall (Figura 14B). No entanto, ao analisarmos a expressão do gene Per2 em LD, observamos uma variação temporal nos animais $\operatorname{Tr} p V 1 \mathrm{KO}$, com pico de expressão na fase escura e, também, uma diferença entre os genótipos nessa mesma fase. (Figura 12B). 
Per1

(A)

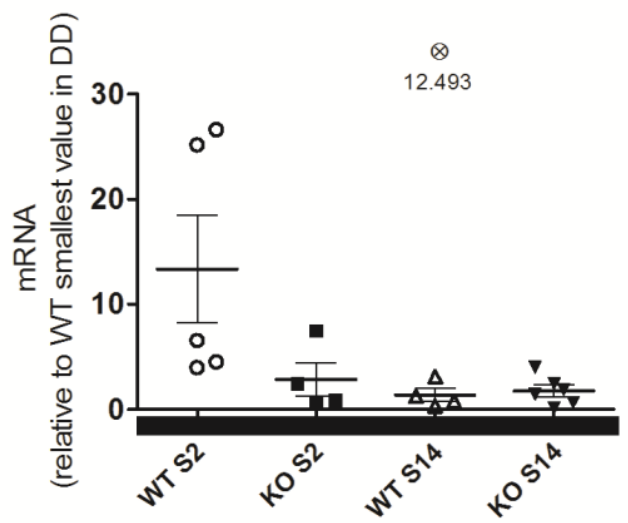

(B)

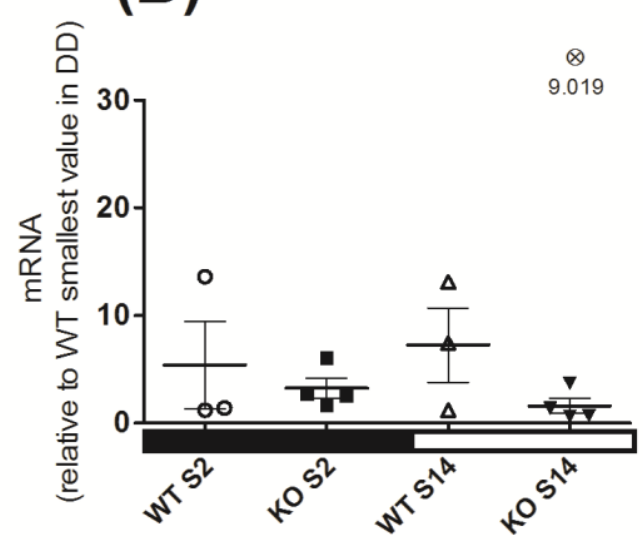

Figura 11. Expressão Gênica de Per1 por PCR Quantitativo em Glândula Suprarrenal de Animais WT e TrpV1 KO. Animais mantidos em (A) escuro constante (DD); (B) ciclo claroescuro (12:12 LD). Os animais foram sacrificados 2 (S2, CT14) e 14 (S14, CT2) horas após o início da atividade locomotora em DD e LD nesta e nas figuras seguintes. Os valores são apresentados como a média $(\mathrm{n}=3-6) \pm$ EPM de expressão de Perl normalizado por RNA 18S e expressos relativos ao menor valor de WT em DD. Análise estatística utilizada: one-way ANOVA seguida de teste de Tukey. Outlier no valor de 12.493 está indicado em (A) e 9.019 em (B) como um círculo cruzado.

\section{Per2}

(A)

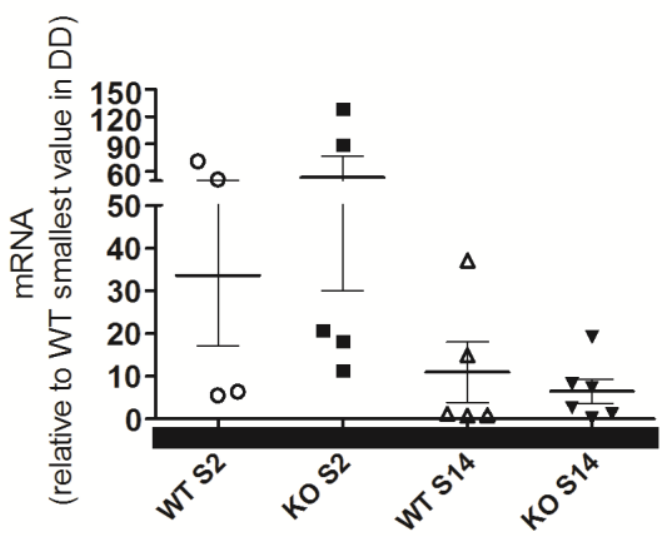

(B)

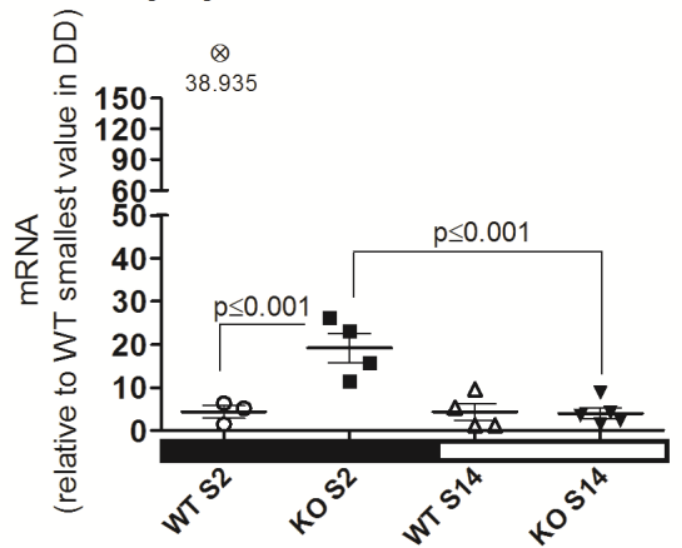

Figura 12. Expressão Gênica de Per2 por PCR Quantitativo em Glândula Suprarrenal de Animais WT e TrpV1 KO. Animais mantidos em (A) escuro constante (DD); (B) ciclo claro- 
escuro (12:12 LD). Os valores são apresentados como a média $(n=3-6) \pm$ EPM de expressão de Per2 normalizado por RNA $18 \mathrm{~S}$ e expressos relativos ao menor valor de WT em DD. Análise estatística utilizada: one-way ANOVA seguida de teste de Tukey. Outlier no valor de 38.935 está indicado em (B) como um círculo cruzado.

\section{Clock}

(A)

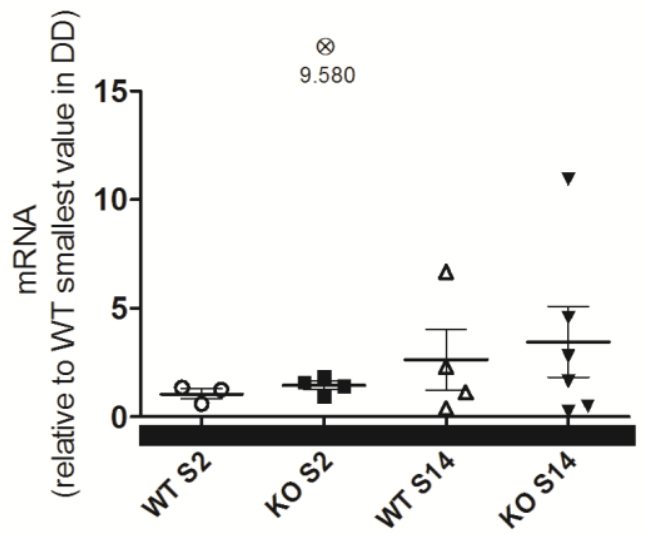

(B)

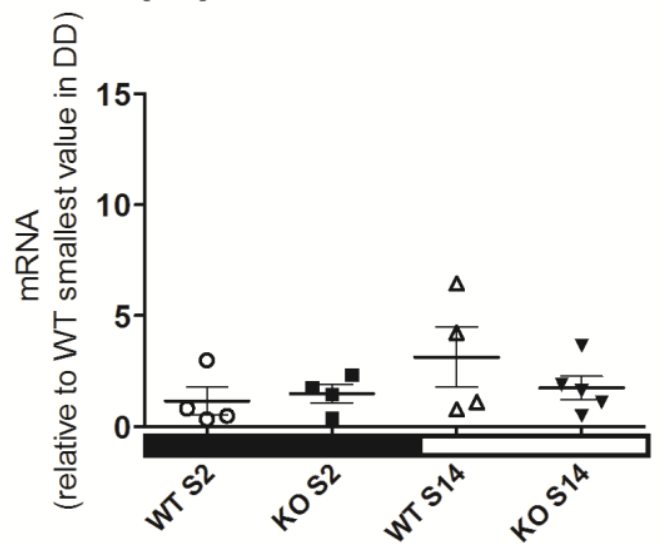

Figura 13. Expressão Gênica de Clock por PCR Quantitativo em Glândula Suprarrenal de Animais WT e TrpV1 KO. Animais mantidos em (A) escuro constante (DD); (B) ciclo claroescuro (12:12 LD). Os valores são apresentados como a média $(n=3-6) \pm$ EPM de expressão de Per2 normalizado por RNA $18 \mathrm{~S}$ e expressos relativos ao menor valor de WT em DD. Análise estatística utilizada: one-way ANOVA seguida de teste de Tukey. Outlier no valor de 9.580 está indicado em (A) como um círculo cruzado.

\section{Bmal1}

(A)

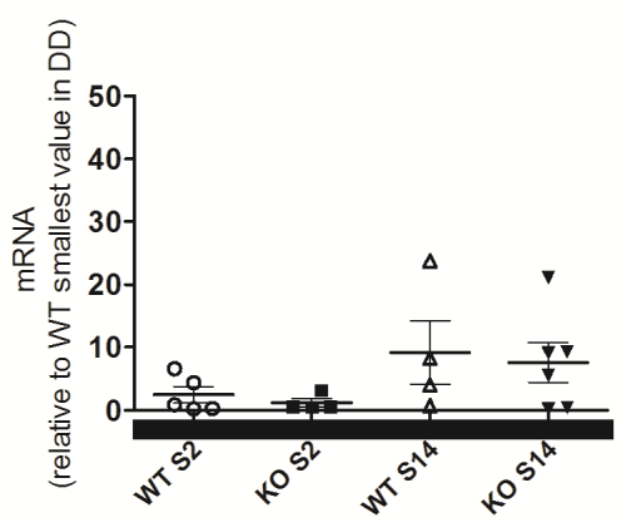

(B)

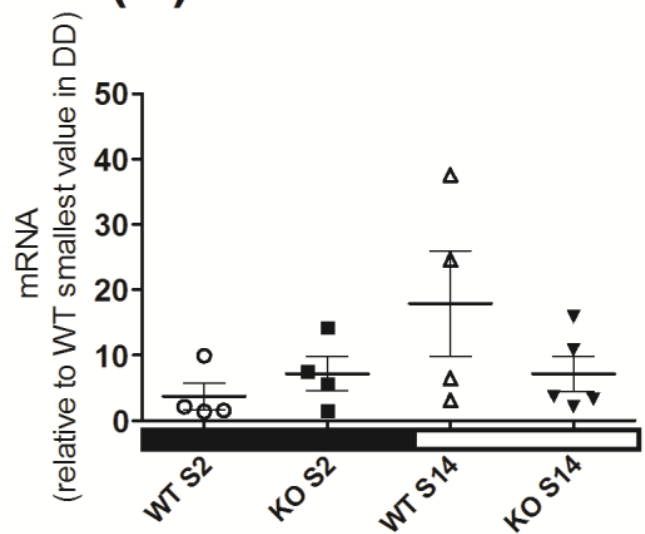

Figura 14. Expressão Gênica de Clock por PCR Quantitativo em Glândula Suprarrenal 
de Animais WT e TrpV1 KO Animais mantidos em (A) escuro constante (DD); (B) ciclo claro-escuro (12:12 LD). Os valores são apresentados como a média $(n=4-6) \pm$ EPM de expressão de Per2 normalizado por RNA $18 \mathrm{~S}$ e expressos relativos ao menor valor de WT em DD. Análise estatística utilizada: one-way ANOVA seguida de teste de Tukey.

Para analisarmos o efeito do ciclo claro-escuro sobre a expressão dos genes do relógio, comparamos os protocolos de DD e LD através da análise estatística two-away ANOVA, seguida de pós-teste Bonferroni, com significância para $\mathrm{p} \leq 0,05$. Na glândula suprarrenal, não houve diferença significativa para nenhum dos genes em ambos os genótipos.

\subsection{Expressão dos Genes de Relógio em Fígado de Mus musculus}

No fígado, os níveis de RNAm de Perl mostraram uma oscilação temporal em DD nos animais WT, com um pico de maior expressão na fase de escuro subjetivo (S2) (Figura 15A). Quando analisamos os níveis dos transcritos em animais mantidos em LD, nenhuma mudança temporal ou entre os genótipos foi observada (Figura 15B).

\section{Per1}

(A)



(B)

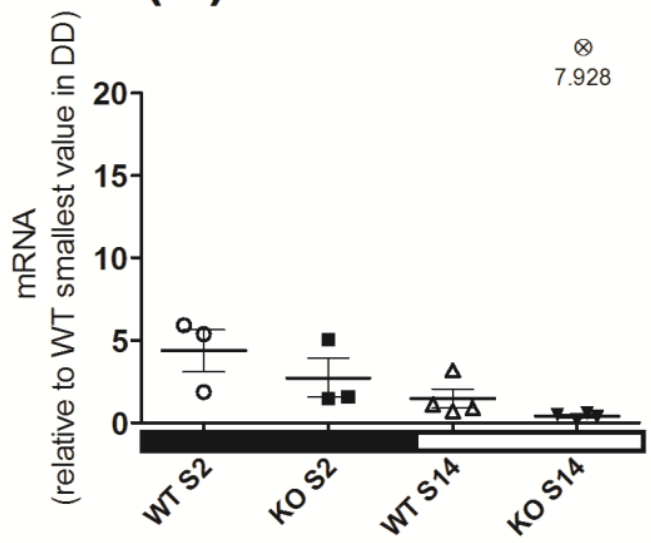

Figura 15. Expressão Gênica de Perl por PCR Quantitativo em Fígado de Animais WT e

TrpV1 KO. Animais mantidos em (A) escuro constante (DD); (B) ciclo claro-escuro (12:12 
LD). Os valores são apresentados como a média $(n=4-6) \pm$ EPM de expressão de Per2 normalizado por RNA $18 \mathrm{~S}$ e expressos relativos ao menor valor de WT em DD. Análise estatística utilizada: one-way ANOVA seguida de teste de Tukey. Outlier no valor de 7.928 está indicado em (B) como um círculo cruzado.

A expressão do gene Per2 de animais WT ou KO mantidos em DD não apresentou variação estatisticamente significativa (Figura 16A); por outro lado, em LD, podemos observar uma oscilação temporal marcante na expressão deste gene, em animais WT e TrpVI KO, ambos os genótipos com pico de expressão na fase escura e, desse modo, não apresentando diferença estatística entre eles (Figura 16B).

\section{Per2}

(A)

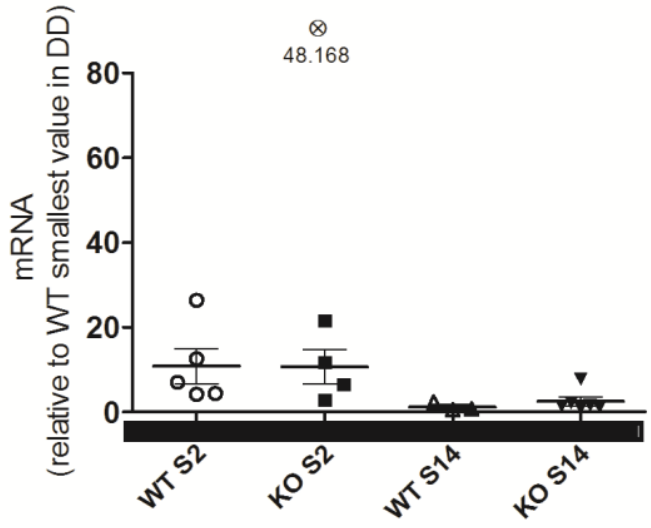

(B)

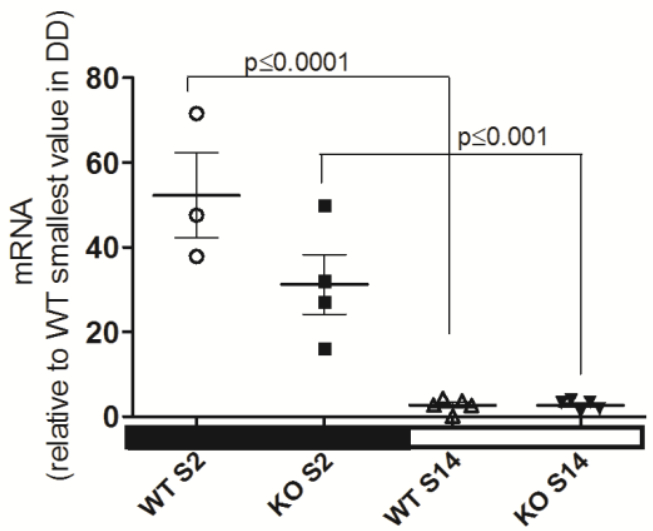

Figura 16. Expressão Gênica de Per2 por PCR Quantitativo em Fígado de Animais WT e TrpV1 KO. Animais mantidos em (A) escuro constante (DD); (B) ciclo claro-escuro (12:12 LD). Os valores são apresentados como a média $(n=4-6) \pm$ EPM de expressão de Per2 normalizado por RNA $18 \mathrm{~S}$ e expressos relativos ao menor valor de WT em DD. Análise estatística utilizada: one-way ANOVA seguida de teste de Tukey. Outlier no valor de 41.168 está indicado em (A) como um círculo cruzado.

Nenhuma oscilação ao longo do dia ou entre animais WT e TrpV1 KO foi observada na expressão de Clock (Figura 17A e B). 


\section{Clock}

(A)

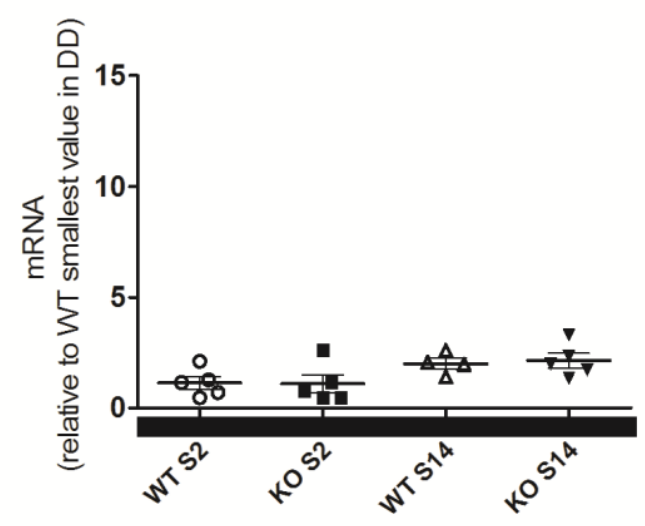

(B)

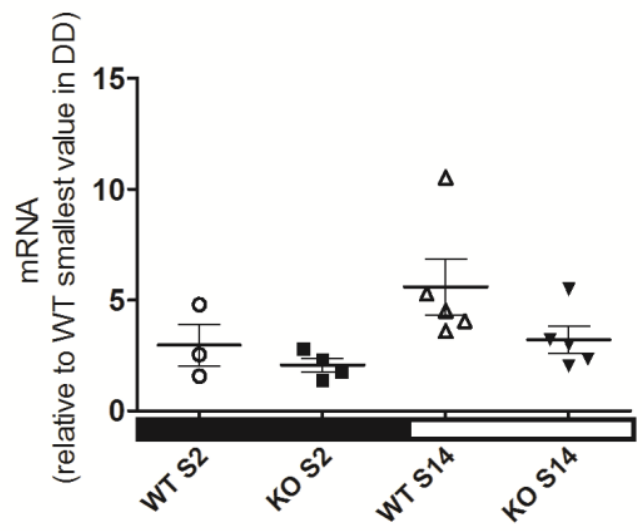

Figura 17. Expressão Gênica de Clock por PCR Quantitativo em Fígado de Animais WT e

TrpV1 KO. Animais mantidos em (A) escuro constante (DD); (B) ciclo claro-escuro (12:12 LD). Os valores são apresentados como a média $(n=4-6) \pm$ EPM de expressão de Per2 normalizado por RNA $18 \mathrm{~S}$ e expressos relativos ao menor valor de WT em DD. Análise estatística utilizada: one-way ANOVA seguida de teste de Tukey.

Diferentemente dos genes anteriores, a expressão do gene Bmall oscilou em ambas as condições DD e LD, com maior expressão durante a fase de claro, subjetivo no caso de DD (Figura 18A e B). Ainda nessa fase, identificamos que, em animais submetidos a ciclo claro-escuro, a expressão deste gene foi significativamente inferior na ausência do canal TrpVI em comparação a animais WT (Figura 18B); este efeito pode ser atribuído a ação do ciclo claro-escuro que induziu um aumento na expressão de Bmall em animais WT na fase clara, quando comparado a sua expressão em DD nesse mesmo ponto (Tabela 5). 


\section{Bmal1}

(A)

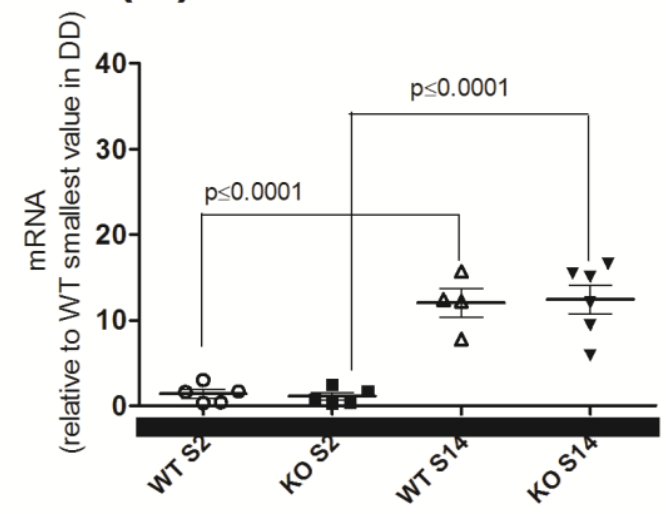

(B)

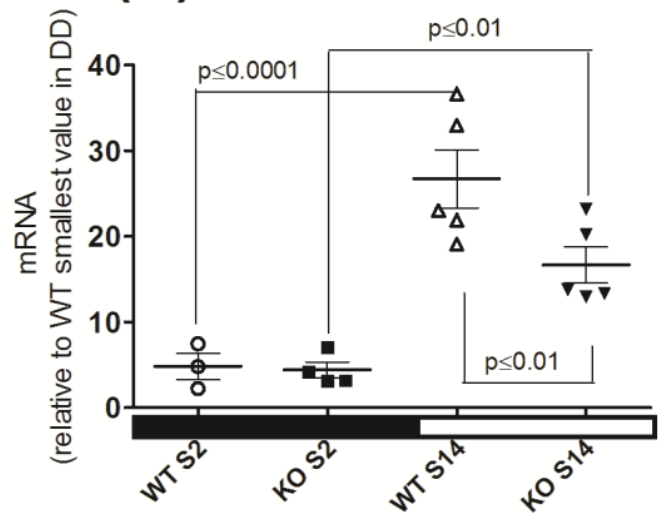

Figura 18. Expressão Gênica de Bmal1 por PCR Quantitativo em Fígado de Animais WT e TrpV1 KO. Animais mantidos em (A) escuro constante (DD); (B) ciclo claro-escuro (12:12 LD). Os valores são apresentados como a média $(n=4-6) \pm$ EPM de expressão de Per2 normalizado por RNA $18 \mathrm{~S}$ e expressos relativos ao menor valor de WT em DD. Análise estatística utilizada: one-way ANOVA seguida de teste de Tukey.

Os valores em LD que se mostraram significativamente diferentes daqueles em DD (two-away ANOVA, seguida de pós-teste Bonferroni; significância para $\mathrm{p} \leq 0,05$ ), em fígado de Mus musculus, encontram-se na Tabela 5. É importante destacar que o ciclo claro-escuro atuou sobre a expressão dos genes Perl e Per2 de forma oposta: inibiu drasticamente a expressão de Perl e aumentou a expressão de Per2 em S2 (fase escura) nos animais WT (Tabela 5). Já o efeito do ciclo claro-escuro sobre a expressão dos genes Clock e Bmall ocorreu de forma similar, em ambos, um aumento da transcrição durante a fase clara (S14), também em animais WT (Tabela 5). 
RESULTADOS

Tabela 5. Valores Significativamente Diferentes entre LD e DD Obtidos para Genes de Relógio no Fígado e sua Análise por Two-away ANOVA

\begin{tabular}{|c|c|c|c|c|c|}
\hline Gene & Genótipo & Circadian Time & DD & LD & ANOVA \\
\hline Per1 & WT & CT14 (S2) & $16,32 \pm 1,59$ & $4,39 \pm 1,27$ & $\mathrm{p} \leq 0,01$ \\
\hline Per2 & WT & CT14 (S2) & $10,89 \pm 4,15$ & $52,27 \pm 10,02$ & $\mathrm{p} \leq 0,001$ \\
\hline Clock & WT & CT2 (S14) & $2,04 \pm 0,16$ & $5,60 \pm 1,26$ & $\mathrm{p} \leq 0,01$ \\
\hline Bmal1 & WT & CT2 (S14) & $12,04 \pm 1,62$ & $26,72 \pm 3,40$ & $\mathrm{p} \leq 0,001$ \\
\hline
\end{tabular}

\subsection{Expressão dos Genes de Relógio em Tecido Adiposo Marrom de Mus}

musculus

Para todos os animais utilizados neste pacote experimental, fez-se inicialmente PCR quantitativo para termogenina ou Ucpl (Uncoupling Protein 1) no tecido adiposo extraído, confirmando que o material coletado era realmente tecido adiposo marrom (Figura 19). A Ucpl está diretamente ligada à termogênese do tecido adiposo marrom e observamos que em DD, esse gene não demonstra variação temporal em sua expressão (Figura 19A). No entanto, em LD notamos que, durante a fase escura, sua expressão foi maior em animais selvagens do que nos TrpVI KO. Ainda nesta condição, identificamos diferenças significativas na expressão temporal deste gene nos animais TrpVl KO, com pico na fase clara (Figura 19B). 


\section{Ucp1}

(A)

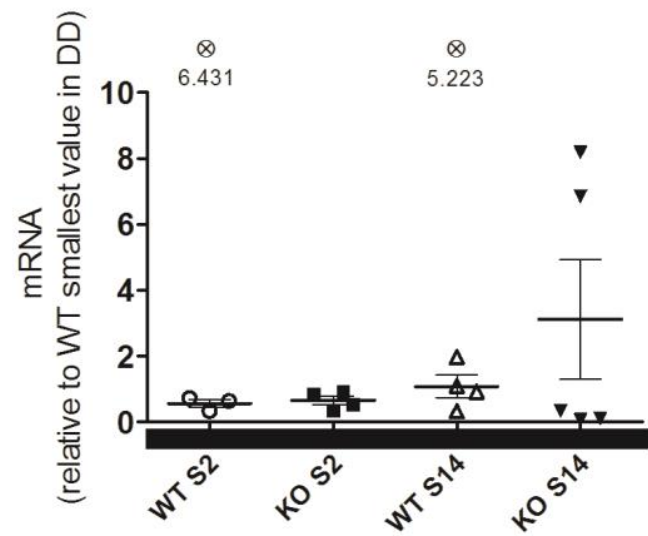

(B)

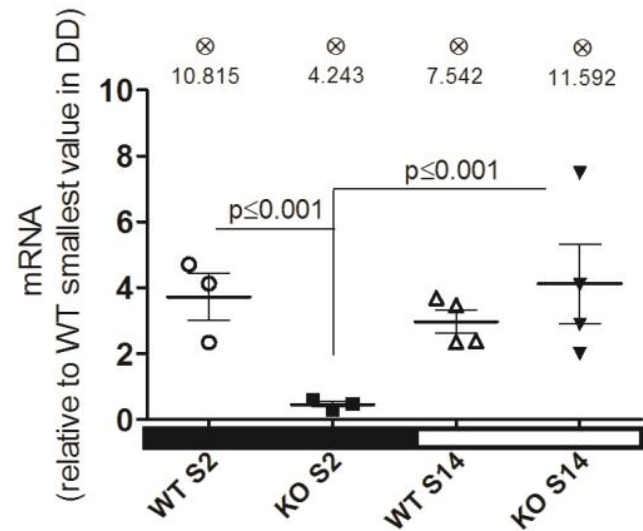

Figura 19. Expressão Gênica de UCP1 por PCR Quantitativo em Tecido Adiposo Marrom de Animais WT e TrpV1 KO. Animais mantidos em (A) escuro constante (DD); (B) ciclo claro-escuro (12:12 LD). Os valores são apresentados como a média $(n=4-5) \pm$ EPM de expressão de Per2 normalizado por RNA $18 \mathrm{~S}$ e expressos relativos ao menor valor de WT em DD. Análise estatística utilizada: one-way ANOVA seguida de teste de Tukey. Outliers no valor de 6.431 e 5.223 estão indicados em (A) e de 10.815, 4.243, 7.542 e 11.592 indicados em (B) como círculos cruzados.

Neste tecido obtido de animais mantidos em DD, os genes Perl e Per2 não apresentaram variações temporais ou diferenças entre os genótipos (Figura 20A e 21A). Em LD, o perfil de transcrição de Perl (Figura 20B) e Per2 (Figura 21B) foi similar: um pico de expressão foi observado durante a fase escura (S2) em animais selvagens nestes dois genes; na ausência do canal TRPV1 essa oscilação foi perdida, devido a redução do RNAm em S2, chegando a níveis muito baixos, próximos aos encontrados em S14 (fase de repouso). 


\section{Per1}

(A)

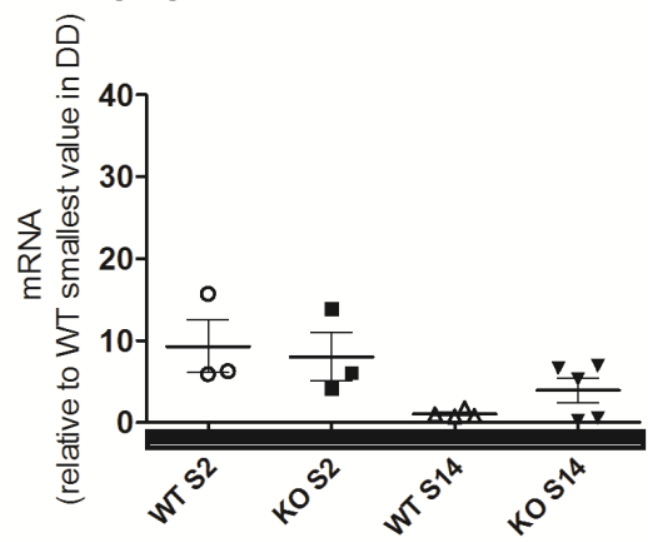

(B)

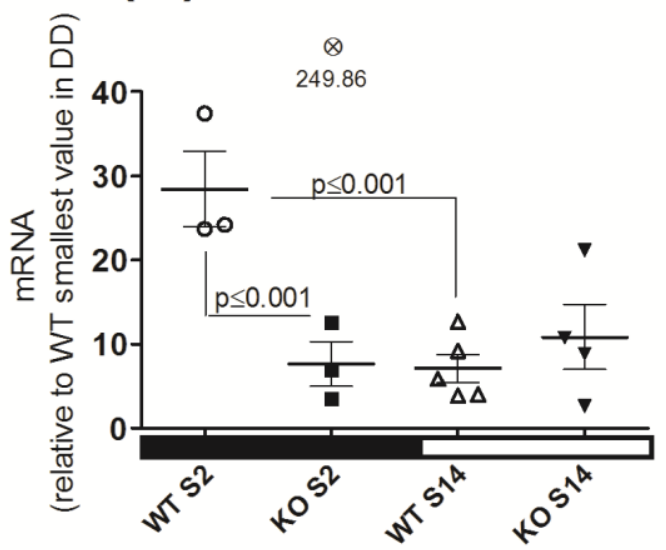

Figura 20. Expressão Gênica de Perl por PCR Quantitativo em Tecido Adiposo Marrom de Animais WT e TrpV1 KO. Animais mantidos em (A) escuro constante (DD); (B) ciclo claro-escuro (12:12 LD). Os valores são apresentados como a média $(n=3-5) \pm$ EPM de expressão de Per2 normalizado por RNA $18 \mathrm{~S}$ e expressos relativos ao menor valor de WT em DD. Análise estatística utilizada: one-way ANOVA seguida de teste de Tukey. Outlier no valor de 249.86 está indicado em (B) como um círculo cruzado.

\section{Per2}

(A)

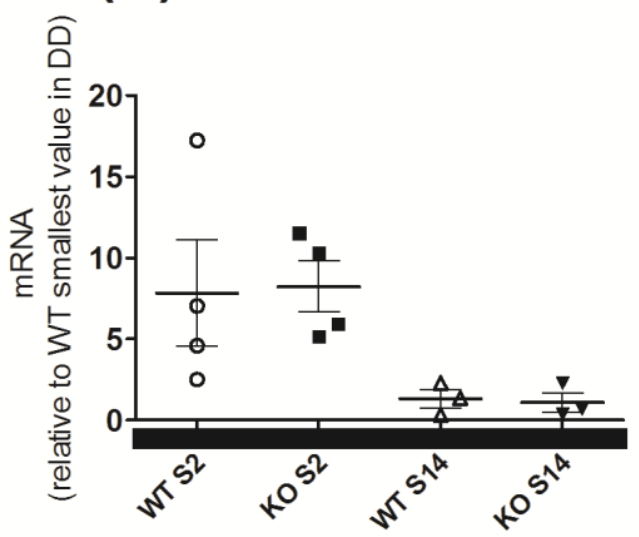

(B)

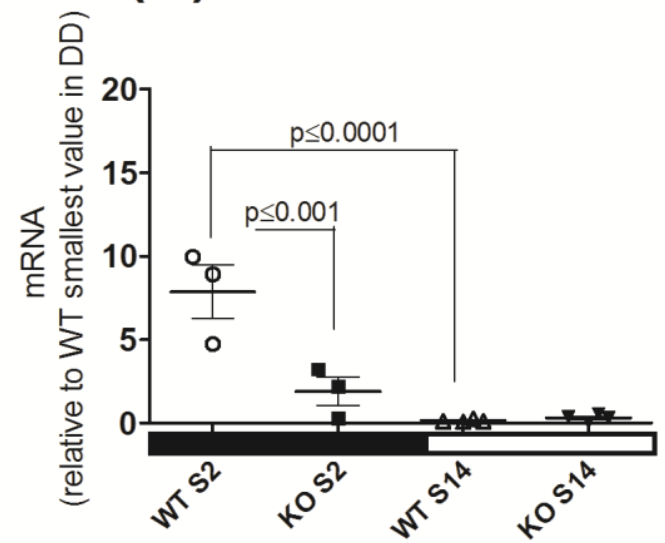

Figura 21. Expressão Gênica de Per2 por PCR Quantitativo em Tecido Adiposo Marrom de Animais WT e TrpVI KO. Animais mantidos em (A) escuro constante (DD); (B) ciclo claro-escuro (12:12 LD). Os valores são apresentados como a média $(n=3-5) \pm$ EPM de 
expressão de Per2 normalizado por RNA $18 \mathrm{~S}$ e expressos relativos ao menor valor de WT em DD. Análise estatística utilizada: one-way ANOVA seguida de teste de Tukey.

Nenhuma oscilação foi observada em DD na expressão do gene Clock (Figura 22A). Em LD, nenhuma oscilação temporal foi vista para os animais WT, enquanto que nos animais $\operatorname{Trp} V 1 \mathrm{KO}$ foi identificada uma variação temporal com pico de expressão na fase clara. Podemos afirmar que esse aumento na expressão de Clock, em animais nocaute durante a fase clara, ocorreu devido à presença do ciclo claro-escuro, uma vez que esse valor de expressão é significativo quando comparado ao DD (Tabela 6). Nenhuma variação entre os genótipos, na mesma fase, foi constatada (Figura 22B).

\section{Clock}

(A)

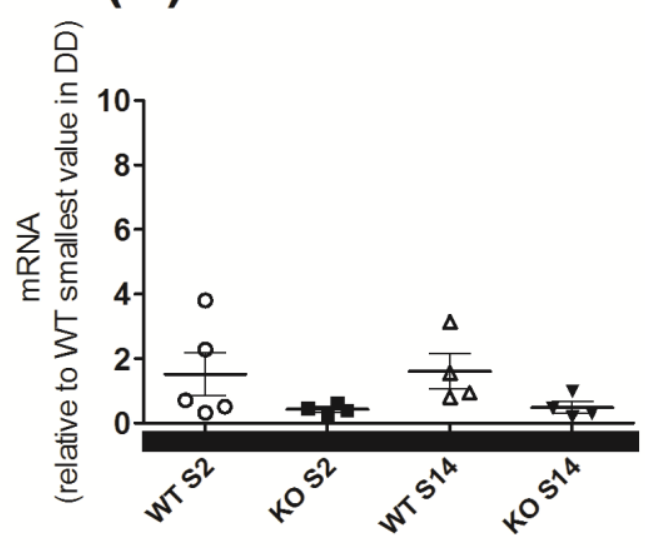

(B)

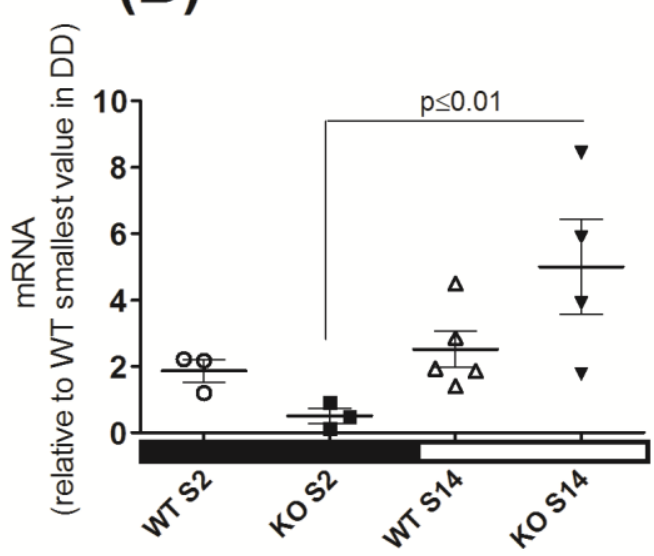

Figura 22. Expressão Gênica de Clock por PCR Quantitativo em Tecido Adiposo Marrom de Animais WT e TrpV1 KO. Animais mantidos em (A) escuro constante (DD); (B) ciclo claro-escuro (12:12 LD). Os valores são apresentados como a média $(n=3-4) \pm$ EPM de expressão de Per2 normalizado por RNA $18 \mathrm{~S}$ e expressos relativos ao menor valor de WT em DD. Análise estatística utilizada: one-way ANOVA seguida de teste de Tukey.

A expressão de Bmal1 em animais selvagens mantidos em DD apresentou uma variação entre os tempos, com maior expressão na fase clara subjetiva em relação a fase 
de escuro subjetivo. Ao compararmos animais WT e TrpVI KO, temos na fase clara subjetiva uma diferença significativa na expressão desse gene, onde animais selvagens apresentam um maior nível de transcritos (Figura 23A). Por outro lado, animais selvagens mantidos em LD apresentaram uma expressão constante para Bmall, enquanto que animais nocaute exibiram uma oscilação com maior expressão durante a fase de repouso (Figura 23B).

\section{Bmal1}

(A)

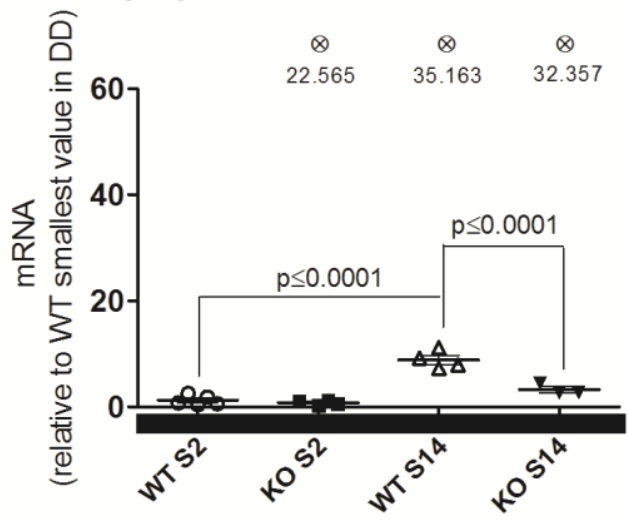

(B)

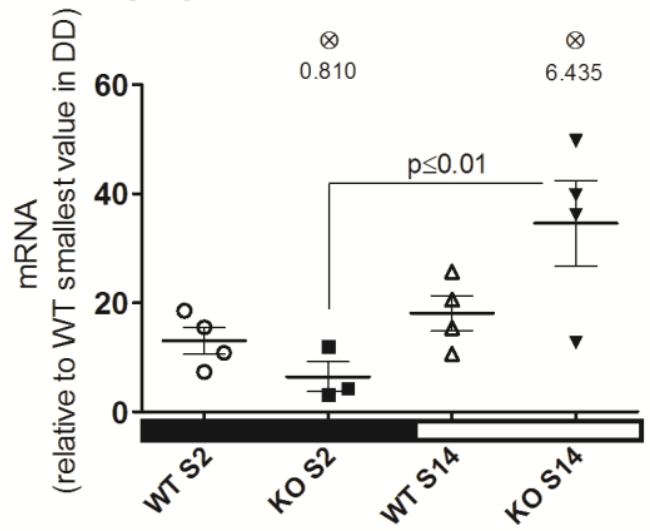

Figura 23. Expressão Gênica de Bmal1 por PCR Quantitativo em Tecido Adiposo Marrom de Animais WT e TrpV1 KO. Animais mantidos em (A) escuro constante (DD); (B) ciclo claro-escuro (12:12 LD). Os valores são apresentados como a média $(n=4-5) \pm$ EPM de expressão de Per2 normalizado por RNA $18 \mathrm{~S}$ e expressos relativos ao menor valor de WT em DD. Análise estatística utilizada: one-way ANOVA seguida de teste de Tukey. Outliers nos valores de 22.565, 35.163, 32.357 estão indicados em (A) e 0.810 e 6.435 em (B) como círculos cruzados.

Os valores para os genes do relógio analisados em tecido adiposo marrom de Mus musculus, que se mostraram significativamente diferentes em LD daqueles em DD (two-away ANOVA, seguida do pós-teste Bonferroni, com nível de significância para $\mathrm{p}<0,05)$, encontram-se na Tabela 6. Destacamos o forte aumento na expressão do gene Perl na fase escura do ciclo claro-escuro em animais WT, e também o aumento na 
expressão de Clock e Bmall na fase clara em animais TrpV1 KO mantidos em LD. Ainda é possível observar uma forte redução na expressão do gene Per2 em animais nocaute, durante a fase escura de $\mathrm{LD}$, quando comparado a DD.

Tabela 6. Valores Significativamente Diferentes entre LD e DD Obtidos para Genes de Relógio no Tecido Adiposo Marrom e sua Análise por Two-away ANOVA

\begin{tabular}{|c|c|c|c|c|c|}
\hline Gene & Genótipo & Circadian Time & DD & LD & ANOVA \\
\hline Per 1 & WT & CT14 (S2) & $9,31 \pm 3,21$ & $28,41 \pm 4,50$ & $\mathrm{p} \leq 0,001$ \\
\hline Per2 & KO & CT14 (S2) & $8,23 \pm 1,58$ & $1,91 \pm 0,85$ & $\mathrm{p} \leq 0,05$ \\
\hline Clock & KO & CT2 (S14) & $0,49 \pm 0,18$ & $5,00 \pm 1,42$ & $\mathrm{p} \leq 0,001$ \\
\hline Bmal1 & KO & CT2 (S14) & $3,28 \pm 0,62$ & $34,62 \pm 7,82$ & $\mathrm{p} \leq 0,001$ \\
\hline
\end{tabular}

\subsection{Expressão dos Canais Trp em Glândula Suprarrenal, Fígado e Tecido}

\section{Adiposo Marrom de Mus musculus}

O próximo passo do trabalho foi avaliarmos a expressão do canal $\operatorname{Trp} V 1$, uma vez que este canal está envolvido na regulação da temperatura corpórea em mamíferos. Dados do nosso laboratório e da literatura (Garami et al., 2011) demonstraram que a temperatura média corpórea de animais $\operatorname{Tr} p V 1 \mathrm{KO}$ é maior e o pico mais duradouro do que em animais WT. Ainda, a análise de outra eferência do relógio central, atividade locomotora, apontou uma menor atividade total em animais $\mathrm{KO}$ para esse canal (Moraes et al., 2015).

Tendo em vista as informações mencionadas, avaliamos inicialmente a expressão de TrpV1 em animais WT em DD e LD. Na glândula suprarrenal, em DD e LD, $\operatorname{Tr} p V 1$ é constitutivo (Figura 24A e B). Ao investigarmos o perfil de expressão deste canal no fígado (Figura 24C e D), observamos que ocorreu um aumento significativo nos trancritos desse gene quando o animal foi submetido a ciclo claroescuro, mostrando um perfil de expressão rítmico, com pico na fase escura (S2); em 
DD, TrpV1 não apresentou diferenças temporais estatisticamente significativas. Assim como no fígado, a expressão de TrpVl no tecido adiposo marrom de animais WT em DD (Figura 24E) não apresentou variação temporal. Em LD, entretanto, é possível identificar uma variação na transcrição entre os tempos, sendo a expressão de $\operatorname{Trp} V 1$ significativamente maior na fase de atividade do que na fase de repouso (Figura 24F).

\section{TrpV1}
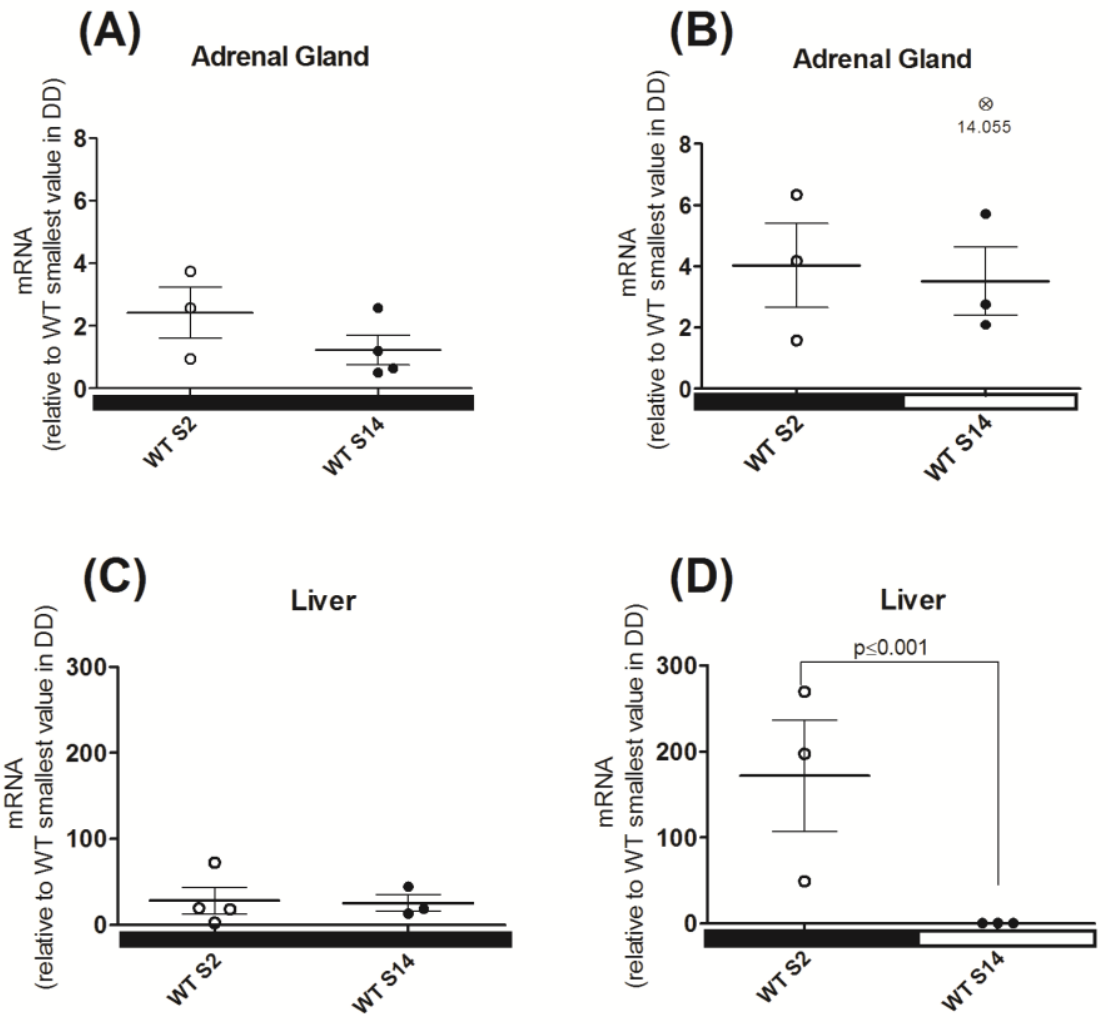

(E)

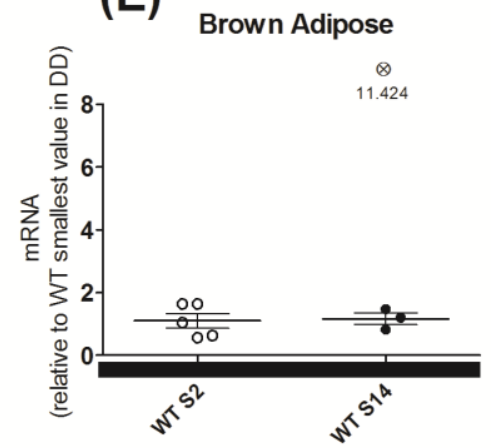

(F)

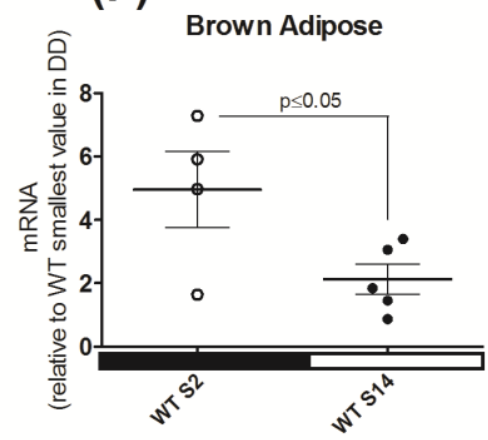

Figura 24. Expressão Gênica de TrpV1 por PCR Quantitativo em Glândula Suprarrenal, 
Fígado e Tecido Adiposo Marrom de Animais WT. (A) Glândula suprarrenal, animais mantidos em escuro constante (DD); (B) Glândula Suprarrenal, animais mantidos em ciclo claro-escuro (12:12 LD). (C) Fígado, animais mantidos em DD; (D) Fígado, animais mantidos em 12:12 LD. (E) Tecido adiposo marrom, animais mantidos em DD; (F) Tecido adiposo marrom, animais mantidos em 12:12 LD. Os valores são apresentados como a média $(n=3-5)$ \pm EPM de expressão de TrpV1 normalizado pelo RNA $18 \mathrm{~S}$ e expressos relativos ao menor valor em DD. Análise estatística utilizada: one-way ANOVA seguida de teste de Tukey. Outlier no valor de 14.055 está indicado em (B) e 11.424 em (E) como círculos cruzados.

Posteriormente, seguimos com a avaliação de um segundo membro da família de termo-TRPs, o canal $\operatorname{TrpA1}$. A principal evidência da literatura que nos encorajou a estudar a dinâmica de transcrição deste canal foi apresentada por Shen e colaboradores (2011), que demonstraram sua participação na termo-resposta de Drosophila em associação com opsinas.

Semelhantemente ao observado para a expressão de $\operatorname{Trp} V 1$, a expressão de TrpA1 na glândula suprarrenal não sofreu nenhuma alteração em resposta ao ciclo claroescuro e, ainda, destacamos que não ocorreu nenhuma variação para este canal, neste tecido, em nenhum dos protocolos analisados (DD e LD) ou entre os genótipos (Figura 25A e B). No fígado de Mus musculus, o gene $\operatorname{TrpAl}$, em escuro constante, mostrou expressão constitutiva, sem alterações ao longo do tempo e sem variação entre genótipos (Figura 25C). Em LD, variações temporais são observadas apenas nos animais nocaute, no entanto, na fase escura encontramos diferenças na expressão desse canal, entre animais WT e TrpV1 KO (Figura 25D). Curiosamente, em animais TrpV1 KO, a transcrição de $\operatorname{Trp} A 1$ encontra-se reduzida na fase escura (S2), o que resulta em um padrão oscilatório desse gene em LD. Dessa forma, inferimos que essa expressão diferencial de $\operatorname{Trp} A 1$ em animais $\operatorname{Trp} V 1$ KO sugere uma compensação de $\operatorname{Trp} A 1$ na 
RESULTADOS

ausência de TrpV1 no fígado de Mus musculus, visto que em animais WT TrpV1 oscilou em LD (Figura 24D) enquanto que $\operatorname{TrpAl}$ exibiu expressão constante nesta condição (Figura 25D). Constatamos a ausência de expressão do canal $\operatorname{Trp} A 1$ em tecido adiposo marrom, em ambos os genótipos, como pode ser observado na Tabela 7.

\section{$\operatorname{TrpA1}$}

(A)

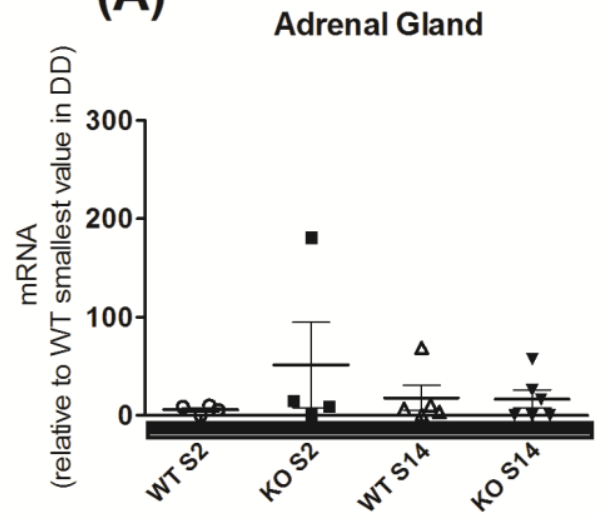

(C)

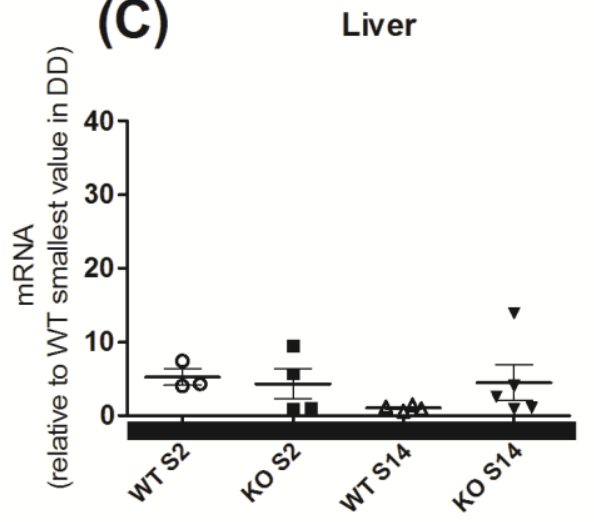

(B)

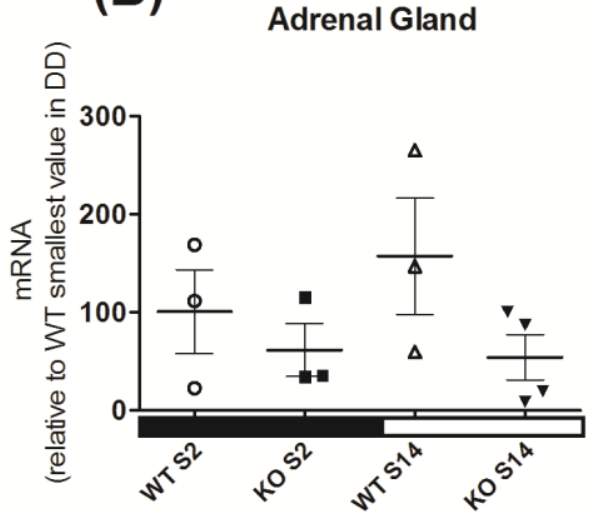

(D)

Liver

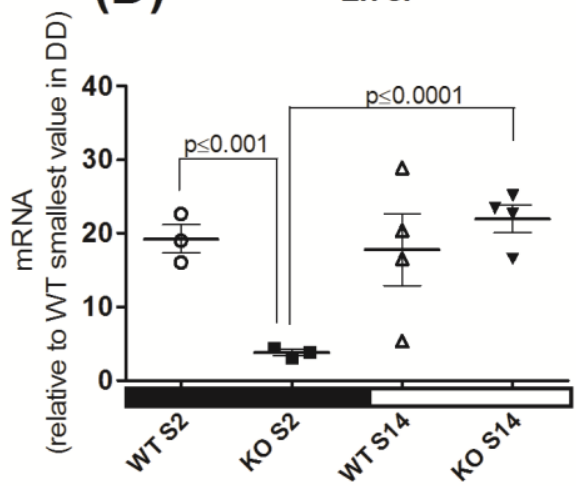

Figura 25. Expressão Gênica de TrpA1 por PCR Quantitativo em Glândula Suprarrenal, Fígado e Tecido Adiposo Marrom de Animais WT. (A) Glândula suprarrenal, animais mantidos em escuro constante (DD); (B) Glândula Suprarrenal, animais mantidos em ciclo claro-escuro (12:12 LD). (C) Fígado, animais mantidos em DD; (D) Fígado, animais mantidos em 12:12 LD. (E) Tecido adiposo marrom, animais mantidos em DD; (F) Tecido adiposo marrom, animais mantidos em 12:12 LD. Os valores são apresentados como a média $(n=3-5)$ \pm EPM de expressão de $\operatorname{Tr} p V 1$ normalizado pelo RNA $18 \mathrm{~S}$ e expressos relativos ao menor valor em DD. Análise estatística utilizada: one-way ANOVA seguida de teste de Tukey. 
Tabela 7. Amplificação em $\mathrm{C}_{\mathrm{T}} \mathrm{s}$ do Canal TrpA1 em Tecido Adiposo Marrom de Mus musculus

\begin{tabular}{|c|c|c|c|c|}
\hline \multirow{4}{*}{ S2 WT } & S2 KO & S14 WT & S14 KO \\
\cline { 2 - 5 } & 34,50 & NA & NA & 39,60 \\
\cline { 2 - 5 } & 33,20 & NA & NA & 38,40 \\
\cline { 2 - 5 } & NA & 39,20 & NA & NA \\
\cline { 2 - 5 } & NA & 36,40 & 39,50 & NA \\
\cline { 2 - 5 } & NA & NA & 31,95 & NA \\
\cline { 2 - 6 } & \multicolumn{4}{|c|}{ LD } \\
\cline { 2 - 5 } & S2 WT & S2 KO & S14 WT & S14 KO \\
\cline { 2 - 6 } & 33,90 & NA & NA & 33,40 \\
\cline { 2 - 6 } & NA & NA & NA & NA \\
\cline { 2 - 6 } & 41,45 & NA & 18,20 & 31,15 \\
\cline { 2 - 6 } & NA & NA & 37,10 & NA \\
\cline { 2 - 6 } & 36,40 & 39,10 & NA & NA \\
\hline
\end{tabular}

Os valores em LD que se mostraram significativamente diferentes daqueles em DD, para os genes dos canais $\operatorname{Trp} V 1$ e $\operatorname{TrpAl}$ na glândula suprarrenal, fígado e tecido adiposo marrom de Mus musculus (two-away ANOVA, seguida do pós-teste Bonferroni, com nível de significância para $\mathrm{p}<0,05)$ encontram-se na Tabela 8 . Destacamos o forte aumento observado no fígado de animais WT, na expressão de TrpV1 e TrpAl durante a fase escura, em resposta ao ciclo claro-escuro. Deve ser destacado aqui que, embora uma oscilação de $\operatorname{Tr} p V 1$ seja observada em LD, tanto no fígado como no tecido adiposo marrom, um aumento da expressão é evidenciado na fase escura em LD quando comparado ao DD (Tabela 8).Valores de TrpA1 neste tecido ainda se mostraram significativamente diferentes na fase clara (S14) de LD, em animais WT e TrpVI KO, com um marcante aumento da expressão desse gene quando comparado aos respectivos genótipos em DD. 
RESULTADOS

Tabela 8. Valores Significativamente Diferentes entre LD e DD Obtidos para Canais Trp na Glândula Suprarrenal, Fígado e Tecido Adiposo Marrom e sua Análise por Two-away ANOVA

\begin{tabular}{|c|c|c|c|c|c|c|}
\hline Tecido & Gene & Genótipo & Circadian Time & DD & LD & ANOVA \\
\hline Fígado & \multirow{2}{*}{$\operatorname{TrpV1}$} & WT & CT14 (S2) & $\begin{array}{c}28,07 \pm \\
15,21\end{array}$ & $\begin{array}{c}172,14 \pm \\
64,84\end{array}$ & $\mathrm{p} \leq 0,05$ \\
\hline $\begin{array}{c}\text { Adiposo } \\
\text { Marrom }\end{array}$ & $\operatorname{TrpV1}$ & WT & CT14 (S2) & $\begin{array}{c}1,10 \pm \\
0,23\end{array}$ & $\begin{array}{c}4,95 \pm \\
1,20\end{array}$ & $\mathrm{p} \leq 0,01$ \\
\hline Fígado & $\operatorname{TrpA1}$ & WT & CT14 (S2) & $\begin{array}{c}5,25 \pm \\
1,11\end{array}$ & $\begin{array}{c}19,22 \pm \\
1,92\end{array}$ & $\mathrm{p} \leq 0,01$ \\
\hline Fígado & $\operatorname{TrpA1}$ & WT & CT2 (S14) & $\begin{array}{c}1,05 \pm \\
0,19\end{array}$ & $\begin{array}{c}17,79 \pm \\
4,87\end{array}$ & $\mathrm{p} \leq 0,001$ \\
\hline Fígado & $\operatorname{TrpA1}$ & KO & CT2 (S14) & $\begin{array}{c}4,49 \pm \\
2,43\end{array}$ & $\begin{array}{c}21,93 \pm \\
1,86\end{array}$ & $\mathrm{p} \leq 0,001$ \\
\hline
\end{tabular}

3.5. Comparação da Expressão dos Genes do Relógio em Glândula Suprarrenal, Fígado e Tecido Adiposo Marrom de Mus musculus

Para compararmos a expressão dos genes estudados entre os tecidos, eliminamos a variável temporal que vinha sendo utilizada nas análises anteriores; sendo assim, temos uma média em 24 horas de dois pontos temporais S2 (sacrifício 2 h após o início das atividades) e S14 (sacrifício 14 h após o início das atividades), que justifica os possíveis altos valores de erro padrão da média, encontrados nos gráficos da Figura 26.

Observamos valores significativos comparando a expressão do gene Perl de animais WT nos três tecidos estudados. Na glândula suprarrenal o gene Perl é amplamente mais expresso do que no fígado e no tecido adiposo marrom em ambas as condições analisadas, DD e LD (Figura 26A e B). Não foram identificadas diferenças na expressão do gene Per2 dos animais mantidos em DD, embora a tendência de maiores valores na glândula suprarrenal tenha se mantido (Figura 26C); em LD, a expressão desse gene na glândula suprarrenal de animais TrpV1 KO se mostrou fortemente maior 
RESULTADOS

do que no fígado e no tecido adiposo marrom (Figura 26D). A expressão do gene Clock em animais $\mathrm{KO}$ mantidos em DD se mostrou significativamente maior na glândula suprarrenal do que no fígado (Figura 26E); em LD nenhuma diferença de expressão desse gene entre os tecidos analisados foi constatada (Figura 26F). O gene Bmall, por sua vez, não apresentou diferenças em sua expressão em DD nos diferentes tecidos, tanto para animais WT quanto para TrpV1 KO (Figura 26G); todavia, em LD, assim como observado para o gene Perl, o gene Bmall se mostrou mais expresso na glândula suprarrenal do que no fígado e no tecido adiposo marrom de animais WT (Figura 26H). 
RESULTADOS

Per1
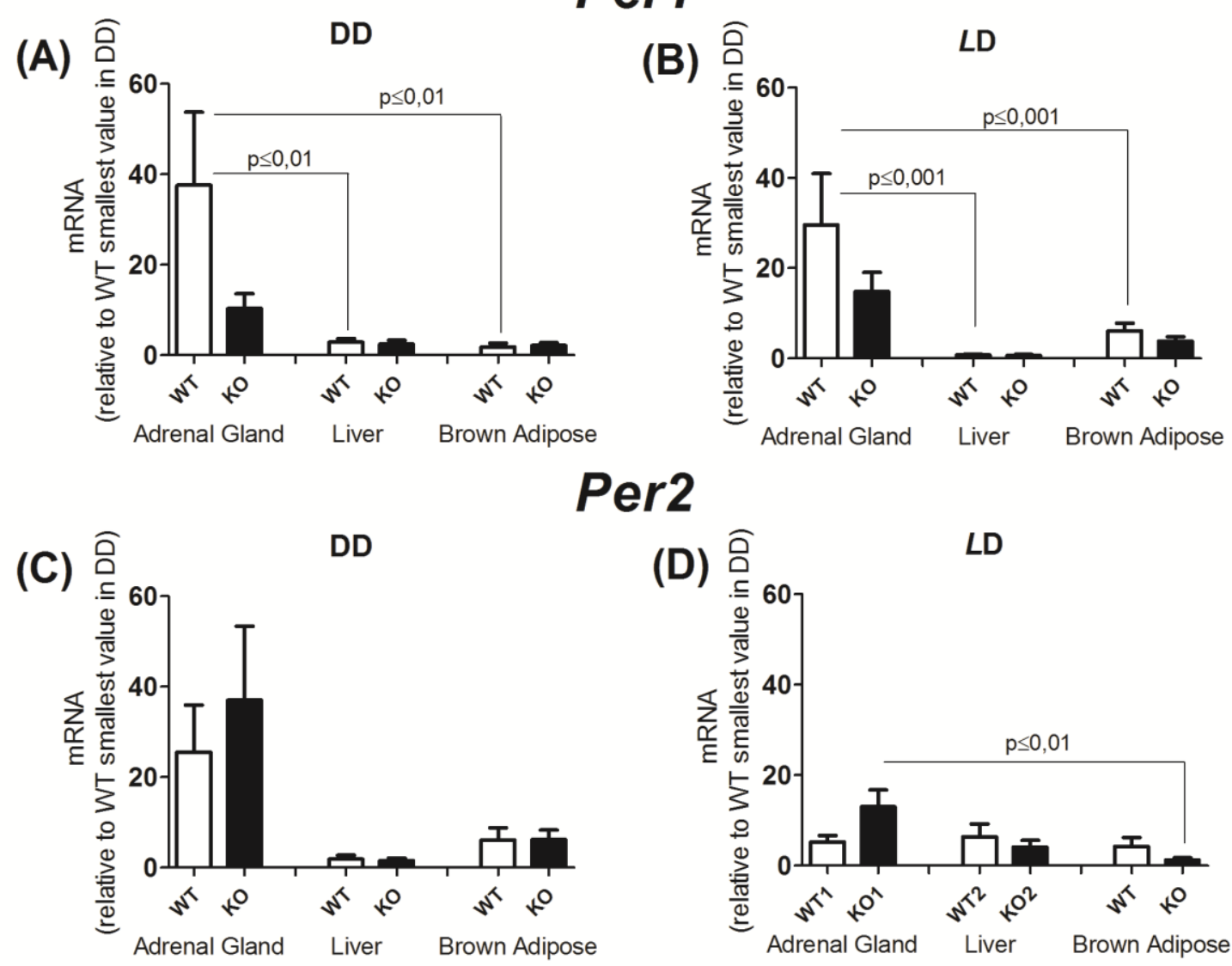

(D)

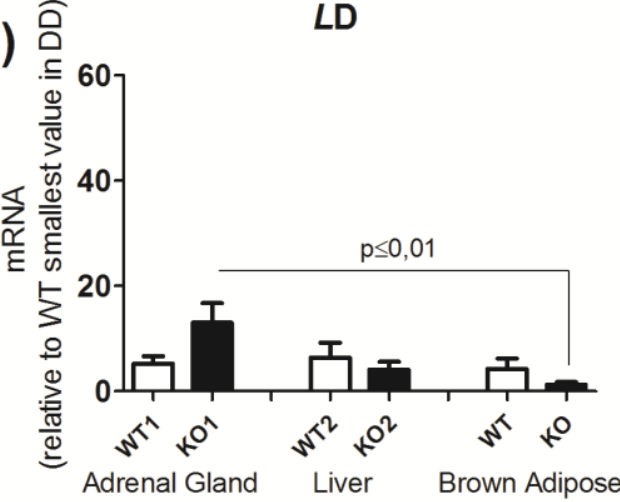

\section{Clock}

(E)

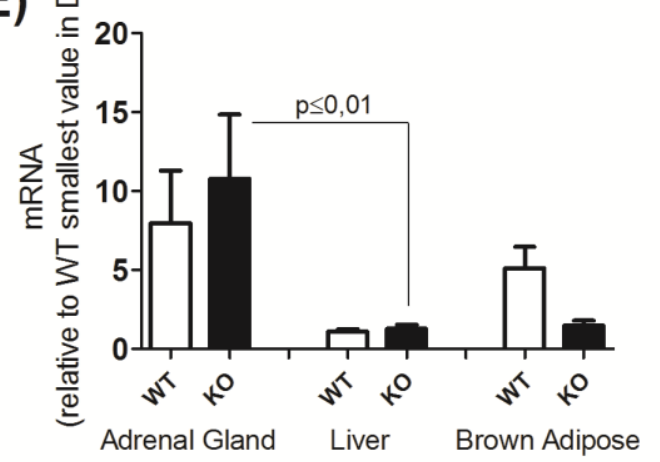

(F)

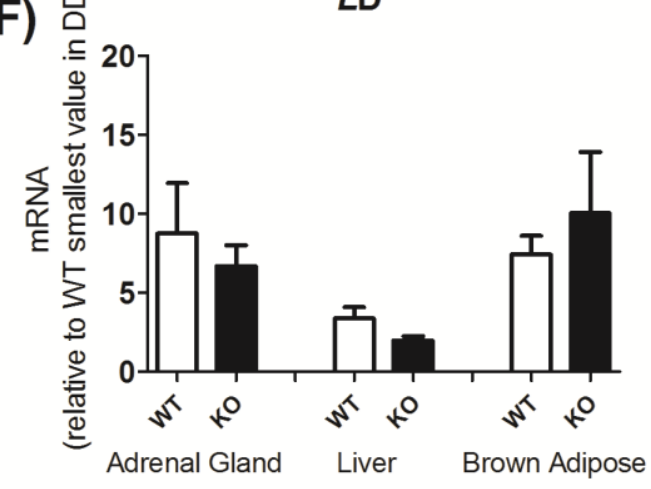

\section{Bmal1}
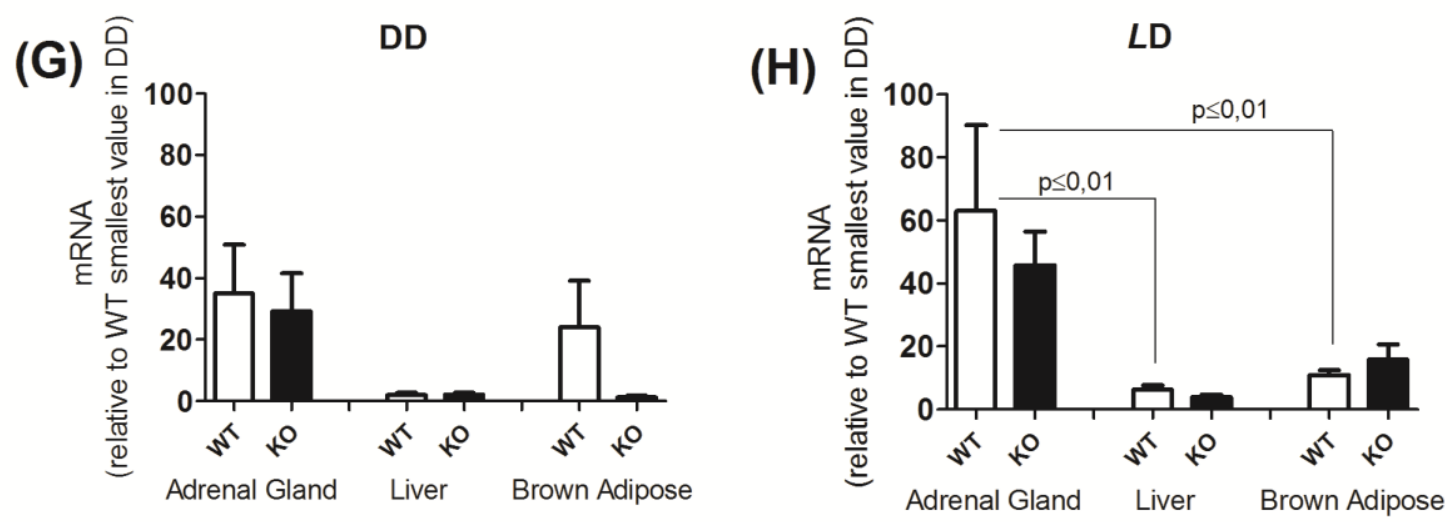
Figura 26. Expressão dos Genes do Relógio por PCR Quantitativo em Glândula Suprarrenal, Fígado e Tecido Adiposo Marrom de Animais WT. (A) Perl, animais mantidos em escuro constante (DD); (B) Perl, animais mantidos em ciclo claro-escuro (12:12 LD). (C) Per2, animais mantidos em DD; (D) Per2, animais mantidos em 12:12 LD. (E) Clock, animais mantidos em DD; (F) Clock, animais mantidos em 12:12 LD. (G) Bmall, animais mantidos em DD; (H) Bmall, animais mantidos em 12:12 LD. Os valores são apresentados como a média $(\mathrm{n}=6-10) \pm$ EPM de expressão de Per1, Per2, Clock e Bmal1 normalizados pelo RNA $18 \mathrm{~S}$ e expressos relativos ao menor valor em DD de cada gene. Análise estatística utilizada: one-way ANOVA seguida de teste de Tukey.

\subsection{Expressão dos Genes do Relógio e Canais Trp em Glândula}

\section{Suprarrenal de Mus musculus Mantidos em Luz Constante}

Observamos em luz constante (LL) uma ampla variação dos $\mathrm{C}_{\mathrm{T}} \mathrm{s}$ para todos os genes analisados. É sabido que as rápidas mudanças no ciclo do sono ou outros efeitos causados durante um jetlag ou shift work, por exemplo, levam a um desalinhamento de relógios circadianos internos. De fato, quando se analisou a expressão dos genes de relógio em glândula suprarrenal de animais em LL, os dados foram completamente inconsistentes, até mesmo para o house-keeping gene, RNA 18S (Tabela 9). Uma vez que estes resultados foram inconclusivos possivelmente devido a alta intensidade de luz à qual os animais foram expostos, não realizamos a análise dos genes do relógio nessa condição para os demais tecidos.

Tabela 9. Amplificação em CTs dos Genes de Relógio em Glândula Suprarrenal de Mus musculus Submetidos a Luz Constante (LL)

\begin{tabular}{|c|c|c|c|c|c|c|c|c|}
\hline \multicolumn{10}{|c|}{ Amplificação em animais submetidos a LL $\left(\mathbf{C}_{\mathbf{T}} \mathbf{S}\right)$} \\
\hline Genes & \multicolumn{2}{|c|}{ WT S2 } & \multicolumn{2}{c|}{ WT S14 } & \multicolumn{2}{c|}{ KO S2 } & \multicolumn{2}{c|}{ KO S14 } \\
\hline Per1 & 27.17 & 24.99 & 40.09 & 32.25 & NA & 25 & 40.02 & 43.32 \\
\hline Per2 & NA & 40.7 & 25.11 & 35.3 & 30.52 & 31.77 & 23.24 & 23.92 \\
\hline Clock & 33.9 & 33 & 25.99 & 38.27 & 34.11 & 28.46 & 24.52 & 24.36 \\
\hline Bmal1 & 28.2 & 25.84 & 38.12 & 38.09 & 39.96 & 26.04 & 36.98 & 31.29 \\
\hline TrpV1 & 31.75 & 28.75 & NA & NA & NA & NA & NA & NA \\
\hline TrpA1 & 32.75 & 32.05 & NA & NA & 34.70 & 30.75 & NA & NA \\
\hline 18S & 12.20 & 10.65 & 29 & 28.75 & 28.9 & 9.5 & 28.2 & 21.9 \\
\hline
\end{tabular}




\section{Discussão}

"Descobrir consiste em olhar para o que todo mundo está vendo e pensar uma coisa diferente".

Roger Von Oech 
Em mamíferos, a melanopsina presente na retina é responsável por detectar a presença da luz e promover a sincronização do relógio central no NSQ (Berson et al., 2002). O arrastamento fótico do NSQ aos ciclos claro-escuro leva a informação de luz aos relógios periféricos, que são insensíveis a luz e, portanto, dependentes de vias humorais ou neurais para serem sincronizados (Mohawk et al., 2012). Todavia, em vertebrados não-mamíferos, essa via de informação fótica pode atuar de forma direta sobre os relógios periféricos. Estudos em linhagens celulares fotossensíveis de Danio rerio (zebrafish) revelaram que estímulos luminosos são capazes de regular a transcrição de genes de relógio, tanto sincronizando aqueles arrítmicos como alterando a fase dos que oscilam (Vallone et al., 2004; Carr e Whitmore, 2005; Tamai et al., 2005; Carr et al., 2006), demonstrando a independência dos osciladores periféricos nesse grupo.

Um interessante estudo realizado em 2011 por Shen e colaboradores demonstrou a interação de ciclos de luz e temperatura: a detecção de temperatura mediada por canais TRP em Drosophila é dependente de rodopsina. Animais mutantes sem rodopsina, mantidos em escuro constante, perderam a capacidade de discriminar a temperatura, sendo que a termossensibilidade foi restaurada pela transfecção do fotopigmento melanopsina que, como citado anteriormente, participa diretamente da percepção de luz e sincronização do relógio central em mamíferos.

Considerando estas duas importantes constatações, percepção de luz exclusiva pela retina e percepção de temperatura aliada a opsinas, identificamos a linhagem de células B16-F10 Per1::Luc como um modelo promissor para o estudo de luz e temperatura em relógios periféricos. As células B16-F10 sabidamente expressam rodopsina (Lopes et al., 2010) e, recentemente, identificamos em nosso laboratório a expressão do RNAm e da proteína para melanopsina (Moraes et al., 2015) 
Nossos experimentos demonstraram que um pulso de luz azul, com intensidade de 650 lux, não interfere na expressão gênica de Perl em células B16-F10 Perl::Luc. Dados de PCR quantitativo de nosso laboratório demonstraram que um pulso de luz branca (650 lux) por 15 min também não foi capaz de sincronizar a expressão dos genes Perl, Clock, Bmall e Cryl em células B16-F10 e em células Melan-A; entretanto, parece haver um aumento da transcrição de Perl 30 h após o pulso de luz branca em células B16-F10 (Assis et al., 2015). Esses dados corroboram nossos resultados mostrados aqui, uma vez que nesse modelo a luz não atua como uma importante pista para sincronização da maquinaria, mas pode atuar na promoção de outros eventos fisiológicos, como a regulação da produção de melanina. Recentemente foi demonstrada uma rápida produção de melanina em células em cultura da pele de humanos em resposta a radiação UVA, com provável participação da rodopsina (Whicks et al., 2011; Bellono et al., 2013).

Nossos dados com temperatura, por sua vez, demonstraram que um pulso de 39, $5^{\circ} \mathrm{C}$ foi capaz de promover a sincronização dessas células em DD, imprimindo um ritmo circadiano que não foi observado no controle. Células, quando colocadas em cultura, perdem o acoplamento umas com as outras e por isso apresentam-se em livre curso na ausência de uma pista sincronizadora. Observamos claramente por meio do registro da bioluminescência que, em condições constantes, a expressão de Perl encontra-se arrítmica, uma vez que em cada placa de cultura foi observado um período diferente. Dessa forma, o pulso de temperatura propiciou que as células em cada placa entrassem em fase umas com as outras, e com as populações celulares das outras placas, e assim as culturas de todas as placas passassem a apresentar um período dentro da faixa do circadiano, o que não foi observado após o estimulo fótico.

Em homeotermos, as respostas são espécie-específicas e apresentam grande variabilidade individual. Mamíferos não ajustam sua temperatura corporal a ciclos de 
temperatura ambiente, uma vez que eles possuem um sistema de compensação de temperatura, onde termo-receptores presentes em órgãos internos, na pele e no cérebro, garantem o ajuste da temperatura interna. Através de sinais enviados pelos termoreceptores para centros de termorregulação, localizados na área pré-optica do hipotálamo anterior, mecanismos de feedback promovem perda de calor e/ou a produção de calor, resultando em pequenas variações da temperatura (Romanovsky 2007), mantendo a temperatura corporal desses animais sempre ajustada. Contudo, experimentos in vitro mostraram que, ao contrário do que é visto em relógios centrais, ciclos de temperatura externa podem manter o ritmo de expressão de genes de relógio em tecidos periféricos. Fibroblastos Rat-1 (Brown et al., 2002) e células de glia em cultura (Prolo et al., 2005) ajustam a expressão rítmica de genes de relógio em resposta a ciclos de temperatura externa. Saini e colaboradores (2012) também observaram que, em fibroblastos de ratos, flutuações diárias de temperatura foram capazes de sincronizar a expressão do gene Per2. De fato, Buhr e colaboradores (2010) deram pulsos de $2,5^{\circ} \mathrm{C}$ em órgãos como hipófise e pulmão de camundongo e provaram que a resistência ao arrastamento por temperatura é uma característica somente do relógio central de mamíferos, o NSQ, mas não de osciladores periféricos. Como mencionado anteriormente, essa propriedade garante que o NSQ desencadeie ritmos diários de temperatura corporal (sem que seja afetado por temperatura ambiente) que, então, atuam como pistas para ajustar o ritmo do relógio periférico existente em cada célula do organismo, intensificando a sincronização circadiana (Edery, 2010). Contudo, vale mencionar, que existe um relato de mudança de fase em curvas de fase/resposta de neurônios do NSQ de ratos, in vitro, submetidos a pulsos de temperatura (Ruby et al., 1999).

Os sensores moleculares que participam na percepção das variações térmicas para regular a atividade circadiana ainda são um enigma (Lee e Montell, 2013). 
Contudo, mesmo que ainda não saibamos a via que leva a informação de temperatura para os relógios periféricos de mamíferos, nossos experimentos com a linhagem transgênica B16-F10 de Mus musculus nos permitem inferir que de alguma forma a temperatura é capaz de promover a sincronização celular.

Embora o ritmo circadiano seja gerado pelo NSQ em mamíferos (Lehman et al., 1987), as proteínas de relógio são amplamente expressas por todo o corpo (Abraham et al., 2006). Em diversos órgãos, como coração, pulmão, rim, músculo esquelético, glândula suprarrenal, pele e fígado, sua expressão ocorre de forma circadiana (Sakamoto et al., 1998; Zylka et al., 1998; Yamazaki et al., 2000; Stokkan et al., 2001). Além disso, a expressão de genes de relógio tem sido demonstrada também em células em cultura (Balsalobre et al., 1998; Whitmore et al., 2000), isso porque cada célula individual possui maquinaria molecular funcional. No entanto, o NSQ é fundamental para organização desses ritmos, bem como para estabelecer a mesma fase entre os vários relógios periféricos (Kornmann et al., 2007). Luz e temperatura são as duas pistas temporais mais relevantes para resetar o relógio endógeno, ainda que, relativamente, pouco se saiba sobre a regulação circadiana por temperatura (Ki et al., 2015), aparentemente, esses dois zeitgebers trabalham juntos para manter os ritmos circadianos (Yoshii et al., 2009). Nos mamíferos, alterações de temperatura provocam ações termorregulatórias que podem influenciar até no comportamento do animal, e uma falha na termorregulação pode causar uma desorganização interna levando a prejuízos a saúde do indivíduo (Bouchama e Knochel, 2002; Brown et al., 2012). Logo, embora a temperatura externa seja um sinal fraco para sincronizar os relógios periféricos (Saini et al., 2012), a temperatura interna atua como um importante agente sincronizador nesses relógios (Buhr et al., 2010), concordando com os nossos resultados demonstrados em células transgênicas B16-F10. 
Com base nessas informações, hipotetizamos que a informação de luz percebida via melanopsina na retina, levaria à regulação da temperatura circadiana pelo NSQ, e a temperatura corporal, por sua vez, poderia atuar como uma pista interna para a sincronização dos tecidos periféricos.

Dados obtidos pelo nosso laboratório apontam para a importante participação do canal TRPV1 no controle da temperatura corporal (Moraes et al., 2015), assim como indicam diversos outros estudos (Caterina et al., 2000; Caterina, 2007; Gavva et al., 2008; Mills et al., 2008). Em nossos experimentos, animais WT e TrpV1 KO tiveram sua temperatura corporal média monitorada durante o período de atividade: observou-se que os animais que não expressavam esse canal mantinham por mais tempo as altas temperaturas, que por vezes, podem ser nocivas a eles. Adicionalmente também foi observado que animais TrpVl KO apresentaram uma diminuição da atividade locomotora. Garami e seus colaboradores (2011), usando camundongos WT e TrpVI $\mathrm{KO}$, fizeram a mesma constatação em relação ao aumento da temperatura corporal em animais nocaute para TrpV1. Entretanto, no que se refere a atividade locomotora, contrário aos nossos resultados, eles observaram um aumento da mesma em animais TrpV1 KO. Por outro lado, em aparente contradição com seus próprios resultados, eles constataram uma diminuição significativa na atividade locomotora usando um antagonista para TRPV1 em animais WT. Existem, ainda, trabalhos que mostram que a ausência de TrpVl não acarreta mudanças na atividade locomotora (Caterina et al., 2000; Davis et al., 2000; Marsch et al., 2007). Contudo, uma vez que a atividade locomotora aumenta a temperatura corporal e na ausência de $\operatorname{Trp} V 1$ tenhamos uma maior exposição as altas temperaturas, nos parece uma alternativa razoável a diminuição da atividade, para que assim, se diminuam também, os efeitos desastrosos das altas temperaturas ao metabolismo. 
Verificamos, também, em alguns tecidos periféricos, se a expressão dos genes do relógio seria afetada pela ausência do canal TRPV1, acordando com a nossa hipótese citada anteriormente, de que o controle da temperatura corporal atuaria como uma eferência do relógio central aos periféricos. Com isso, observamos que na glândula suprarrenal de animais mantidos em DD, Perl, Per2, Clock e Bmall aparentam ser constitutivos. Já, sob influência da alternância claro-escuro, a expressão do gene Per2 apresentou-se aumentada em animais $\operatorname{Trp} V l \mathrm{KO}$ no início da fase de atividade quando comparada temporalmente com a expressão na fase clara, estabelecendo um padrão oscilatório. Horta (2015) constatou que, na suprarrenal de ratos, a dessensibilização do TRPV1 aboliu o perfil rítmico de expressão de Perl e Bmall, e o bloqueio do canal aumentou a expressão de Perl neste tecido. Entretanto a análise por PCR quantitativo foi realizada 1 hora após o tratamento com o antagonista, sendo esse um tratamento agudo, enquanto que em animais nocautes, a ausência do canal é crônica, podendo levar a compensações durante o desenvolvimento. Adicionalmente, injeção de antagonistas in vivo não garante a supressão total do canal, em contraposição ao seu nocaute. Embora nossos resultados não apresentem um perfil rítmico para os genes do relógio na suprarrenal, essa glândula tem sido considerada um típico oscilador periférico, uma vez que projeções do NSQ alcançam-na e submetem seu funcionamento a um padrão circadiano. Em adição, a suprarrenal também abriga componentes moleculares da maquinaria do relógio biológico, o que poderia levar a crer que a regulação da atividade de biossíntese dos corticoides bem como a regulação da sensibilidade a estímulos humorais, como por exemplo, o ACTH, estariam sob controle do relógio intrínseco à glândula (Oster et al., 2006; Dickmeis, 2009). Em condições constantes, Oster e colaboradores (2006) detectaram que, na suprarrenal de camundongos, mais de 1500 genes são ritmicamente expressos, sendo que os genes de relógio Bmall, Per2, Per3 e Cryl e os genes controlados pelo relógio, Rev-erba, $D b p$ e Tef, apresentam uma 
oscilação fortemente demarcada, de grande amplitude. Acreditamos que a ausência de ritmo na expressão dos genes estudados em nosso trabalho se justifique por terem sido analisados apenas dois pontos temporais, de forma que, caso haja realmente uma oscilação, o aumento ou diminuição significativo da expressão esteja em outros pontos não analisados. Zhang e colegas (2014), ao classificarem a robustez da expressão de genes de relógio em órgãos considerados importantes relógios periféricos, apontaram que a suprarrenal apresenta a mais baixa amplitude de oscilação dos genes circadianos quando comparada ao fígado, rim, pulmões, tecido adiposo marrom e coração. O fígado foi identificado, neste estudo, como o tecido que apresenta a maior quantidade de genes com padrões rítmicos de transcrição: foram identificados 3186 genes circadianos no fígado, os quais representam 16\% de todos os 19788 genes analisados, enquanto que para a suprarrenal esse percentual é de somente 5\% (Zhang et al., 2014).

Em nossos resultados, observamos no fígado um perfil oscilatório na expressão de quase todos os genes estudados; a exceção foi o gene Clock que se apresentou constitutivo. Perl apresentou variação apenas em DD, onde se verificou, temporalmente, uma diminuição significativa de sua expressão na fase clara subjetiva; também é possível afirmar que, em ciclo claro-escuro, a expressão de Perl em animais WT está diminuída durante a fase escura. No estudo de Sakamoto e colaboradores (1998), a análise por Northern blot demostrou que, em ratos mantidos em LD (12:12), Per2 tem expressão rítmica no fígado, sendo o pico na fase escura, semelhantemente aos nossos resultados com camundongos. Tanto animais WT quanto TrpV1 KO apresentaram diferenças significativas na expressão desse gene em comparação temporal (S2 e S14). O gene Bmal1 apresentou um perfil rítmico tanto em DD quanto em LD, de modo que sua expressão aumentou significativamente na fase de repouso, em ambos os genótipos (WT e TrpV1 KO), além de apresentar uma diferença significativa em seus transcritos, entre animais WT e TrpV1 KO, na fase clara (S14). 
Após a dessensibilização do canal com agonista do canal TRPV1, Horta (2015) revelou que, no fígado de rato, o perfil rítmico da expressão de Perl é abolido e o perfil de Bmall se mantém, embora com um valor de pico aumentado. Já o bloqueio do canal com o antagonista AMG-517 não alterou a expressão de Perl e aumentou os níveis de Bmall. Mais uma vez, nossos resultados diferem parcialmente daqueles de Horta, ressaltando a diferença entre os dois modelos - bloqueio de TRPV1 ou sua remoção por nocaute. Entre os relógios periféricos, o controle da maquinaria no fígado é um dos mais importantes, visto que este órgão desempenha um papel central no metabolismo e na produção de energia, afetando de forma significativa o estado fisiológico do organismo inteiro (Ribas-Latre et al., 2015). Por exemplo, o fígado é o principal local de metabolismo intermediário, incluindo a síntese e degradação de colesterol (Edwards et al., 1972), bem como a regulação da homeostase da glicose (Lamia et al., 2008). De fato, $10 \%$ de todas as transcrições e $20 \%$ de todas as proteínas deste tecido estão sob regulação do sistema circadiano (Reddy et al., 2006), ressaltando a importância da maquinaria presente neste órgão. Além disso, o fígado pode ter seu relógio facilmente controlado pelo ritmo de ingestão de alimento (Damiola et al., 2000), chegando até a se desacoplar do NSQ (Landgraf et al., 2015).

Analisando o tecido adiposo marrom, nossos resultados demonstraram que todos os genes que analisamos são ritimicamente expressos; de fato, Zhang e colaboradores (2014) identificaram no tecido adiposo marrom de camundongo, 1400 genes expressos circadianamente, cerca de $8 \%$ de todos os genes analisados. Nossa análise se iniciou com a UCP1, uma molécula chave na termogênese do tecido adiposo marrom (Yoneshiro e Saito, 2013), cujo gene apresentou expressão constitutiva em DD e oscilações ritmicas quando em LD. Identificamos que, em animais nocaute, ocorre uma diminuição significativa da transcrição no ínicio do período de atividade, gerando diferenças tanto entre genótipos (animais WT na mesma fase), como temporalmente 
(animais nocaute na fase de repouso). Semelhantemente aos nossos resultados através de qPCR para o tecido adiposo marrom, Yamashita e colegas (2008) verificaram por Northern Blot, em ratos mantidos em LD, que na presença de antagonista para o TRPV1 a expressão de Ucpl diminui significativamente. E, ainda, também em concordância com nossos achados, Iwasaki e colaboradores (2011) identificaram por Western Blot que, em camundongos mantidos em LD, a fração de UCP1 mitocondrial presente no tecido de animais WT não apresenta variações. Dessa forma, inferimos que, de alguma maneira, a ausência do canal TrpVI altera a expressão desse gene, possívelmente afetando a termogênese nesse tecido. Vale lembrar que a temperatura corporal nos animais nocautes está aumentada e, uma vez que temos o canal TRPV1 como sensor de altas temperaturas, variável importante para o metabolismo do tecido adiposo marrom, acreditamos que a ausência do canal impede a correta expressão da maquinaria envolvida na termogênese, afetando a expressão de Ucp1. Estudos também apontam o envolvimento do canal TRPM8, além do TRPV1 (Yoneshiro e Saito, 2013), na termogênese deste tecido (Ma et al., 2012); contudo, o TRPM8 é responsável por perceber baixas temperaturas, o que nos permite hipotetizar que, para o bom funcionamento da maquinaria loca, é necessária a integridade destes dois canais. Nossos resultados com os genes Perl e Per2 corroboram a hipótese de falha na maquinaria em animais nocaute, já que estes genes apresentam variações diferentes dos animais WT, levantando a possibilidade de que Ucpl esteja atuando como um CCG, uma vez que sua expressão parece depender do correto funcionamento da maquinaria do relógio.

Ainda no tecido adiposo marrom, chama atenção o aumento na produção de RNAm de Perl em animais WT, durante a fase escura em ciclo claro-escuro, passandose a observar uma oscilação temporal nesses animais mantidos em LD e uma diferença significativa entre animais WT e $\operatorname{Tr} p V 1 \mathrm{KO}$ durante a fase de atividade, o que não era observado em DD. O gene Per2 apresentou variações em seus transcritos para animais 
WT quando submetidos à LD, além de uma drástica redução de expressão em S2, induzida pelo ciclo claro-escuro, nos animais $\operatorname{Trp} V 1 \mathrm{KO}$. Na expressão do gene Clock, observa-se uma oscilação ritmica apenas em animais TrpVl KO em LD, provavelmente, resultado da alta expressão na fase clara provocada pelo ciclo claro-escuro. O gene Bmall é expresso com variações significativas, em DD para animais WT e em LD na ausência do canal TrpVI; em DD também é observada um diferença entre sua expressão em animais WT e nocaute durante a fase de claro subjetivo. Em 2006, Zvonic e colegas demonstraram a robusta expressão rítmica dos genes Npas-2 (análogo do gene Clock), Bmall, Per1, Per3, Cryl e Cry2 em tecido adiposo marrom de camundongos mantidos em LD (12:12), semelhantemente a nossos resultados em animais WT. Os autores afirmam que a presença de um relógio circadiano ativo em depósitos de gordura sugere a existência de um elemento temporal para a regulação do tecido adiposo marrom. Outros estudos identificaram que a disfunção dessa maquinaria leva à obesidade e a síndromes metabólicas (Rudic et al., 2004; Turek et al., 2005), demonstrando a importância do controle da maquinaria do relógio neste tecido.

Apesar da variação encontrada em nossos resultados entre indíviduos, podemos ainda afirmar que a suprarrenal, fígado e tecido adiposo marrom possuem uma maquinaria do relógio tipicamente ativa, e acreditamos que a oscilação dos genes de relógio observada nesses tecidos é expressiva, sugerindo que a presença do canal TRPV1 pode ser essencial, variando de acordo com o tecido.

Gavva e colaboradores (2008) demonstraram, tanto em humanos quanto em ratos, que o bloqueio de TRPV1 leva à hipertermia. Szikszay e colaboradores (1982) já destacavam o envolvimento da capsaicina, agonista dos canais TRPV1, no controle da temperatura interna, demonstrando que sua infusão induzia uma hipotermia seguida de um período de hipertermia. Mais recentemente, Mills e colaboradores (2008) 
observaram que a dessensibilização dos canais TRPV1 fazia com que os animais perdessem sua capacidade de regular a temperatura interna durante o aquecimento.

Com isso, avaliando a expressão deste canal nos tecidos estudados neste trabalho, observamos que, na glândula suprarrenal, TrpV1 não apresentou oscilação rítmica em sua expressão. Na literatura, praticamente nenhuma informação é encontrada relacionando a expressão de $\operatorname{TrpVI}$ em suprarrenal; contudo, Horta (2015) também verificou a expressão deste canal em suprarrenal de ratos e, corroborando nossos resultados, não encontrou variação em sua expressão ao longo do tempo. No fígado, a expressão de $\operatorname{Trp} V 1$ já foi demonstrada em diversas espécies (Vennekens et al., 2008), sendo que, em ratos, ele apresenta uma oscilação rítmica temporal (Horta, 2015). Assim como o observado em nossos resultados em fígado de camundongo em LD, que mostraram a ocorrência de um aumento significativo nos trancritos desse canal, revelando um perfil de expressão rítmica, com pico na fase de atividade. Existem vários estudos que relacionam a variação na expressão do $\operatorname{Trp} V 1$ no tecido adiposo marrom, por exemplo, à obesidade, à resistência a insulina e a leptina (Lee et al., 2015), à termogênese (Yoneshiro e Saito, 2013), à adipogênese (Vennekens et al., 2008), entre outras. Nossos dados demonstraram que, embora sua expressão não seja muito alta, esse canal é expresso de maneira rítmica em tecido adiposo marrom de camundongos mantidos em LD. Nos três tecidos analisados, TrpV1 parece ser constitutivo em DD. Interessantemente, vemos que o $\operatorname{Tr} p V 1$, além de ser expresso na glândula suprarrenal, fígado e tecido adiposo marrom, apresenta uma transcrição rítmica em animais em LD, corroborando nossa hipótese de que canais TRP atuam como mediadores da informação de luz que chega ao NSQ e é transmitida aos tecidos periféricos, para sincronizá-los. Outro estudo que reforça essa interação é o de Bellono e colaboradores (2013), onde eles demonstraram que melanócitos humanos expostos a UVA respondem com uma produção rápida de melanina envolvendo um receptor acoplado a proteína $\mathrm{G}$ dependente 
de retinal, e que leva à ativação do canal TRPA1. Interessantemente, esta via de fototransdução é muito similar à via da melanopsina na retina (Hankis et al., 2008), demonstrando a convergência das vias de sinalização para canais TRP e sua relação com relógios circadianos.

Baseados nesses dados, aliados à informação de que TRPA1 participa do controle de temperatura em Drosophila (Shen et al., 2011) e que pode formar um heterodímero com o canal TRPV1 originando um terceiro canal, TRPA1V1 (Sadofsky et al., 2014), analisamos a expressão de $\operatorname{TrpA} 1$ em glândula suprarrenal, fígado e tecido adiposo marrom de camundongos WT e TrpVI KO. Curiosamente, descobrimos que TrpA1 não é expresso em tecido adiposo marrom de camundongo, embora a literatura relate a expressão deste canal em tecido adiposo marrom de ratos (Yamashita et al., 2008) e de camundongos, só que nestes com valores de $C_{T}$ do gene maiores que 32 (Bishnoi et al., 2013), o que para muitos pesquisadores é considerado como não expressão do gene. Na glândula suprarrenal, embora expresso, este canal não apresentou variação temporal em sua expressão, seja em DD ou LD, em animais WT ou TrpV1 KO. No fígado, nenhuma diferença significativa foi observada na expressão de $\operatorname{Trp} A 1$ em DD para ambos os genótipos; já em LD os animais TrpV1 KO apresentaram um grande aumento da transcrição de $\operatorname{Trp} A 1$ na fase de repouso quando comparada à fase de atividade, além de uma variação significativa de sua expressão entre animais WT e nocaute na fase de repouso. Essa expressão diferencial do $\operatorname{TrpAl}$ em animais nocaute poderia indicar uma dinâmica de compensação do canal TRPA1 na ausência de TRPV1. Chen (2015) afirma que o canal TRPA1 tem a capacidade de ganho ou perda de sensibilidade térmica de acordo com o acoplamento com outros canais TRP, como o TRPV1 e o TRPM8. De fato, Sadofsky e colaboradores (2014) propõem que essa coexpressão de TRPA1 e TRPV1 na mesma célula pode alterar completamente a resposta 
destes canais, chegando até a modificar o perfil de ação de agonista para antagonista e vice-versa.

Surpreendentemente, nossos resultados em animais submetidos à luz constante se mostraram completamente inconsistentes, até mesmo para o house-keeping gene, RNA 18S. Todavia, sabe-se que as rápidas mudanças no ciclo do sono ou outros efeitos causados durante um jetlag ou shift work, por exemplo, levam a um desalinhamento de relógios circadianos internos. E, acredita-se que os glicocorticoides, hormônios produzidos na glândula suprarrenal, estejam envolvidos com a adaptação do sistema circadiano frente a estas condições adversas sob o ponto de vista cronobiológico (Leliaviski et al., 2014). Desta maneira, podemos inferir que possivelmente o estresse causado pela luz constante, por causar a arritmia no relógio central, levou a total desequilíbrio da transcrição e consequentemente tradução de, não só genes de relógio, mas inúmeros outros genes do animal.

Considerando os achados discutidos neste trabalho sobre o envolvimento dos canais TRP em resposta à luz e temperatura, acreditamos ter fortalecido nossa hipótese inicial da participação direta desses canais, sobretudo TRPV1, na mediação da sincronização dos tecidos periféricos via relógio central, principalmente após demonstrarmos que tecidos periféricos são sincronizados por alterações de temperatura e, assim, destacado a importância de mais estudos que elucidem detalhadamente este envolvimento. 


\section{Conclusões}

"A persistência é o menor caminho para o êxito."

Charles Chaplin 
Os dados apresentados nesse trabalho nos permitem concluir que as células B16F10 Per1::Luc, tecido periférico de mamífero, possuem a capacidade de ajustarem a expressão do gene Perl por meio de um pulso de temperatura com duração de $1 \mathrm{~h}$ e $2,5^{\circ} \mathrm{C}$ acima da temperatura de manutenção.

Acreditamos ter fortalecido nossa hipótese de que a luz sinaliza aos tecidos periféricos através de uma via indireta, onde canais TRP atuam como mediadores da informação de luz que chega ao NSQ e é transmitida aos tecidos periféricos, para sincronizá-los, uma vez que demonstramos o envolvimento do canal $\operatorname{Trp} V 1$ na expressão dos genes do relógio Perl, Per2, Clock e Bmall em glândula suprarrenal, fígado e tecido adiposo marrom de camundongos submetidos in vivo a diferentes protocolos de iluminação. Verificamos também que o gene Perl é mais expresso em suprarrenal do que em fígado e tecido adiposo marrom de Mus musculus.

Destacamos a expressão diferencial do $\operatorname{TrpAl}$ em fígado de animais $\operatorname{Tr} p V l \mathrm{KO}$, indicando existir uma dinâmica de compensação do canal TRPA1 na ausência de TRPV1; bem como a expressão diferencial de Ucpl, também em animais nocaute, sugerindo uma falha na maquinaria local do tecido adiposo marrom na ausência do canal.

De modo geral, nossos achados contribuem de forma significativa para o entendimento da sincronização de tecidos periféricos de mamíferos, por luz e temperatura. 


\section{Bibliografia}

"A sabedoria dos homens é proporcional não à sua experiência mas à sua capacidade de adquirir experiência."

George Bernard Shaw 
Abe M, Herzog ED. Circadian rhythms in isolated brain regions. J. Neurosci. 22(1): 350-356, 2002.

Abraham D, Dallmann R, Steinlechner S, Albrecht U, Eichele G, Oster H. Restoration of circadian rhythmicity in circadian clock-deficient mice in constant light. J. Biol. Rhythms 21: 169-176, 2006.

Albrecht U, Eichele G. The mammalian circadian clock. Cur. Opin. Gen. Dev. 13: 271-277, 2003.

Araújo JF, Marques M. Intermodulação de frequências dos ritmos biológicos. In: Marques N, Menna-Barreto L (orgs) Cronobiologia: princípios e aplicações, 3a. ed, São Paulo: Edusp, p. 99-117, 2003.

Arendt D. Evolution of eyes and photoreceptor cell types. Int. J. Dev. Biol. 47: 563-571, 2003.

Assis L, Jerônimo R, Ramos B, Moraes MNCM, Castrucci AML. Ectothermic and endothermic models: A machinery for light and temperature reception based on opsins and TRP channels? In: 9th International Congress of Comparative Physiology and Biochemistry. Krakow, 2015.

Balsalobre A, Damiola F, Schibler U. A serum shock induces circadian gene expression in mammalian tissue culture cells. Cell 93: 929-937, 1998.

Bartell PA, Miranda-Anaya M, Menaker M. Period and phase control in a multioscillatory circadian system (Iguana iguana). J. Biol. Rhythms 19: 47-57, 2004.

Bautista DM, Siemens J, Glazer JM, Tsuruda PR, Basbaum AI, Stucky CL, Jordt SE, Julius D. The menthol receptor TRPM8 is the principal detector of environmental cold. Nature 448: 204208, 2007.

Bellingham J, Chaurasia SS, Melyan Z, Liu C, Cameron MA, Tarttelin EE, Iuvone PM, Hankins MW, Tosini G, Lucas RJ. Evoliution of melanopsin photoreceptors: discovery and characterization of a new melanopsin in nonmammalian vertebrates. Plos Biol. 4(8): 254, 2006.

Bellingham J, Withmore D, Philip AR, Wells DJ, Foster RG. Zebrafish melanopsin: isolation, tissue localization and phylogenetic position. Brain Res. Mol. Brain Res. 107: 128-136, 2002.

Bellono NW, Kammel LG, Zummerman AL, Oancea E. UV light phototransduction activates transient receptor potential A1 ion channels in human melanocytes. Proc. Natl. Acad. Sci. 110: 2383-2388, 2013.

Berson DM, Dunn FA, Takao M. Phototransduction by retinal ganglion cells that set the circadian clock. Science 295: 1070-1073, 2002.

Bouchama A, Knochel JP. Heat stroke. N. Engl. J. Med. 346: 1978-1988, 2002.

Besharse JC, Iuvone PM. Circadian clock in Xenopus eye controlling retinal sertonin Nacetyltransferase. Nature 305(5930): 133-135, 1983.

Binkley S, Kluth E, Menaker M. Pineal function in sparrows: circadian rhythms and body temperature. Science 174(4006): 311-314, 1971. 
Bishnoi M, Kondepudi KK, Gupta A, Karmase A, Boparai RK. Expression of multiple transient receptor potential channel genes in murine 3T3-L1 cell lines and adipose tissue. Pharmacol. Rep. 65(3): 751-755, 2013.

Bozek K, Relógio A, Kielbasa SM, Heine M, Dame C, Kramer A, Herzel H. Regulation of lockcontrolled genes in mammals. Plos One 4: 4882, 2009.

Brown SA, Zumbrunn G, Fleury-Olela F, Preitner N, Schibler, U. Rhythms of mammalian body temperature can sustain peripheral circadian clocks. Curr. Biol. 12: 1574-1583, 2002.

Brown DJ, Brugger H, Boyd J, Paal P. Accidental hypothermia. N. Engl. J. Med. 367: 19301938, 2012.

Buhr ED, Yoo SH, Takahashi JS. Temperature as a universal resetting cue for mammalian circadian oscillators. Science 330: 379-385, 2010.

Buijs RM, van Eden CG, Goncharuk VD, Kalsbeek A. The biological clock tunes the organs of the body: timing by hormones and the autonomic nervous system. J. Endocrinol. 177: 17-26, 2003.

Cahill GM. Clock mechanisms in zebrafish. Cell Tissue Res. 309: 27-34, 2002.

Carr AJ, Whitmore D. Imaging of single light-responsive clock cells reveals fluctuating freerunning periods. Nat. Cell. Biol. 7(3): 319-321, 2005.

Carr AJ, Katherine Tamai T, Young LC, Ferrer, V, Dekens MP, Whitmore, D. Light reaches the very heart of the zebrafish clock. Chronobiol. Int. 23: 91-100, 2006.

Carter-Dawson LD, LaVail MM, Sidman RL. Differential effect of the rd mutation on rods and cones in the mouse retina. Invest. Ophthalmol. Vis. Sci. 17(6): 489-498, 1978.

Caterina MJ, Schumacher MA, Tominaga M, Rosen TA, Levine JD, Julius D. The capsaicin receptor: a heat-activated ion channel in the pain pathway. Nature 389: 816-824, 1997.

Caterina MJ, Leffler A, Malmberg AB, Martin WJ, Trafton J, Petersen-Zeitz KR, Koltzenburg M, Basbaum AI, Julius D. Impaired nociception and pain sensation in mice lacking the capsaicin receptor. Science 288(5464): 306-313, 2000.

Caterina, MJ. Transient receptor potential ion channels as participants in thermosensation and thermoregulation. Am. J. Physiol. Regul. Integr. Comp. Physiol. 292(1): R64-76, 2007.

Cecon E, Flôres DEFL. Regulação da expressão gênica nas engrenagens do relógio circadiano de mamíferos. Rev. Biol. doi: 10.7594/revbio.04.06, 2010.

Chen R, Romero G, Christiansen MG, Mohr A, Anikeeva P. Wireless magnetothermal deep brain stimulation. Science 347(6229): 1477-1480, 2015.

Colburn RW, Lubin ML, Stone DJ, Jr., Wang Y, Lawrence D, D'Andrea MR, Brandt MR, Liu Y, Flores CM, Qin N. Attenuated cold sensitivity in TRPM8 null mice. Neuron. 54: 379-386, 2007.

Cosens DJ, Maning A. Abnormal electroretinogram from a Drosophila mutant. Nature 224: 285-287, 1969. 
Costa A, Castanon-Cervantes O. Daily rhythm of lactate dehydrogenase in rat (Rattus norvegicus) carrying a Per1-luciferase transgene: assessment on serum and liver. Vet. Res. Commun. 29 Suppl 2: 183-186, 2005.

Damiola F, Le Minh N, Preitner N, Kornmann B, Fleury-Olela F, Schibler U. Restricted feeding uncouples circadian oscillators in peripheral tissues from the central pacemaker in the suprachiasmatic nucleus. Genes Dev. 14(23): 2950-2961, 2000.

Davis JB, Gray J, Gunthorpe MJ, Hatcher JP, Davey PT, Overend P, Harries MH, Latcham J, Clapham C, Atkinson K, Hughes SA, Rance K, Grau E, Harper AJ, Pugh PL, Rogers DC, Bingham S, Randall A, Sheardown SA. Vanilloid receptor-1 is essential for inflammatory termal hyperalgesia. Nature 405: 183-187, 2000.

Davies WI, Zheng L, Hughes S, Tamai TK, Turton M, Halford S, Foster RG, Whitmore D, Hankins MW. Functional diversity of melanopsins and their global expression in the teleost retina. Cell Mol. Life Sci. 68(24): 4115-4132, 2011.

Davies WL, Hankins MW, Foster RG. Vertebrate ancient opsin and melanopsin: divergent irradiance detectors. Photochem. Photobiol. Sci. 9: 1444-1457, 2010.

Dickmeis T. Glucocorticoids and the circadian clock. J. Endocrinol. 200: 3-22, 2009.

Dikenson AH. Specific responses of rat raphe neurones to skin temperature. J. Physiol. 273: 277-293, 1977.

Dhaka A, Viswanath V, Patapoutian A. Trp ion channels and temperature sensation. Annu. Rev. Neurosci. 29: 135-161, 2006.

Dhaka A, Murray AN, Mathur J, Earley TJ, Petrus MJ, Patapoutian A. TRPM8 is required for cold sensation in mice. Neuron. 54: 371-378, 2007.

Edery I. Circadian rhythms. Temperatures to communicate by. Science 330: 329-330, 2010.

Edwards, P. A., Muroya, H. \& Gould, R. G. In vivo demonstration of the circadian thythm of cholesterol biosynthesis in the liver and intestine of the rat. J. Lipid. Res. 13: 396-401, 1972.

Farhat FP, Martins CB, Lima LHRG, Isoldi MC, Castrucci AML. Melanopsin and clock genes: regulation by light and endothelin in the zebrafish ZEM-2S cell line. Chronobiol. Intl. 26: 1090-1099, 2009.

Flockerzi V, Nilius B. TRPs: Truly Remarkable Proteins. Handbook Exp. Pharm. 222: 1-12, 2014.

Foster RG, Kreitzman L. Rhythms of Life: The Biological Clocks that Control the Daily Lives of Every Living Thing. 1a. ed, Londres: Profile Books. 288 pp, 2004.

Frigato E, Vallone D, Bertolucci C, Foulks NS. Isolation and characterization of melanopsin and pinopsin expression within photoreceptive sites of reptiles. Naturwissenschaften 93: 379$385,2006$.

Gachon F, Nagoshi E, Brown AS, Ripperger J, Schibler U. The mammalian circadian timing system: from gene expression to physiology. Chromosoma 113(3): 103-112, 2004. 
Garami A, Pakai E, Oliveira DL, Steiner AA, Wanner SP, Almeida MC, Lesnikov VA, Gavva NR, Romanovsky AA. Thermoregulatory phenotype of the Trpv1 knockout mouse: thermoeffector dysbalance with hyperkinesis. J. Neurosci. 31(5): 1721-1733, 2011.

Gaston S, Menaker M. Pineal function: the biological clock in the sparrow? Science 160(3832): 1125-1127, 1968.

Gavva NR, Treanor JJ, Garami A, Fang L, Surapaneni S, Akrami A, Alvarez F, Bak A, Darling M, Gore A, Jang GR, Kesslak JP, Ni L, Norman MH, Palluconi G, Rose MJ, Salfi M, Tan E, Romanovsky AA, Banfield C, Davar G. Pharmacological blockade of the vanilloid receptor TRPV1 elicits marked hyperthermia in humans. Pain 136(1-2): 202-210, 2008.

Gekakis N, Staknis D, Nguyen HB, Davis FC, Wilsbacher LD, King DP, Takahashi JS e Weitz CJ. Role of the CLOCK protein in the mammalian circadian mechanism. Science 280: 15641569, 1998.

Glaser FT, Stanewsky S. Temperature synchronization of the Drosophila circadian clock. Curr. Biol. 15: 1352-1363, 2005.

Golombek DA, Aguilar-Roblero R. Mecanismos de temporização nos vertebrados. In: Marques N, Menna-Barreto L (orgs) Cronobiologia: Princípios e Aplicações, 3a. ed, São Paulo: Edusp, p. 163-190, 2003.

Golombek DA, Rosenstein RE. Physiology of circadian entrainment. Physiol. Rev. 90: 1063$1102,2010$.

Hall JC, Rosbash M. Genetic and molecular analysis of biological rhythms. J. Biol Rhythms 2(3): 153-178, 1987.

Hankins MW, Peirson SN, Foster RG. Melanopsin: an exciting photopigment. Trends. Neurosci. 31: 27-36, 2008.

Hastings JW, Rusak B, Boulous Z. Circadian Rhythms: The Physiology of Biological Timing. Neural and Integrative Physiology. ed. Prosser CL, WileyLiss Inc. 112 p, 1991.

Hazlerigg D. The evolutionary physiology of photoperiodism in vertebrates. Prog. Brain Res. 199, 413-422, 2012.

Hochstrate P. Lanthanum mimicks the trp photoreceptor mutant of Drosophila in the blowfly Calliphora. J. Comp. Physiol. A. 166: 179-187, 1989.

Horta, NAC. Sinalização da Temperatura Corporal Interna para Relógio via Canais TRPV1. Dissertação (Mestrado em Ciências) - Departamento de Fisiologia, Universidade Federal de Minas Gerais, 2015.

Inouye ST e Kawamura H. Persistence of circadian rhythmicity in a mammalian hypothalamic "island" containing the suprachiasmatic nucleus. Proc. Nat. Acad. Sci. USA 76: 5962-5966. 1979.

Isoldi MC, Rollag MD, Castrucci AML, Provencio I. Rhabdomeric phototransduction initiated by the vertebrate photopigment melanopsin. Proc. Nat. Acad. Sci. USA 102: 1217-1221, 2005. 
Iwasaki Y, Tamura Y, Inayoshi K, Narukawa M, Kobata K, Chiba H, Muraki E, Tsunoda N, Watanabe T. TRPV1 agonist monoacylglycerol increases UCP1 content in brown adipose tissue and suppresses accumulation of visceral fat in mice fed a high-fat and high-sucrose diet. Biosci. Biotechnol. Biochem. 75(5): 904-9, 2011.

Klein D, Moore RY, Reppert SM. Suprachiasmatic Nucleus: The Mind's Clock. Oxford: Oxford UP, 431 p, 1991.

Ki Y, Ri H, Lee H, Yoo E, Choe J, Lim C. Warming up your tick-tock: Temperature-dependent regulation of circadian clocks. Neuroscientist 21(5): 503-518, 2015.

Ko CH e Takahashi JS. Molecular components of the mammalian circadian clock. Human Molecular Genetics 15: 271-277, 2006.

Konopka RJ, Benzer S. Clock mutants of Drosophila melanogaster. Proc. Natl. Acad. Sci. USA 68(9): 2112-6, 1971.

Kornmann B, Schaad O, Reinke H, Saini C, Schibler U, Regulation of circadian gene expression in liver by systemic signals and hepatocyte oscillators, Cold Spring Harb. Symp. Quant. Biol. 72: 319-330, 2007.

Koyanagi M, Terakita A. Diversity of animal opsin-based pigments and their optogenetic potential. Biochim. Biophys. Acta. 1837: 710-716, 2014.

Krieger DT. Ventromedial hypothalamic lesions abolish foo-shifted circadian adrenal and temperature rhythmicity. Endocrinology 106: 649-654, 1974.

Krieger, DT, Hauser H e Krey LC. Suprachiasmatic nuclear lesions do not abolish food-shifted circadian adrenal and temperature rhythmicity. Science 197: 398-399, 1977.

Lahiri K, Vallone D, Gondi SB, Santoriello C, Dickmeis T, Foulkes NS. Temperature regulates transcription in the zebrafish circadian clock. Plos Biol. 3: 351, 2005.

Lamia, K. A., Storch, K.-F. \& Weitz, C. J. Physiological significance of a peripheral tissue circadian clock. Proc. Natl. Acad. Sci. USA 105: 15172-7, 2008.

Landgraf D, Tsang AH, Leliavski A, Koch CE, Barclay JL, Drucker DJ, Oster H. Oxyntomodulin regulates resetting of the liver circadian clock by food. eLife 30: 4, 2015.

Lee H, Caterina MJ. TRPV channels as thermosensory receptors in epithelial cells. Pflugers. Arch. 451: 160-167, 2005.

Lee Y, Montell C. Drosophila TRPA1 functions in temperature control of circadian rhythm in pacemaker neurons. J. Neurosci. 33(16): 6716-6725, 2013.

Leliavski A, Dumbell R, Ott V, Oster H. Adrenal clocks and the role of adrenal hormones in the regulation of circadian physiology. J. Biol. Rhythms 30(1):20-34, 2014.

Lehman MN, Silver R, Gladstone WR, Kahn RM, Gibson M, Bittman EL. Circadian rhythmicity restored by neural transplant. Immunocytochemical characterization of the graft and its integration with the host brain. J. Neurosci. 7(6): 1626-1638, 1987.

Lima LHRG, Scarparo AC, Isoldi MC, Visconti MA, Castrucci AML. Melanopsin in chicken melanocytes and retina. Biol. Rhythm. Res. 37: 393-404, 2006. 
Liu Y, Merrow M, Loros JJ, Dunlap JC. How temperature changes reset a circadian oscillator. Science 281: 825-829, 1998.

Lopes GJ, Gois CC, Lima LH, Castrucci AM. Modulation of rhodopsin gene expression and signaling mechanisms evoked by endothelins in goldfish and murine pigment cell lines. Braz. J. Med. Biol. Res. 43: 828-836, 2010.

Ma S, Yu H, Zhao Z, Luo Z, Chen J, Ni Y, Jin R, Ma L, Wang P, Zhu Z, Li L, Zhong J, Liu D, Nilius B, Zhu Z. Activation of the cold-sensing TRPM8 channel triggers UCP1-dependent thermogenesis and prevents obesity. J. Mol. Cell. Biol. 4(2): 88-96, 2012.

Marques MD, Menna-Barreto L. Cronobiologia: Princípios e Aplicações. São Paulo: EDUSP, $42 \mathrm{pp}, 2003$.

Marsch R, Foeller E, Rammes G, Bunck M, Kössl M, Holsboer F, Zieglgänsberger W, Landgraf R, Lutz B, Wotjak CT. Reduced anxiety, conditioned fear, and hippocampal long-term potentiation in transient receptor potential vanilloid type 1 receptor-deficient mice. J. Neurosci. 27: 832-839, 2007.

Menaker M, Tosini G. Beyond Xenopus: Direct demonstration of retinal circadian oscillators in other vertebrates. Inv. Ophthal. Vis. Sci. 37: 66, 1996.

Menna-Barreto L. O tempo na biologia. In: Marques N, Menna-Barreto L (orgs) Cronobiologia: Princípios e Aplicações, 3a. ed, São Paulo: Edusp, p. 25-29, 2003.

Menna-Barreto L, Díez-Nogueira A. External temporal organization in biological rhythms. Biol. Rhythm Res. 43(1): 3-14, 2012.

Mills C, McMackin M, Jaffe R, Yu J, Zininberg E, Slee D, Gogas K, Bradbury M. Effects of the transient receptor potential vanilloid 1 antagonist A-425619 on body temperature and thermoregulation in the rat. Neuroscience 156(1): 165-174, 2008.

Minke B, Wu C, Pak WL. Induction of photoreceptor voltage noise in the dark in Drosophila mutant. Nature 258: 84-87, 1975.

Minke B. Light-induced reduction in excitation efficiency in the trp mutant of Drosophila. J. Gen. Physiol. 79: 361-385, 1982.

Mohawk JA, Green CB, Takahashi JS. Central and peripheral circadian clocks in mammals. Annu. Rev. Neurosci. 35: 445-462, 2012.

Montell C, Rubin GM. Molecular characterization of the Drosophila trp locus: a putative integral membrane protein required for phototransduction. Neuron 2: 1313-1323, 1989.

Moore RY, Eichler VB. Loss of a circandian adrenal corticosterone rhytmin following suprachiasmatic lesions in the rat. Brain Res. 42(1): 201-206, 1972.

Moqrich A, Hwang SW, Earley TJ, Petrus MJ, Murray AN, Spencer KS, Andahazy M, Story GM, Patapoutian A. Impaired thermosensation in mice lacking TRPV3, a heat and camphor sensor in the skin. Science 307: 1468-1472, 2005.

Moraes MNCM, Polettini MO, Ramos BCR, Lima LHGR, Castrucci AML. Effect of light on expression clock genes in Xenopus laevis melanophores. Photochem. Photobiol. 90(3): 696701, 2014a. 
Moraes MNCM, Santos LR, Mezzalira N, Poletini MO, Castrucci AML. Regulation of melanopsins and Perl by $\alpha-\mathrm{MSH}$ and melatonina in photo-sensitive Xenopus laevis melanophores. Biomed. Res. Intl. 10 pages. doi:10.1155/2014/65471, $2014 \mathrm{~b}$.

Moraes MNCM, Mezzalira N, Menaker M, Guler A, Castrucci AML.TRPA1 transcription is altered in the absence of TRPV1: Clock molecular machinery regulation in Mus musculus liver. In: 9th International Congress of Comparative Physiology and Biochemistry. Krakow, 2015.

Nath K, Sarosy JW, Hahn J, Di Como CJ. Effects of ethidium bromide and SYBER Green I on different polymerase chain reaction systems. J. Biochem. Biophys. Methods 42: 15-29, 2000.

Oster H, Damerow S, Hut RA, Eichele G. Transcriptional profiling in the adrenal gland reveals circadian regulation of hormone biosynthesis genes and nucleosome assembly genes. J. Biol. Rhythms 21(5): 350-361, 2006.

Panda S, Provencio I, Tu DC, Pires SS, Rollag MD, Castrucci AMD, Pletcher MT, Sato TK, Wiltshire T, Amdahazy M, Kay SA. Melanopsin is required for non-image-forming photic responses in blind mice. Science 301(5632): 525-527, 2003.

Pevet, P, Challet E. Melatonin: both master clock output and internal time-giver in the circadian clocks network. J. Physiol. Paris 105: 170-182, 2011.

Pittendrigh CS. Circadian systems: entrainment. In Aschoff J: Handbook of Behavioral Neurobiology, Vol4, Biological Rhythms, ed Plenum, New York, 1-29p, 1981.

Pittendrigh CS. Temporal organization: reflections of a Darwinian Clock-Watcher. Annu. Rev. Physiol. 55: 17-54, 1993.

Poletini MO, Ramos BC, Moraes MN, Castrucci AM. Nonvisual opsins and the regulation of peripheral clocks by light and hormones. Photochem. Photobiol. 91(5): 1046-1055, 2015 a.

Poletini MO, Moraes MNCM, Ramos BC, Jerônimo R, Castrucci AML. TRP channels: a missing bond in the entrainment mechanism of peripheral clocks throughout evolution. Temperature, no prelo, $2015 \mathrm{~b}$.

Prolo LM, Takahashi JS, Herzog ED. Circadian rhythm generation and entrainment in astrocytes. J. Neurosci. 25: 404-408, 2005.

Provencio I, Jiang G, deGrip WJ, Hayes WP, Rollag MD. Melanopsin: an opsin in melanophores, brain, and eye. Proc. Natl. Acad. Sci. 95: 340-345, 1998.

Provencio I, Rodrigruez IR, Jiang G, Hayes WP, Moreira EF, Rollag MD. A novel human opsin in the inner retina. J. Neurosci. 20: 600-605, 2000.

Provencio I, Rollag MD, Castrucci AML. Discovery of a photoreceptor net in the mammalian retina. Nature 415: 493, 2002. Commented in Science 295: 955-957, 2002.

Ralph MR, Foster RG, Davis FC, Menaker M. Transplanted suprachiasmatic nucleus determines circadian period. Science 247(4945): 997975-997978, 1990.

Ramos BCR, Moraes MNCM, Poletini MO, Lima LHRG, Castrucci AML. From blue light to clock genes in zebrafish ZEM-2S cells. Plos One 9(9): 1-12, 2014. 
Reddy AB, Karp NA, Maywood ES, Sage EA, Deery M, O'Neill JS, Wong GK, Chesham J, Odell M, Lilley KS, Kyriacou CP, Hastings MH.Circadian orchestration of the hepatic proteome. Curr. Biol. 16: 1107-1115, 2006.

Rensing L, Ruoff P. Temperature effect on entrainment, phase shifting, and amplitude of circadian clocks and its molecular bases. Chronobiol. Int. 19: 807-864, 2002.

Reppert S, Weaver D. Molecular analysis of mammalian circadian rhythms. Annu. Rev. Physiol. 63: 647-676, 2001.

Reppert SM, Weaver DR. Coordination of circadian timing in mammals. Nature 418: 935-941, 2002.

Ribas-Latre A, Baselga-Escudero L, Casanova E, Arola-Arnal A, Salvadó MJ, Bladé C, Arola L. Dietary proanthocyanidins modulate BMAL1 acetylation, Nampt expression and NAD levels in rat liver. Sci. Rep. 5: 10954, 2015.

Richter CP. Biological clocks in medicine and psychiatry: shock-phase hypotesys. Proc. Natl. Acad. Sci. USA 46(11): 1506-1530, 1960.

Richter CP. Sleep and activity: their relation to the 24-hour clock. Proc. Assoc. Res. Nerv. Ment. Dis. 45: 8-27, 1967.

Romanovsky AA. Thermoregulation: some concepts have changed. Functional architecture of the thermoregulatory system. Am. J. Physiol. Regul. Integr. Comp. Physiol. 292: R37-46, 2007.

Ruby NF, Burns DE, Heller HC. Circadian rhythms in the suprachiasmatic nucleus are temperature-compensated and phase-shifted by heat pulses in vitro. J. Neurosci. 19(19): 86308636, 1999.

Rudic RD, McNamara P, Curtis AM, Boston RC, Panda S, Hogenesch JB, Fitzgerald GA. BMAL1 and CLOCK, two essential components of the circadian clock, are involved in glucose homeostasis. Plos Biol. 2(11): 377, 2004.

Sadofsky LR, Sreekrishna KT, Lin Y, Schinaman R, Gorka K, Mantri Y, Haught JC, Huggins TG, Isfort RJ, Bascom CC, Morice AH. Unique responses are observed in transient receptor potential ankyrin 1 and vanilloid 1 (TRPA1 and TRPV1) co-expressing cells. Cells 3(2):616626, 2014.

Saini C, Morf J, Stratmann M, Gos P, Schibler U. Simulated body temperature rhythms reveal the phase-shifting behavior and plasticity of mammalian circadian oscillators. Genes Dev. 26: 567-580, 2012.

Sakamoto K, Nagase T, Fukui H, Horikawa K, Okada T, Tanaka H, Sato K, Miyake Y, Ohara $\mathrm{O}$, Kako K, Ishida N. Multitissue circadian expression of rat period homolog (rPer2) mRNA is governed by the mammalian circadian clock, the suprachiasmatic nucleus in the brain. J. Biol. Chem. 273 (42): 27039-27042, 1998.

Sandu C, Liu T, Malan A, Challet E, Pevet P, Felder-Scmittbuhl MP. Circadian clocks in rat skin and dermal fibroblasts: differential effects of aging, temperature and melatonin. Cell. Mol. Life Sci. 72: 2237-2248, 2015.

Shen WL, Kwon Y, Adegbola AA, Luo J, Chess A, Montell C. Function of rhodopsin in temperature discrimination in Drosophila. Science 331: 1333-1336, 2011. 
Spudich JL, Yang CS, Jung KH. Retinylidene proteins: structures and functions from archea to humans. Annu. Rev. Cell Dev. Biol. 16: 365-392, 2000.

Stephan FK e Zucker I. Circadian rhythms in drinking behavior and locomotor activity of rats are eliminated by hypothalamic lesions. Proc. Nat. Acad. Sci. USA 69: 1583-1586, 1972.

Stokkan KA, Yamazaki S, Tei H, Sakaki Y, Menaker M. Entrainment of the circadian clock in the liver by feeding. Science 291: 490-493, 2001.

Szikszay M, Obal F JR, Obal F. Dose-response relationships in the thermoregulatory effects of capsaicin. Naunyn. Schmiedebergs Arch. Pharmacol. 320(2): 97-100, 1982.

Takumi T, Matsubara C, Shigeyoshi Y, Taguchi K, Yagita K, Maebayashi Y, Sakakida Y, Okamura K, Takashima N, Okamura H. A new mammalian period gene predominantly expressed in the supraquiasmatic nucleus. Genes to Cell 3: 167-176, 1998a.

Takumi T, Taguchi K, Miyake S, Sakakida Y, Takashima N, Matsubara C, Maebayashi Y, Okamura K, Takekida S, Yamamoto S, Yagita K, Yan L, Young MW, Okamura H. A lightindependent oscillatory gene mPer3 in mouse SCN and OVLT. The EMBO J. 17(16): 47534759,1998 b.

Tamai TK, Carr AJ, Whitmore D. Zebrafish circadian clocks: cells that see light. Biochem. Soc. Trans. 33: 962-966, 2005.

Tei H, Okamura H, Shigeyoshi Y, Fukuhara C, Ozawa R, Hirose M, Sakaki Y. Circadian oscillation of a mammalian homologue of the Drosophila period gene. Nature 389: 512-516, 1997.

Terakita A. The opsins. Genome Biol. 6(213): 213.1-213.9, 2005.

Turek FW, Joshu C, Kohsaka A, Lin E, Ivanova G, McDearmon E, Laposky A, Losee-Olson S, Easton A, Jensen DR, Eckel RH, Takahashi JS, Bass J: Obesity and metabolic syndrome in circadian clock mutant mice. Science 308: $1043-1045,2005$.

Vallone D, Gondi SB, Whitmore D, Foulkes NS. E-box function in a period gene repressed by light. Proc. Natl. Acad. Sci. USA 101: 4106-4111, 2004.

Van der Horst GTJ, Muijtjens M, Kobayashi K, Takano R, Kanno S, Takao M, de Wi J, Verkerk A, Eker APM, Dik Van Leenen D, Buijs R, Bootsma D, Hoeijmakers JHJ, Yasui A. Mammalian Cryl and Cry2 are essential for maintenance of circadian rhythms. Nature 398: 627-630, 1999.

Van der Linden AM, Beverly M, Kadener S, Rodriguez J, Wasserman S, Rosbash M, Sengupta P. Genome-wide analysis of light- and temperature-entrained circadian transcripts in Caenorhabditis elegans. Plos Biol. 8: 1000503, 2010.

Vennekens R, Owsianik G, Nilius B. Vanilloid transient receptor potential cation channels: an overview. Curr. Pharm. Des. 14: 18-31, 2008.

Villamizar N, Ribas L, Piferrer F, Vera LM, Sanchez-Vazquez FJ. Impact of daily thermocycles on hatching hythms, larval performance and sex differentiation of zebrafish. Plos One 7(12): 52153, 2012. 
Vitaterna MH, King DP, Chang AM, Kornhouser JM, Lowrey PL, McDonald JD, Dove WF, Pinto LH, Turek FW, Takahashi JS. Mutagenesis and mapping of a mouse gene, Clock, essential for circadian behavior. Science 264: 719-725, 1994.

Voets, T., Talavera, K., Owsianik, G. \& Nilius, B. Sensing with TRP channels. Nat. Chem. Biol. 1: 85-92, 2005.

Vriens J, Nilius B, Voets T. Peripheral thermosensation in mammals. Nat. Rev. Neurosci. 15(9): 573-589, 2014.

Whitmore D, Foulkes NS, Strahle U, Sassone-corsi P. Zebrafish clock rhythmic expression reveal independent peripheral circadian oscillators. Nat. Neurosci. 1(8): 701-707, 1998.

Whitmore D. Light acts on organs and cells in culture to set the vertebrate circadian clock. Nature 404: 87-91, 2000.

Wicks NL., Chan JW, Najera JA, Criello JM, Oancea E. UVA phototransduction drives early melanin synthesis in human melanocytes. Curr. Biol. 21: 1906-1911, 2011.

Yagita K, Tamanini F, van Der Horst GT, Okamura H. Molecular mechanisms of the biological clock in cultured fibroblasts. Science 292(5515): 278-281, 2001.

Yamaguchi S, Mitsui S, Miyake S, Yan L, Onishi H, Yagita K, Suzuki M, Shibata S, Kobayashi $\mathrm{M}$, Okamura $\mathrm{H}$. The 5'-upstream region of mPer1 gene contains two promoters and is responsible for circadian oscillation. Curr. Biol. 10: 873-876, 2000.

Yamashita H, Wang Z, Wang Y, Furuyama T, Kontani Y, Sato Y, Mori N. Impaired basal thermal homeostasis in rats lacking capsaicin-sensitive peripheral small sensory neurons. J. Biochem. 143(3): 385-393, 2008.

Yamazaki S. Resetting central and peripheral circadian oscillators in transgenic rats. Science 5466: 682-685, 2000.

Yoo SH, Yamazaki S, Lowrey PL, Shimomura K, Ko CH, Buhr ED, Siepka SM, Hong HK, Oh WJ, Yoo OJ, Menaker M, Takahashi JS. PERIOD2::LUCIFERASE real-time reporting of circadian dynamics reveals persistent circadian oscillations in mouse peripheral tissues. Proc. Nat. Acad. Sci. USA 101: 5339-5346, 2004.

Yoneshiro T, Saito M. Transient receptor potential activated brown fat thermogenesis as a target of food ingredients for obesity management. Curr. Opin. Clin. Nutr. Metab. Care. 16(6): 625-631, 2013.

Yoshida T, Murayama Y, Ito H, Kageyama H, Kondo T. Nonparametric entrainment of the in vitro circadian phosphorylation rhythm of cyanobacterial KaiC by temperature cycle. Proc. Natl. Acad. Sci. USA 106: 1648-1653, 2009.

Yoshii T, Vanin S, Costa R, Helfrich-Förster C. Synergic entrainment of Drosophila's circadian clock by light and temperature. J. Biol. Rhythms. 24(6): 452-464, 2009.

Young MW, Kay SA. Time zones: a comparative genetics of circadian clocks. Nat. Rev. Genet. 2: 521-526, 2001.

Zanquetta MM, Corrêa-Giannella ML, Monteiro MB, Villares SM. Body wight, metabolism and clock genes. Diabetol. Metab. Syndr. 2: 53, 2010. 
Zhang R, Lahens NF, Balance HI, Hughes ME, Hogenesch JB. A circadian gene expression atlas in mammals: Implications for biology and medicine. Proc. Natl. Acad. Sci. USA. 111(45): 16219-16224, 2014.

Zimmerman NH, Menaker M. The pineal gland: a pacemaker within the circadian system of the house sparrow. Proc. Natl. Acad. Sci. USA 76(2): 999-1003, 1979.

Zordan M, Costa R, Macino G, Fukuhara C, Tosini G. Circadian clocks: what makes them tick? Chronobiol. Int. 17(4): 433-451, 2000.

Zvonic S, Ptitsyn AA, Conrad SA, Scott LK, Floyd ZE, Kilroy G, Wu X, Goh BC, Mynatt RL, Gimble JM. Characterization of peripheral circadian clocks in adipose tissues. Diabetes 55(4): 962-970, 2006.

Zylka MJ, Shearman LP, Weaver DR, Reppert SM. Three period homologs in mammals: differential light responses in the suprachiasmatic circadian clock and oscillating transcripts outside of brain. Neuron. 20: 1103-1110, 1998. 